Universidade de São Paulo

Instituto de Biociências

\title{
Vanessa Simões
}

Sinalização redox na diferenciação osteogênica

São Paulo

2016 
Universidade de São Paulo

Instituto de Biociências

\section{Vanessa Simões}

\section{Sinalização redox na diferenciação osteogênica}

\section{Redox signaling in osteogenic differentiation}

Dissertação apresentada ao Instituto de Biociências da Universidade de São Paulo, para a obtenção de Título de Mestre em Ciências, na Área de Biologia - Genética.

Orientador: Prof. Dr. Luis Eduardo Soares Netto

São Paulo

2016 


\section{Ficha Catalográfica}

Simões, Vanessa

"Sinalização redox na diferenciação osteogênica"

101 Páginas

Dissertação (mestrado) - Instituto de Biociências da Universidade de São Paulo.

Departamento de Genética e Biologia Evolutiva.

1. Sinalização Redox; 2. Peroxirredoxinas; 3. Diferenciação celular.

I. Universidade de São Paulo, Instituto de Biociências. Departamento de Genética e Biologia Evolutiva.

\section{Comissão Julgadora}

$\operatorname{Prof}(a) . \operatorname{Dr}(a)$.

$\operatorname{Prof}(a) . \operatorname{Dr}(a)$.

Prof. Dr. Luis Eduardo Soares Netto

Orientador 
Ao meus pais. 
"Sempre permaneça aventureiro. Por nenhum momento se esqueça de que a vida pertence aos que investigam. Ela não pertence ao estático; Ela pertence ao que flui. Nunca se torne um reservatório, sempre permaneça um rio." 


\section{Agradecimentos}

Ao Professor Dr Luis Eduardo Soares Netto, pelo acolhimento, oportunidade, orientação e por ter aceitado o desafio de desenvolver esse projeto. Sua competência e dedicação à Ciência são exemplo a todos que desejam crescer como cientistas.

À Professora Dra Maria Rita Passos-Bueno, pela disponibilização irrestrita de seu laboratório, fundamental para o desenvolvimento deste projeto, pelos conselhos e ajuda durante todo 0 período deste projeto.

Ao CNPq e FAPESP pelo suporte financeiro.

Ao Professor Dr Francisco Laurindo, pela disponibilização de material e discussões sobre HyPer e NOX.

À Professora Dra Lygia da Veiga Pereira, pelas ótimas sugestões na minha qualificação e por disponibilizar o laboratório para cultivo de células-tronco embrionárias de camundongos. Ao $\mathrm{Dr}$ Luis Farinha, pela paciência e ajuda no cultivo dessas células, bem como pelas discussões sobre metodologias e ciência em geral.

À Dra Denise Fernandes, do Incor-USP, pela ajuda com PEGs, catalase e outros protocolos.

À Prof Dra Luciane Capello, da Unifesp, por toda ajuda na concepção inicial deste projeto, bem como padronizações, dicas e pelas conversas científicas e sobre a vida.

Ao Dr Marcel Liberman, pelas dicas sobre transfecção de células.

Aos funcionários da Seção de Pós-Graduação do IB-USP, sempre dispostos a ajudar no que fosse necessário, em especial à Shirlene Fernandes, por ser tão competente.

Aos amigos do Lab 328 (Laboratório de Genética e Biologia Molecular de Antioxidantes e Radicais livres ou Laboratório de Biologia Redox ou Laboratório de Proteínas e Biologia Redox, que seja), pelo bom convívio, ótimas discussões científicas e risadas garantidas. Em especial, ao Thiago Alegria, por toda a ajuda, discussões, Westerns e bom humor, à Renata, pela amizade, pelos dias de abrigo e MasterChef, ao Diogo, por toda a disponibilidade, ajuda e pelas Gambiarras, à Anita, por ser muito querida e pela conversa no último dia da SBBq (nunca vou esquecer) e também ao Fernando, Flávio, Renato, Sushi, Cris, Andressa, Simone, Valesca, Jonas, Julia e Rogério.

Ao pessoal do Lab 200, uma turma muito competente, divertida e maluca, pelo acolhimento e por toda a ajuda e paciência. Em especial, a Simone Ferreira, que me ensinou cultura de células, ao Lucas Opê, meu querido irmãozinho mais novo, à Carol Malcher, por todo o apoio, encorajamento e conversas em momentos difíceis, ao Gerson, pelo ótimo humor, pela ajuda com qPCR e críticas a western blot, ao Luciano, pela companhia, trollagem e treinos de corrida e ao Roberto, pelas discussões intermináveis, críticas generalizadas, mas também por todo o cuidado, atenção, amizade, oportunidades que me ofereceu e por ter revisado cuidadosamente essa dissertação. 
Aos colegas do Laboratório de Bioquímica do Instituto Butantan, Dra Marilene Demasi, Janaína, Erina e Adrian, pelas discussões e ajudas durante os seminários de grupo.

Ao Doutor Gustavo, pela amizade, ensinamentos e discussões científicas desde a IC, pelos momentos de diversão e também de conversas sérias, por todas as oportunidades que me ofereceu para crescer pessoal e profissionalmente (e conhecer adoráveis praças), e pelo auxílio na elaboração dessa dissertação.

Às amizades que começaram na faculdade, mas que levarei por toda a vida, em especial à Day, Lari, Micca e Natany. Obrigada pelas risadas, festas, viagens, galhos quebrados, carinho, ensinamentos e paciência. Vocês são mulheres incríveis, de personalidades tão diferentes, mas que eu admiro e amo com a mesma intensidade.

Aos amigos e colegas da turma 08N (em especial, meu Grupo Burro) pelo bom convívio, discussões, festas, encontros e momentos de muita diversão e aprendizado. Aos queridos que fizeram minha licenciatura ter momentos adoráveis, Tama, Rafa e Bibi.

Ao pessoal do Games \& Birinights, Tama, Xano, Lu, Karina e Rafa, por todas as comidinhas deliciosas e gargalhadas garantidas.

Aos amigos da Locus, que trouxeram mais movimento e graça a minha vida. Em especial, ao Gilmar Judas e às minhas queridas Marcela e Shirley, por todas as caronas, forrós, sambas, cafés, bolos, açaí, bandejão, abrigo, conversas, risadas e apoio incondicional.

Aos amigos de mais de uma década, Marcelo e Thais, por todo carinho, companheirismo, ajuda, conselhos... Vocês são essenciais a minha vida. E também ao Lucão, que nunca esquece meu aniversário e ao Johann e à Nai, por fazerem meus amigos felizes.

À minha querida Milena, por quase 20 anos de amizade, apoio, conversas, carinho e por agora fazer parte da minha família.

Ao pessoal da R-Crio, pelo convívio agradável e boas risadas. Em especial ao Walker, Cláudio e Natália, pela confiança no meu trabalho, por toda a paciência e por estarem empenhados em me ajudar nessa nova fase.

Aos meus tios e primos, que sempre me proporcionaram as festas de famílias mais acolhedoras, divertidas e deliciosas.

Aos meus avós Nair e Célio, que não se deixaram endurecer pela vida difícil que tiveram, por todo carinho e apoio. À vó Ivone e vô Edegar, que além disso, deixaram na minha memória os melhores momentos da infância. E à Dona Ana, por estar cuidando com tanta dedicação do meu avô.

À minha irmã Vivi, que me fez aprender a ter paciência e tolerância, pela confiança e admiração, e por sempre me lembrar qual é minha essência, de onde eu vim e para onde eu sempre vou voltar.

À minha mãe Márcia e meu pai Márcio, a quem devo tudo. Eles que sempre confiaram em mim e nas minhas escolhas e sempre se dedicaram ao máximo para que eu tivesse as oportunidades que eles nunca tiveram. 


\section{Sumário}

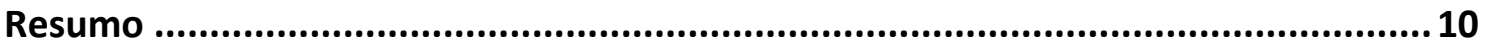

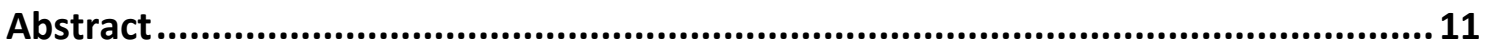

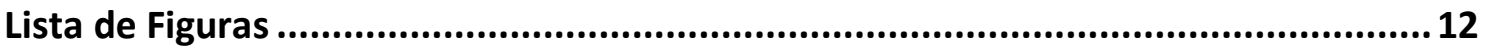

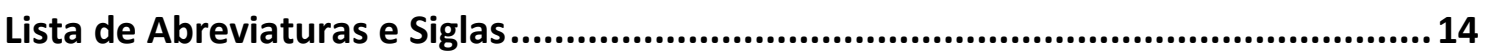

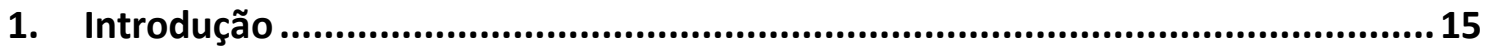

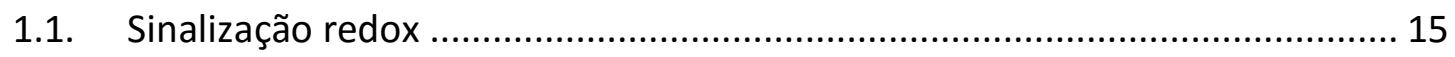

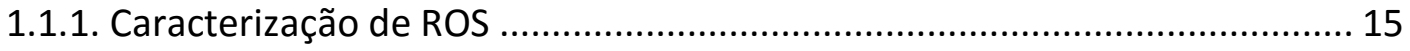

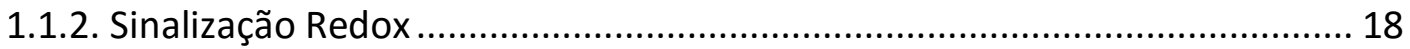

1.1.3. Peroxirredoxinas na sinalização redox celular ....................................... 20

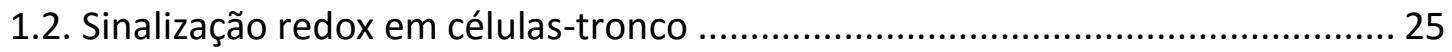

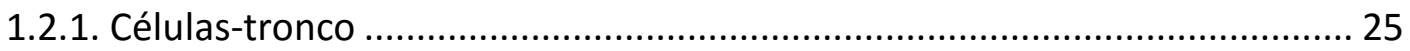

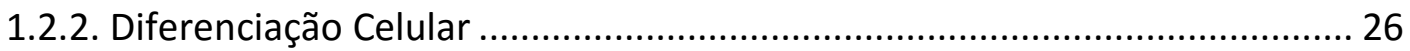

1.2.3. Metabolismo energético na diferenciação celular ...................................... 27

1.2.4. Controle redox da diferenciação celular .................................................. 29

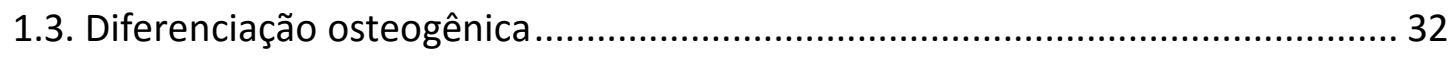

1.3.1. Formação e reabsorção óssea.................................................................. 32

1.3.2. Etapas da diferenciação de osteoblastos ................................................ 32

1.3.3. Sinalização celular na diferenciação osteogênica ........................................ 33

1.3.4. A importância da sinalização redox na diferenciação osteogênica .............. 36

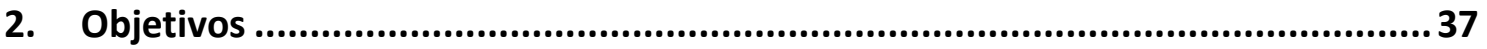

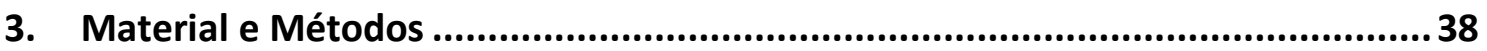

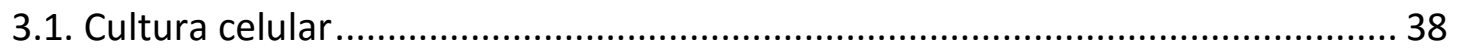

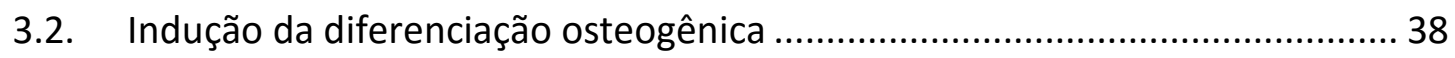

3.3. Marcação de matriz extracelular mineralizada por Alizarin Red..................... 38 


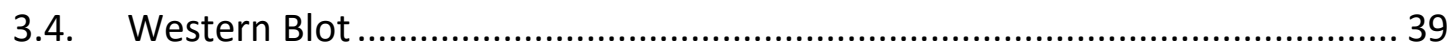

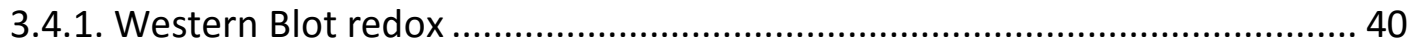

3.5. Preparo dos reagentes de tratamento ..................................................... 40

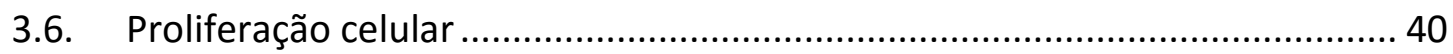

3.7. Ensaio de Unidades Formadoras de Colônia ................................................ 41

3.8. Dosagem de peróxido de hidrogênio com Amplex Red .................................. 42

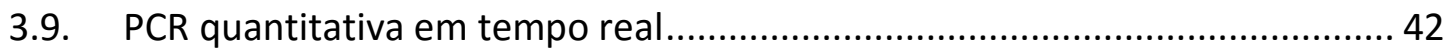

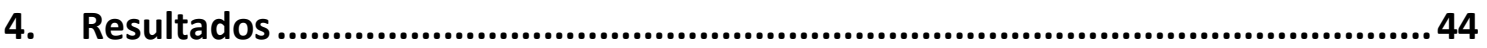

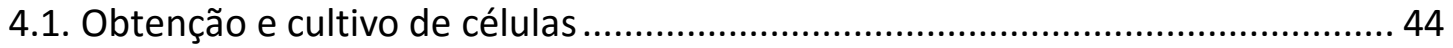

4.2. Diferenciação osteogênica.............................................................................. 45

4.3. Efeitos de tratamentos redox na diferenciação osteogênica ............................... 51

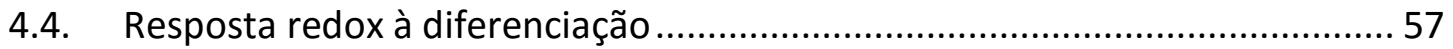

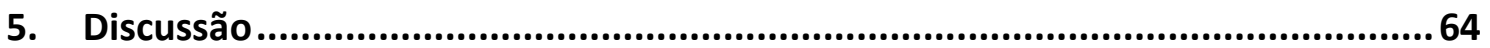

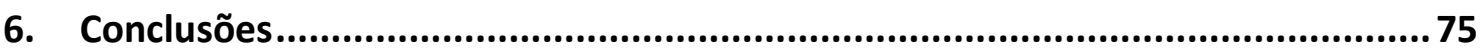

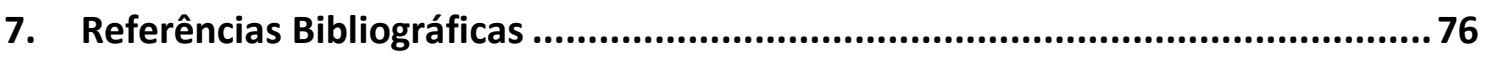

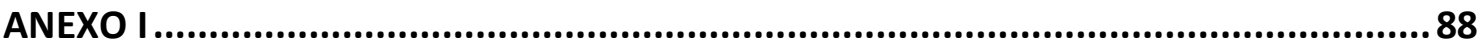




\section{Resumo}

Mecanismos redox estão envolvidos em diversos processos, como sobrevivência, proliferação e diferenciação celular, pela modulação da atividade de quinases, fosfatases e fatores de transcrição, entre outros, através da modificação oxidativa e reversível de resíduos de cisteína. Neste trabalho, nós estudamos processos redox subjacentes a diferenciação osteogênica induzida por BMP2, utilizando linhagens de células MC3T3-E1. Nosso objetivo foi investigar modificações redox como possíveis moduladores do processo de diferenciação osteogênica. Para isso, nós primeiramente caracterizamos a diferenciação osteogênica nas células MC3T3-E1 após o tratamento com BMP2, através da expressão do marcador osteogênico Osteocalcina, da fosforilação do complexo Smad 1/5/8 e da deposição de matriz extracelular calcificada. Análises de expressão gênica por qPCR mostraram que o tratamento com BMP2 resultou no aumento de expressão de NOX4, o que provavelmente leva ao aumento na produção de peróxido de hidrogênio intracelular. Nós investigamos também a modulação de peroxiredoxinas nesse processo e análises de expressão gênica mostraram que não há alterações nos níveis de expressão de Prx1 e 2 durante a diferenciação, mas os ensaios de western blot redox indicam que a Prx1 pode ser oxidada após o tratamento com BMP2, de maneira dose dependente. Outras análises in vitro mostram que células expostas a $\mathrm{N}$ acetilcisteína (NAC) e PEG-catalase apresentam diferenciação osteogênica prejudicada, detectada por baixos níveis de deposição de matriz extracelular calcificada, comparado com células não-tratadas. Além disso, a fosforilação de Smad 1/5/8 são reduzidas nessas condições. Nossos dados sugerem que processos redox podem modular a sinalização celular durante o processo de diferenciação osteogência. 


\section{Abstract}

Redox mechanisms are involved in several processes, such as cell survival, proliferation and differentiation, among other ways by modulating kinases, phosphatases and transcription factors activity that can occur through reversible and oxidative modification of cysteine residues. We were interested in studying redox processes underlying osteogenic differentiation induced by BMP-2, using MC3T3-E1 cell lineage. Our objective was to investigate redox modifications as possible modulators of the osteogenic differentiation process. We first characterized osteogenic differentiation in MC3T3-E1 cells upon BMP2 treatment, through gene expression of the osteogenic marker Osteocalcin, Smad $1 / 5 / 8$ (belonging to the BMP-2 pathway) protein phosphorylation and extracellular matrix calcification. Gene expression analysis by qPCR showed that BMP2 treatment resulted in NOX4 upregulation, which probably also leads to hydrogen peroxide production. We have investigated peroxiredoxin modulation in this process, and gene expression analysis shows no significant change in peroxiredoxin 1 and 2 expression levels, but redox western blotting assays indicate that Prx1 can be oxidized after BMP2 treatment, in a dose dependent manner. In vitro analysis shows that cells exposed to N-acetyl-L-cysteine (NAC) and PEG-catalase display impaired osteogenic differentiation, detected by lower levels of calcified extracellular matrix deposition compared with non-treated cells. Moreover, phosphorylation of Smad $1 / 5 / 8$ complex is reduced under these redox treatments. Our data suggest that redox pathways can modulate cell signaling during the osteogenic differentiation process. 


\section{Lista de Figuras}

Figura 1. Possíveis efeitos da oxidação de cisteínas em proteínas. ..........................................19

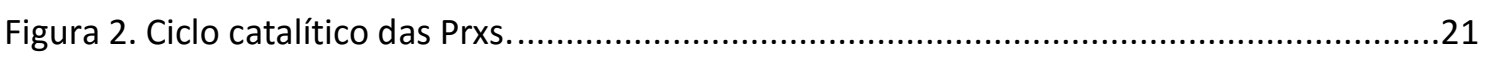

Figura 3. Mecanismos de regulação de proteínas por peróxido de hidrogênio via Prx..............25

Figura 4. Autorrenovação e diferenciação em células-tronco. ..................................................26

Figura 5. Regulação da função de células-tronco pelo metabolismo. .......................................29

Figura 6. Etapas da diferenciação osteogênica......................................................................33

Figura 7. Principais vias relacionadas a diferenciação osteogênica............................................34

Figura 8. Marcação com Alizarin Red durante a diferenciação oestegênica de MC3T3-E1. .......45

Figura 9. Diferenciação osteogênica com diferentes concentrações de ácido ascórbico............46

Figura 10. Ativação da via de BMP após o tratamento com BMP2. ........................................48

Figura 11. Expressão de osteocalcina após indução da diferenciação osteogênica ...................49

Figura 12. Tratamento com concentrações crescente de hr BMP2 e marcação de matriz

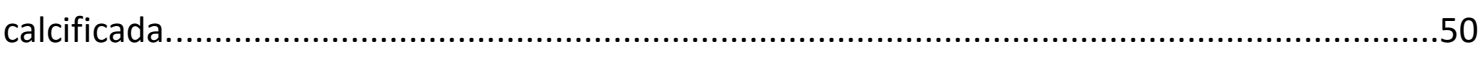

Figura 13. Diferenciação osteogênica em células tratadas com NAC e peróxido de hidrogênio.

Figura 14. Efeito dos tratamentos com oxidantes e antioxidantes na sobrevivência e proliferação

celular. .53

Figura 15. Marcação de catalase intracelular após tratamento com PEG-catalase ......................55

Figura 16. Diferenciação celular após tratamento com PEG-catalase. ......................................55

Figura 17. Fosforilação de Smad 1/5/8 após tratamentos com oxidantes e antioxidantes ........57

Figura 18. Quantificação de peróxido de hidrogênio após tratamento com BMP2 2....................59

Figura 19. Expressão relativa de NOX4 em células MC3T3-E1 após estímulo osteogênico........60

Figura 20. Expressão relativa de Prdx1 e Prdx2 em células MC3T3-E1 após estímulo osteogênico. 
Figura 21. Western blot anti-peroxiredoxina 1.

Figura 22. Modelo da atuação de NAC e catalase em vias bioquímicas. .

Figura 23. Possíveis modelos para a participação de oxidantes na diferenciação osteogênica..71 


\section{Lista de Abreviaturas e Siglas}

\begin{tabular}{|c|c|}
\hline BMP & Bone Morphogenetic Protein \\
\hline BMPR-I & Receptor de BMP tipo I \\
\hline BMPR-II & Receptor de BMP tipo II \\
\hline Cat. & Catalase \\
\hline CysP & Cisteína peroxidásica \\
\hline Duox & Dual oxidase \\
\hline ESC & Célula-tronco embrionária \\
\hline GR & Glutationa redutase \\
\hline GSH & Glutationa reduzida \\
\hline hr BMP2 & BMP2 recombinante humana \\
\hline HSC & Célula-tronco hematopoiética \\
\hline iPSC & Célula-tronco pluripotente induzida \\
\hline $\mathrm{mESC}$ & Célula-tronco embrionária de camundongo \\
\hline MSC & Célula-tronco mesenquimal \\
\hline NAC & N-acetylcysteine \\
\hline NEM & N-ethylmaleimide \\
\hline NOX & NADPH oxidase \\
\hline NOX4 & NADPH oxidase isoforma 4 \\
\hline OC & Osteocalcina \\
\hline PEG & Polyethylene glycol \\
\hline $\operatorname{Prx}$ & Peroxirredoxina \\
\hline qPCR & PCR quantitativa em tempo real \\
\hline ROS & Reactive oxygen species (Espécies reativas de oxigênio) \\
\hline SOD & Superóxido dismutase \\
\hline Srx & Sulfirredoxina \\
\hline TCA & Trichloroacetic Acid \\
\hline TGF- $\beta$ & Transforming Growth Factor 8 \\
\hline $\operatorname{Trx}$ & Tiorredoxina \\
\hline
\end{tabular}




\section{Introdução}

Esta dissertação explora o papel de moléculas oxidantes durante o processo de diferenciação celular. Investigamos a importância dessas moléculas no contexto de sinalização celular e a via de diferenciação osteogênica, cujo potencial de modulação por tais moléculas ainda não é bem conhecido. Esses dois temas são muito bem estudados em suas áreas, mas ainda contam com poucos trabalhos que os interrelacionam.

\subsection{Sinalização redox}

O conceito de sinalização redox começou a ganhar força nas últimas duas décadas, e refere-se ao papel de moléculas oxidantes em vias de transdução de sinais intracelulares. Nesta seção, vamos caracterizar as principais moléculas, suas fontes e as vias influenciadas por espécies reativas de oxigênio, bem como as principais hipóteses do funcionamento da sinalização redox nas células. Essa contextualização é útil para entendermos como as espécies reativas de oxigênio podem ser importantes na manutenção e diferenciação celular.

\subsubsection{Caracterização de ROS}

O metabolismo aeróbico gera uma série de subprodutos reativos. Espécies reativas de oxigênio (ROS - Reactive Oxygen Species) é um termo utilizado para designar moléculas que são mais reativas do que o oxigênio livre. Deve-se ter em mente que "ROS" é um termo vago e que abrange um conjunto de moléculas com propriedades físico-químicas distintas, sendo sempre desejável, quando possível, especificarmos a qual molécula estamos nos referindo (Forman et al., 2015). Alguns exemplos de ROS 
encontradas nas células são ânion radical superóxido $\left(\mathrm{O}_{2}{ }^{\circ-}\right)$, peróxido de hidrogênio $\left(\mathrm{H}_{2} \mathrm{O}_{2}\right)$ e radical hidroxila $\left({ }^{\circ} \mathrm{OH}\right)$, que podem ser produzidas como consequência do próprio metabolismo celular, pela redução parcial do $\mathrm{O}_{2}$, ou ainda estimuladas por fatores externos, como radiação ionizante, fármacos, substâncias tóxicas, entre outros (Fridovich, 1975; Kobayashi e Suda, 2012). Uma característica comum entre os diferentes tipos de ROS é a sua capacidade de causar modificações oxidativas (direta ou indiretamente) em proteínas, DNA e lipídeos, capazes de alterar sua estrutura e função (Apel e Hirt, 2004).

Com relação à sua produção, as principais fontes intracelulares de ROS são a cadeia de transporte de elétrons mitocondrial (Boveris e Cadenas, 1975) e o complexo NADPH oxidase ligado à membrana plasmática (Babior, 2000; Vignais, 2002). Outras fontes celulares de ROS incluem uma série de outras enzimas intracelulares, como xantina oxidase, ciclooxigenases, citocromo P450 e lipoxigenases, que produzem oxidantes como parte de sua função enzimática normal (Finkel, 2011). Cada uma dessas fontes pode ser ativada em diferentes contextos celulares e como resposta a diversos estímulos, incluindo a fatores de crescimento e diferenciação, embora os mecanismos desta ativação ainda não sejam totalmente descritos.

A mitocôndria é amplamente conhecida como o principal sítio de produção intracelular de oxidantes. A maioria das evidências sugere que os oxidantes mitocondriais são formados predominantemente no complexo I ou no complexo III da cadeia de transporte de elétrons, quando elétrons derivados de $\mathrm{NADH}$ ou $\mathrm{FADH}_{2}$ reagem com $\mathrm{O}_{2}$ e produzem ânion superóxido.

A segunda fonte mais importante de produção de oxidantes é o complexo NADPH oxidase (NOX), que catalisa a redução de oxigênio, utilizando NADPH como 
doador de elétrons. Diferente de outras fontes de ROS descritas acima, o produto principal das reações catalisadas por NOX são o radical ânion superóxido ou peróxido de hidrogênio, o que implica fortemente essas moléculas com papel de sinalização.

Já foram descritos sete membros da família das NOX (Nox1-5 e Duox1-2), que são conservadas evolutivamente (Brown e Griendling, 2009; Aguirre e Lambeth, 2010). Todos os membros da família NOX são proteínas transmembranas com propriedades estruturais e funcionais semelhantes, contendo ao menos seis domínios transmembrana e dois domínios citosólicos que ligam FAD e NADPH (Bedard e Krause, 2007; Brown e Griendling, 2009). A NOX2 foi a primeira isoforma caracterizada e tem sido reconhecida como a fonte de ROS para "burst oxidativo" nos fagócitos, responsáveis pela defesa contra patógenos (Van Der Vliet, 2008; Robinson, 2009). Mais recentemente, outras isoformas de NOX foram descritas em diversos tipos celulares, produzindo radical ânion superóxido ou peróxido de hidrogênio que participam de vias de sinalização (Cheng et al., 2001; Arbiser et al., 2002; Brown e Griendling, 2009).

Além da produção, os níveis de ROS são regulados através de um grande repertório de enzimas antioxidantes, incluindo superóxido dismutases (SODs), glutationa peroxidase (GPx), glutationa redutase (GR), peroxirredoxinas (Prxs), tiorredoxina (Trx) e catalase, capazes de decompor radical ânion superóxido ou peróxido de hidrogênio (Pervaiz, Taneja e Ghaffari, 2009). Quando as ROS escapam desses mecanismos de detoxificação, podem atingir biomoléculas e causar alterações oxidativas, que podem conduzir a mudanças nas funções biológicas e, às vezes, provocar injúria celular (Foster et al., 2009). Por outro lado, muitas evidências têm mostrado que organismos aeróbicos não apenas desenvolveram mecanismos de defesa contra as ROS, mas que diversas vias de transdução de sinal que regulam proliferação e sobrevivência 
celulares, com a participação de oxidantes, foram selecionadas ao longo da evolução (Sattler et al., 1999; Chen e Pervaiz, 2007; D'autréaux e Toledano, 2007; Kobayashi e Suda, 2012). Essas evidências reforçam uma área de estudo muito promissora dentro da Biologia Redox, a Sinalização Redox, que certamente trará avanços científicos importante ao ser melhor explorada e descrita.

\subsubsection{Sinalização Redox}

Por muitos anos, a visão tradicional sobre ROS era de que sua produção seria um subproduto danoso do metabolismo celular, sem um mecanismo de regulação refinado, e que seus alvos intracelulares seriam aleatórios. A oxidação indiscriminada de lipídeos, proteínas e DNA por ROS causaria o acúmulo de biomoléculas danificadas e a presença dessas moléculas era considerada uma potencial contribuição para uma série de patologias, incluindo doenças neurodegenerativas, aterosclerose e para o processo de envelhecimento (Holmström e Finkel, 2014). Embora historicamente vistas apenas como moléculas que provocam lesões, evidências recentes sugerem que ROS podem atuar como reguladores de vias de sinalização intracelular.

Os mecanismos de sinalização redox são baseados principalmente em modificações de resíduos de cisteína específicos, encontrados em proteínas alvo redoxsensíveis. Mais especificamente, a oxidação desses resíduos de cisteína pode formar um ácido sulfênico (-SOH), que por sua vez, pode formar uma ponte dissulfeto com cisteínas vizinhas (-S-S-) ou sofrer novas oxidações para ácido sulfínico $\left(-\mathrm{SO}_{2} \mathrm{H}\right)$ ou sulfônico ($\left.\mathrm{SO}_{3} \mathrm{H}\right)$. Com exceção do ácido sulfônico e em menor grau o ácido sulfínico, essas modificações redox são reversíveis, através de sistemas redutores como tiorredoxinas, 
o que é mais uma evidência que essas modificações atuam como sensor e sinalização redox (Roos e Messens, 2011; Ray, Huang e Tsuji, 2012).

A oxidação de resíduos de cisteína pode levar a modificação reversível da estrutura ou função de uma proteína (Fig. 1). Os efetores celulares sensíveis a modulação redox são, por exemplo, quinases, fosfatases e fatores de transcrição (Conrad et al., 2010; Ostman et al., 2011; Holmström e Finkel, 2014). Existem na literatura diversas descrições de células estimuladas com fatores de crescimento, como EGF, PDGF e outros, que respondem com aumento da produção de peróxido de hidrogênio, que inativa (de maneira reversível) proteínas tirosina-fosfatases, por exemplo, o que permite que cascatas de fosforilação se propaguem dentro da célula (Sundaresan et al., 1995; Lee et al., 1998; Rhee et al., 2000; Giannoni et al., 2005; Tonks, 2005).

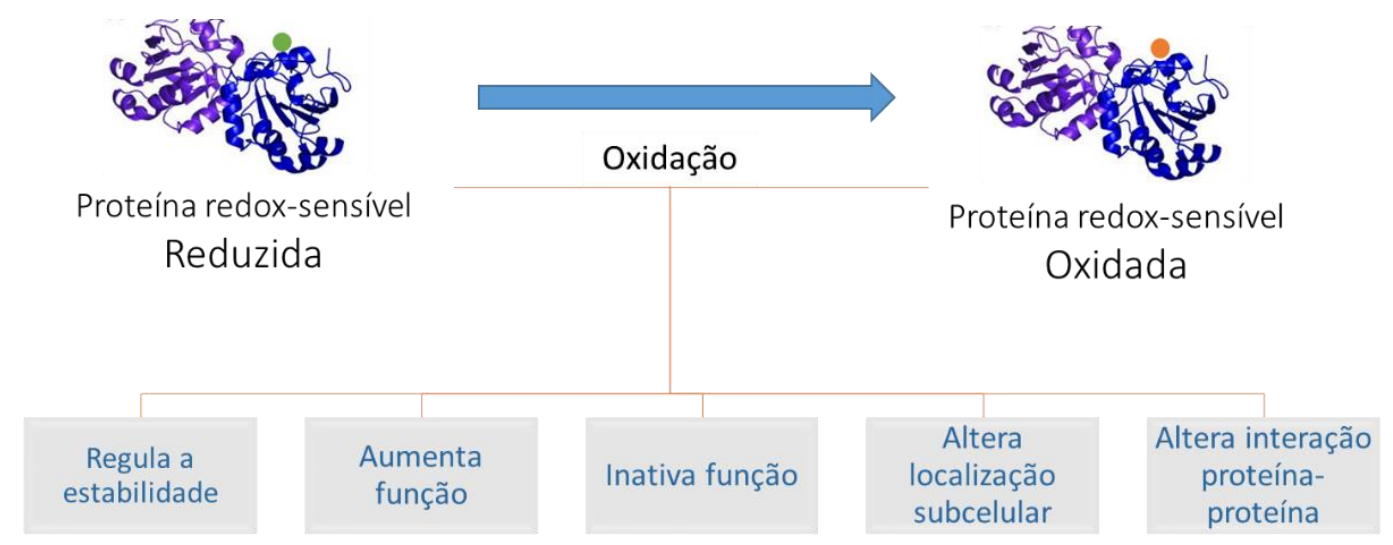

Figura 1. Possíveis efeitos da oxidação de cisteínas em proteínas. Representação de um resíduo de cisteína hipotética (reduzida - verde) em uma proteína, passível de sofrer oxidação (oxidada - laranja). A oxidação de um resíduo de cisteína leva a alterações em alvos redox-sensíveis que podem ter efeitos na estabilidade, conformação, atividade, localização e interação proteína-proteína. Modificado de Holmström e Finkel, 2014.

Embora muitos esforços estejam sendo realizados para esclarecer os efeitos gerais das ROS na transdução de sinal em células, pouco é conhecido sobre os 
mecanismos de sinalização redox, inclusive como as reações de óxido-redução prosseguem ao longo da via (Netto et al., 2016). Nesse contexto de sinalização redox, para que o peróxido de hidrogênio possa servir como um sinal, através da modificação direta ou indireta de proteínas sinalizadoras, sua concentração deve aumentar rapidamente e de maneira localizada. Isso porque o peróxido de hidrogênio produzido pelo metabolismo basal é removido muito eficientemente das células por diversas proteínas, principalmente as peroxiredoxinas.

Várias isoformas das Prx são abundantes no citosol e possuem alta reatividade com peróxido de hidrogênio, eliminando-o de maneira muito eficiente e impedindo que ele reaja com outras moléculas (Chae et al., 1999; Winterbourn, 2008; Winterbourn e Hampton, 2008; Hall et al., 2011). Por este motivo, a regulação da atividade das Prx tem recebido crescente atenção não só como defesa antioxidante, mas também em processos de sinalização celular (Winterbourn e Hampton, 2008). Como Prx reagem rapidamente e especificamente com peróxido de hidrogênio, é muito provável que essas enzimas atuem como sensores desse oxidante (Rhee et al., 2012). Compreender o papel das Prx nesse contexto é essencial para que possamos conciliar os dados biológicos, que trazem a importância de oxidantes na biologia celular, juntamente com os dados químicos, sobre os parâmetros cinéticos de reatividade desses oxidantes com diversas proteínas.

\subsubsection{Peroxirredoxinas na sinalização redox celular}

Inicialmente isoladas em leveduras, (Kim et al., 1988; Chae, Chung e Rhee, 1994; Netto et al., 1996), as peroxirredoxinas (Prxs) são peroxidases com atividade baseada em resíduo de cisteína (tiol-peroxidases), capazes de reduzir e detoxificar peróxido de 
hidrogênio, peroxinitrito e uma grande variedade de hidroperóxidos orgânicos (-ROOH) (Bryk, Griffin e Nathan, 2000; Peshenko e Shichi, 2001; Hofmann, Hecht e Flohé, 2002). O mecanismo básico pelo qual esses sistemas atuam envolve a transferência de elétrons das enzimas para seus substratos, acarretando na redução do substrato e oxidação da enzima. As enzimas são recicladas e voltam ao seu estado reduzido graças a elétrons provenientes do NADPH, passando por outras enzimas intermediárias.

O ciclo catalítico das Prxs envolve cinco reações principais: (1) peroxidação, (2) resolução, (3) redução de dissulfeto, (4) hiperoxidação e (5) redução de ácido sulfínico. A etapa de redução de ácido sulfínico por Sulfiredoxina (Srx) é relevante apenas para algumas enzimas da subfamilia Prx1, que geralmente são as mais expressas em eucariotos (Fig. 2).

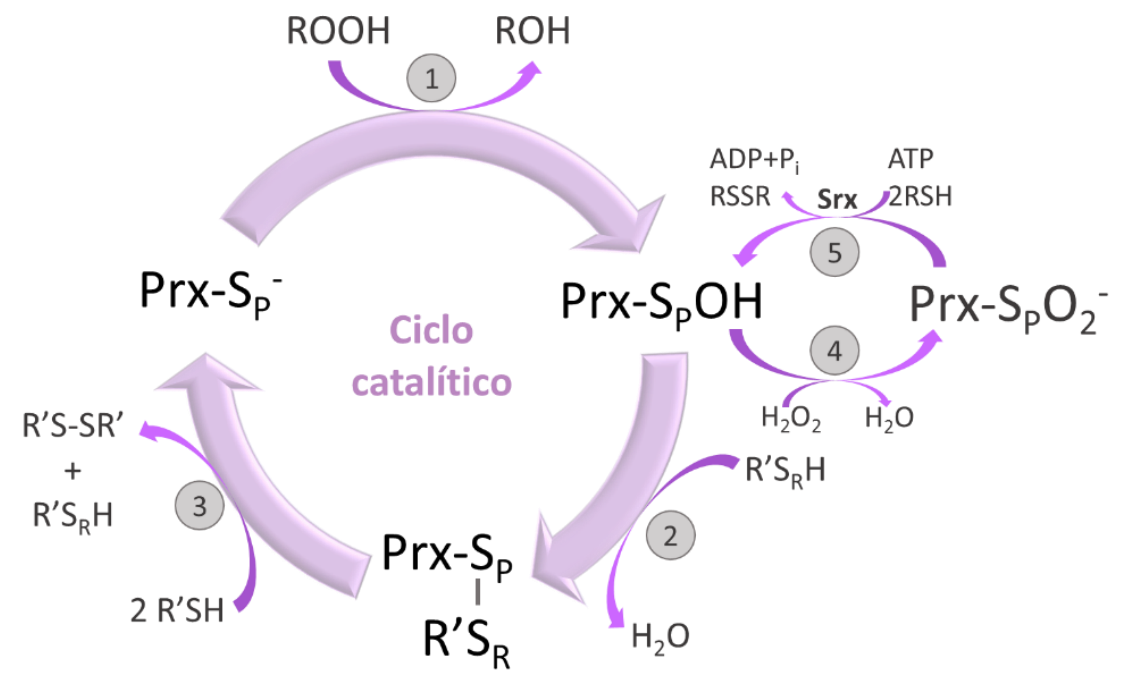

Figura 2. Ciclo catalítico das Prxs. Cinco etapas do ciclo catalítico das Prxs, considerando a redução de uma (reações 1 a 3) ou duas (reações 1 a 5) moléculas de peróxido. Sp - Cisteína peroxidásica; $S_{R}$ - Cisteína de resolução. Modificado de Karplus, 2015.

Quando a cisteína peroxidásica da Prx passa para estado de ácido sufínico, a proteína fica inativa, de maneira reversível, até ser reduzida por Srx, com alto gasto de ATP. Essa condição de inativação por superoxidação pode ocorrer na presença de altas 
concentrações de peróxido de hidrogênio, portanto, compreender e analisar esse estado é importante no contexto da sinalização redox.

As células de mamíferos expressam seis isoformas de Prxs, distribuídas no citosol, mitocôndria, retículo endoplasmático e peroxissomo (Rhee et al., 2012). Essas subfamílias apresentam sequências de aminoácidos diferentes entre si, mas todas possuem em comum um resíduo de cisteína conservado no sítio ativo, denominada cisteína peroxidásica (CysP) que é responsável direto pela redução do peróxido (Wood et al., 2003; Rhee, Chae e Kim, 2005; Fourquet et al., 2008).

Diversos membros da família das Prxs atuam não apenas como antioxidantes, mas aparentemente ligam-se e regulam uma série de outras moléculas. Diversas evidências mostram que as Prxs estão intimamente relacionadas a proliferação, crescimento e diferenciação celulares, além de envelhecimento, câncer, doenças neurodegenerativas e cardiovasculares (Choi et al., 2005; Papadia et al., 2008; Woo et al., 2010; Wei et al., 2011).

As Prxs são bons candidatos a sensores redox, entre outros motivos, por apresentarem elevada reatividade com peróxidos $\left(k \sim 10^{6}-10^{8} \mathrm{M}^{-1} \mathrm{~s}^{-1}\right)$ e serem abundantes. Quando analisados esses dois fatores simultaneamente, é estimado que mais de 99\% do peróxido de hidrogênio no citosol e 90\% na mitocôndria reage com Prxs e é reduzido (Winterbourn e Hampton, 2008; Cox, Winterbourn e Hampton, 2010). No contexto de sinalização redox, deve-se considerar que a reação direta de peróxido de hidrogênio com a maioria das cisteínas protéicas é extremamente lenta $\left(k \sim 10^{1} \mathrm{M}^{-1} \mathrm{~s}^{-}\right.$ $\left.{ }^{1}\right)$, sendo razoável a mediação por alguma peroxidase baseada em cisteína (Winterbourn, 2008; Netto et al., 2016). 
Os mecanismos pelo quais Prxs percebem e ativam as vias de sinalização estão sendo investigados (Fig.3). Após a oxidação de sua CysP, Prxs poderiam seletivamente receber elétrons de proteínas reguladoras (como tirosina fosfatases), através de interações proteína-proteína (Winterbourn e Hampton, 2008). Em apoio a este modelo, Yap1 e CAD1, dois reguladores de transcrição de levedura, são indiretamente ativados por peróxidos, em reações mediadas por Prx (Delaunay et al., 2002; Iwai, Naganuma e Kuge, 2010). Além disso, Prx 1 de mamíferos interage com as quinases c-Abl e JNK, com a fosfatase PTEN e com o regulador c-Myc (Wen e Van Etten, 1997; Kim et al., 2006; Cao et al., 2009).

Outra proposta sobre o envolvimento de Prxs em sinalização redox resultou da observação de que estes peroxidases podem ser inativadas por superoxidação de CysP pela ação de peróxido de hidrogênio (Seo et al., 2009; Peskin et al., 2013) ou por fosforilação de resíduos de Tyr, mediadas pela quinase Src (Woo et al., 2010), provocando um acúmulo local de níveis de peróxido de hidrogênio no interior de um determinado compartimento subcelular. Dessa maneira, seria possível que peróxido de hidrogênio atingisse outros alvos que apresentam menor reatividade a esse oxidante, como tirosina fosfatases. Nesse sentido, é interessante observar que em comparação com enzimas equivalentes de mamíferos, Prxs bacterianas são centenas de vezes mais resistentes à super-oxidação de CysP a sulfinato (CysP-SO $\left.{ }_{2} \mathrm{H}\right)$. Esta facilidade de Prxs eucarióticas para sofrerem inativação por substrato parece representar um ganho evolutivo. De fato, algumas Prxs eucarióticas apresentam motivos protéicos específicos que conferem maior sensibilidade a peróxidos (Wood, Poole e Karplus, 2003). Em apoio a esta proposta, os sulfinatos destas Prxs são especificamente reduzíveis por enzimas chamadas de sulfirredoxinas, em processos dependentes de ATP, indicando que a 
sensibilidade a hiperoxidação deve ter sido selecionada durante a evolução (Biteau, Labarre e Toledano, 2003).

Um terceiro mecanismo pelo qual Prxs poderiam atuar em sinalização celular está relacionado com o fato dessas enzimas poderem oxidar Trx durante seu ciclo catalítico que, por sua vez, poderia ativar (ou inibir) vias de sinalização de maneira específica, através de interações físicas com proteínas reguladoras, como fosfatases e quinases (revisado por Netto e Antunes, 2016).

De fato, diversas vias de transdução de sinal são ativadas por Trx oxidada, mas não por sua forma reduzida (Berndt, Lillig e Holmgren, 2007). Por exemplo, apenas Trx reduzida se liga a Ask-1, inibindo sua atividade quinase. A oxidação de Trx1 leva à dissociação física do complexo e, consequentemente, à ativação de Ask-1 (Saitoh et al., 1998). Outro exemplo é a ativação do NF-kB por Trx1. A ligação da subunidade p50 para a sua sequência alvo no DNA requer a redução de um único resíduo de cisteína por Trx1 (Matthews et al., 1992; Hayashi, Ueno e Okamoto, 1993). No entanto, a oxidação direta de Trx por hidroperóxidos é lenta (Winterbourn, 2008). Dessa maneira, é provável que Prxs possam catalisar esta reação in vivo (Tairum et al., 2012). No mesmo sentido, a sensibilidade de Prx eucariótica à superoxidação (e, consequentemente, a inativação) pode estar relacionada com a transdução de sinais através do aumento dos níveis de Trx reduzida em relação à forma oxidada (Day et al., 2012). 


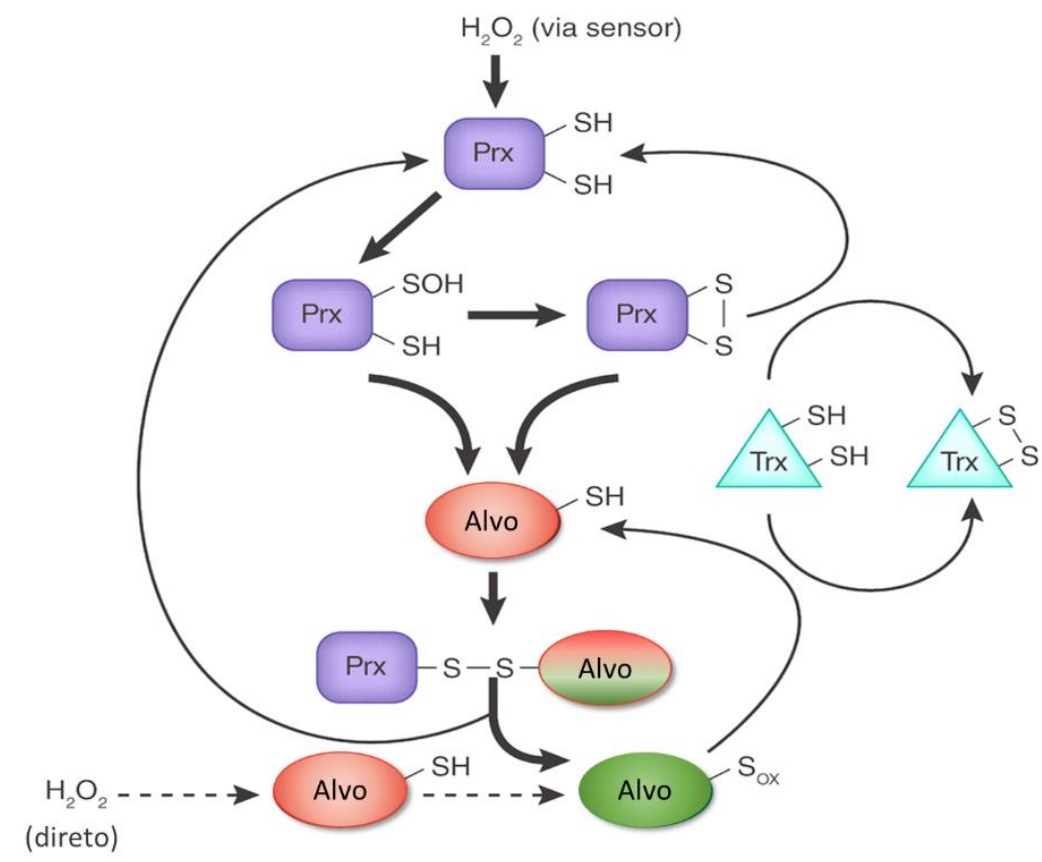

Figura 3. Mecanismos de regulação de proteínas por peróxido de hidrogênio via Prx. O mecanismo de Prx como sensor para a ativação de uma proteína regulatória (alvo) pode envolver a oxidação da Prx para sua forma ácido sulfênico ou dissulfeto, a formação de um dissulfeto misto com a proteína-alvo e por último a oxidação dessa proteína e a redução da Prx. Como alternativa, a oxidação via Prx pode impedir que a Trx seja mantida reduzida e possa reduzir a proteína-alvo. Além disso, o mecanismo de oxidação direta também é conhecido, e pode ser facilitado pela colocalização da fonte de peróxido de hidrogênio com o alvo e/ou através da inativação de proteínas mais reativas (como as Prxs) por peróxido de hidrogênio, como proposto pelo modelo de "floodgate". Modificado de Winterbourn e Hampton, 2015.

Todos os mecanismos descritos acima são suportados por dados relevantes da literatura. Sendo assim, as três propostas são, até o presente momento, igualmente possíveis e não são necessariamente excludentes, porque devem ser consideradas no contexto em que foram descritas.

\subsection{Sinalização redox em células-tronco}

\subsubsection{Células-tronco}

As células-tronco são definidas como células que possuem capacidade de autorrenovação e diferenciação em vários tipos celulares. A capacidade de 
autorrenovação refere-se a um processo que envolve proliferação, acompanhada pela manutenção de multipotência e do potencial de regeneração de tecidos. Por outro lado, a diferenciação indica a habilidade das células-tronco de se especializarem em uma variedade de linhagens celulares e tecidos (He, Nakada e Morrison, 2009) (Fig. 4). Devido a essas propriedades, as células-tronco são capazes de formar um indivíduo inteiro a partir do zigoto, promover todo seu desenvolvimento e reparo de células que são perdidas durante o metabolismo normal e em condições de injúria (Fuchs e Chen, 2013). Assim, elas mantêm a homeostase do tecido ao longo de toda a vida de um organismo multicelular.

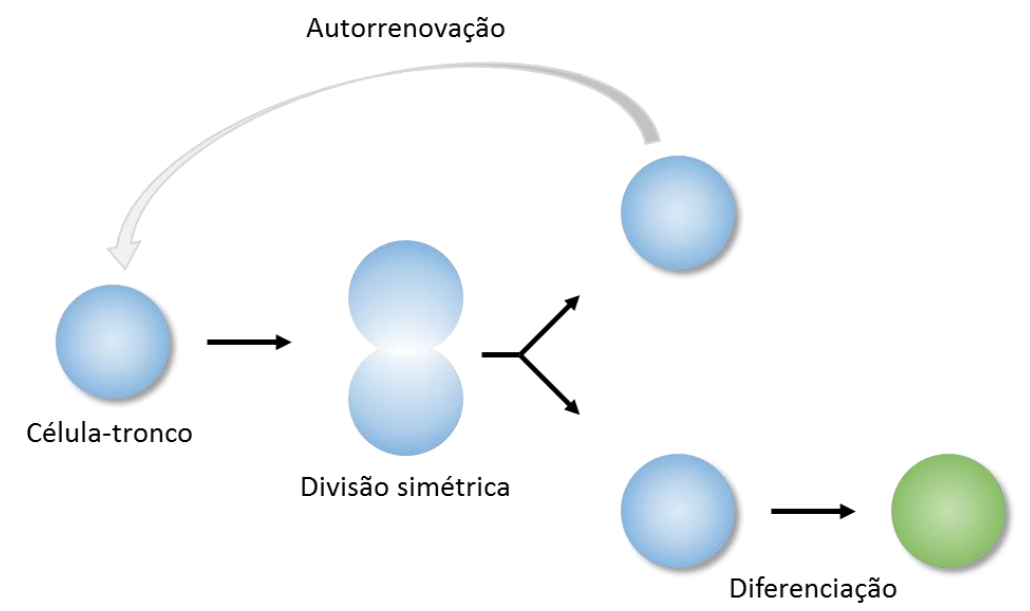

Figura 4. Autorrenovação e diferenciação em células-tronco. As células-tronco mantém seu potencial de autorrenovação através do processo de divisão celular no qual pelo menos uma das células-filha é também uma célula indiferenciada. Já o processo de diferenciação celular pode ocorrer através de alterações metabólicas, transcricionais, epigenéticas, etc, que transformam uma célula-tronco indiferenciada em uma célula diferenciada.

\subsubsection{Diferenciação Celular}

A indução da diferenciação depende de uma série de fatores finamente coordenados, incluindo sinais do local onde essas células se encontram, como disponibilidade de oxigênio, presença de fatores de crescimento, citocinas e outros sinais extracelulares, e também vias de sinalização intracelulares. As modificações 
intracelulares classicamente relacionadas à diferenciação incluem alterações epigenéticas, transcricionais e metabólicas, que em última instância levam a alteração na expressão gênica (Lu et al., 2009; Meissner, 2010).

Apesar da importância dos processos genéticos e epigenéticos na regulação da diferenciação celular, recentemente, diversos processos regulatórios relacionados ao metabolismo de proteínas vêm sendo descritos como essenciais à manutenção e diferenciação de células-tronco. Entre eles, podemos citar a regulação da tradução de proteínas, modificações pós-traducionais em uma variedade de proteínas, degradação de proteínas oxidadas e regulatórias e alterações relacionadas ao metabolismo redox (Buckley et al., 2012; Strikoudis, Guillamot e Aifantis, 2014; Demasi, Simões e Bonatto, 2015 - Anexo I). Esses processos são responsáveis principalmente (i) pelo controle da síntese e degradação de proteínas relacionadas a fases específicas do ciclo celular ou de programas de diferenciação, (ii) pela manutenção da homeostase celular, prevenindo o acúmulo de proteínas danificadas que podem levar a senescência e morte de célulastronco e (iii) pela modulação da atividade de proteínas, por fosforilação e oxidação, por exemplo, durante estados de multipotência e diferenciação. As proteínas-alvo dessas alterações ainda estão sendo caracterizadas, bem como sua importância em cada contexto celular.

\subsubsection{Metabolismo energético na diferenciação celular}

Diferentes estados celulares requerem programas metabólicos específicos para suprir a demanda energética necessária para suas funções especializadas. No caso das células-tronco, o estado de quiescência é caracterizado pela baixa atividade metabólica, baixa necessidade energética e baixa produção de oxidantes. No entanto, a indução à 
diferenciação requer uma alteração para um metabolismo que suporte a alta demanda energética para desenvolver todo o programa de diferenciação.

As células-tronco mesenquimais (MSC) residem em ambiente hipóxicos in vivo e expressam altos níveis de enzimas glicolíticas e baixos níveis de proteínas da fosforilação oxidativa, quando comparados a osteoblastos diferenciados da medula óssea, por exemplo, sugerindo que as MSC são mais glicolíticas que as células diferenciadas (Chen et al., 2008). As células-tronco embrionárias (ESC) em cultura também exibem baixos níveis de fosforilação oxidativa e, nesses casos, a síntese de ATP é desacoplada do consumo de $\mathrm{O}_{2}$ pela cadeia de transporte de elétrons da mitocôndria, e é mais dependente da glicólise (Zhang et al., 2011). Estudos de morfologia e conteúdo de DNA mitocondrial sugerem que essas células possuem menos mitocôndrias - que são mais imaturas e com localização limitada a região perinuclear, comparativamente a células diferenciadas (Chung et al., 2007; Prigione et al., 2010).

Quando as células-tronco se diferenciam, o fluxo glicolítico diminui dramaticamente e a fosforilação oxidativa mitocondrial aumenta (Fig. 5) (Cho et al., 2006; Chung et al., 2007; Wang et al., 2009). Além disso, durante a diferenciação de células-tronco embrionárias de camundongo (mESC), diferentes parâmetros redox são alterados como: a razão de glutationa reduzida para oxidada que diminui, assim como o nível de NADH, aumentando efetivamente o estado oxidativo geral das células (Wang et al., 2009; Yanes et al., 2010). Por outro lado, foi demonstrado que durante o processo de reprogramação celular para indução da pluripotência (de uma célula somática diferenciada para uma iPSC - célula-tronco pluripotente induzida) é visto a alteração de um metabolismo baseado em fosforilação oxidativa para um metabolismo glicolítico (Folmes et al., 2011). 


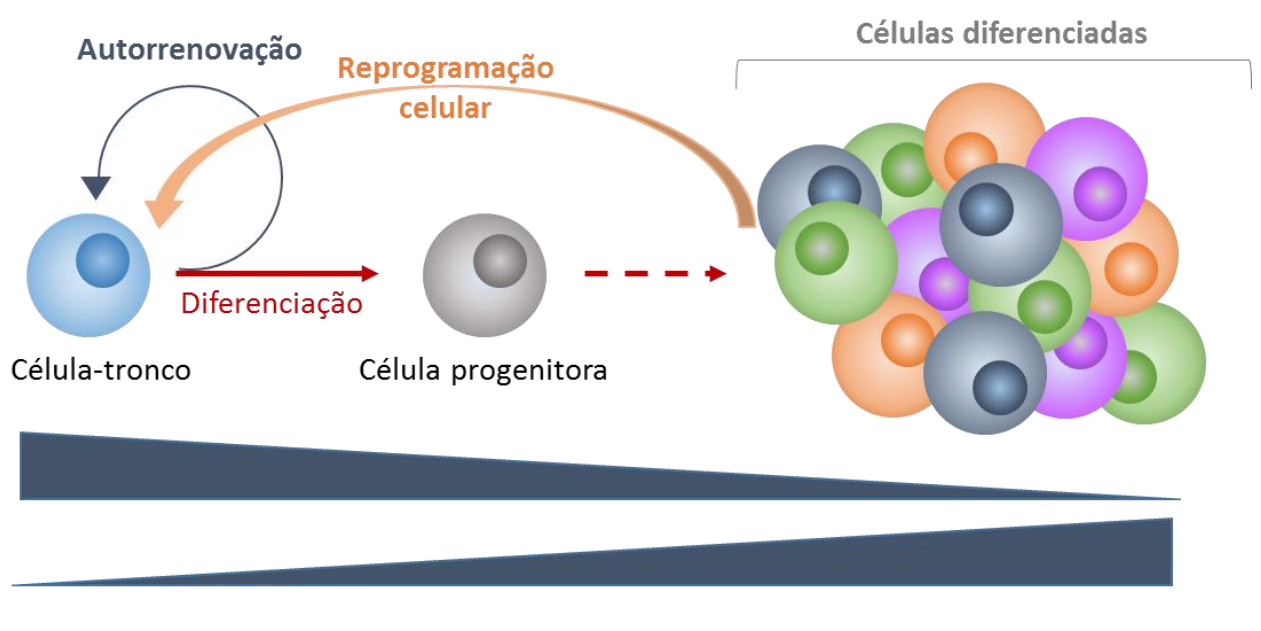

Figura 5. Regulação da função de células-tronco pelo metabolismo. As mitocôndrias são relativamente inativas em células-tronco e, por consequência, a fosforilação oxidativa também, e as células dependem fortemente de um metabolismo glicolítico. O mesmo acontece para células-tronco pluripotentes induzidas. Durante a diferenciação celular, ocorrem alterações metabólicas e a fosforilação oxidativa é predominante ao final deste processo. Modificado de Ito e Suda, 2014.

As MSC cultivadas em condições de normóxia são capazes de utilizar a fosforilação oxidativa e consumir $\mathrm{O}_{2}$ em altas taxas, o que significa que a glicólise pode ser uma adaptação ambiental das MSC ao ambiente hipóxico em que se encontram (Pattappa et al., 2011). Além disso, a taxa de proliferação e capacidade de formação de colônia de MSC aumentam substancialmente em condições de normóxia (Pattappa et al., 2013). Esses dados sugerem que a glicólise induzida por hipóxia limita a proliferação de MSC, prevenindo senescência induzida por estresse oxidativo e preservando o potencial de autorrenovação das células-tronco.

\subsubsection{Controle redox da diferenciação celular}

A diferenciação celular e o desenvolvimento de organismos multicelulares são processos controlados e conduzidos por moléculas e cascatas sinalizadoras específicas, incluindo mecanismos de regulação redox. Uma das primeiras observações sobre o papel do metabolismo redox durante o desenvolvimento e diferenciação data de 1910, 
quando Otto Warburg descreveu eventos oxidativos em ovos de ouriço-do-mar (Warburg, 1910). Já na década de 2000, foi reportado por Smith e colaboradores que o estado redox intracelular parecia ser um modulador necessário para a manutenção do balanço entre autorrenovação e diferenciação em células precursoras do sistema nervoso (Smith et al., 2000). Em geral, baixos níveis de ROS são necessários para manter o estado de quiescência em algumas células-tronco, como HSC (Jang e Sharkis, 2007). O aumento das ROS em células-tronco resulta em uma atividade de autorrenovação prejudicada e aumenta a senescência celular.

Recentemente, evidências tem sugerido que as ROS atuam como segundo mensageiro que modula a autorrenovação e diferenciação de células-tronco através da regulação de intrincadas redes de sinalização, uma vez que muitos reguladores de autorrenovação e diferenciação (incluindo quinases e fatores de transcrição) são suscetíveis a alterações redox (Wang et al., 2013; Ren et al., 2015).

O mecanismo para esse controle das ROS em células-tronco inclui um grande repertório de defesas antioxidantes e a via de PI3K-AKT-mTOR relativamente inativa, todos operando em condições de hipóxia (Ito e Suda, 2014). Estudos mostram que ESC e iPSC humanas possuem mecanismos de defesa antioxidantes mais eficientes do que células em diferenciação (Saretzki et al., 2008; Armstrong et al., 2010), que garantem a produção controlada de ROS. Várias observações recentes confirmaram que baixos níveis de ROS mantém o estado indiferenciado ou de quiescência de células-tronco, enquanto que altos níveis promovem a diferenciação de diversos tipos celulares (Ren et al., 2015).

Ainda sobre a diferenciação celular, diversos trabalhos mostraram que as ROS têm papel fundamental em vários modelos celulares. Por exemplo, durante o processo 
de diferenciação de MSCs em adipócitos, um efetor da via de sinalização PI3K/Akt, mTORC1, é responsável pela sinalização que leva ao aumento no metabolismo mitocondrial e geração de ROS (Tormos et al., 2011), bem como acontece na ativação de B-catenina durante a diferenciação epidermal (Hamanaka et al., 2013), mostrando que a geração dessas ROS é essencial para esses processos. Outros trabalhos mostram que o aumento de níveis endógenos de ROS, pela atividade do complexo NOX, favorecem a neurogênese (Wang et al., 2007; Yanes et al., 2010; Le Belle et al., 2011) e a diferenciação de células da linhagem de cardiomiócitos (Ateghang et al., 2006; Buggisch et al., 2007; Sharifpanah et al., 2008). Além disso, observa-se a diminuição na expressão de vários antioxidantes durante a diferenciação celular, como SOD2 e outras (Chaudhari, Ye e Jang, 2012).

Tanto a diferenciação adipogênica quanto a osteogênica levam ao aumento da fosforilação oxidativa e biogênese mitocondrial (Chen et al., 2008; Tormos et al., 2011). As ROS geradas pelo complexo III da cadeia de transporte de elétrons são necessárias para iniciar a adipogênese, sugerindo que a fosforilação oxidativa e as ROS não são simplesmente uma consequência do processo, mas um fator causal na promoção da adipogênese (Tormos et al., 2011). Em contraste à adipogênese e osteogênese, MSC induzidas a condrogênese tem consumo de $\mathrm{O}_{2}$ e fosforilação oxidativa significativamente reduzidos, indicando alteração a favor do aumento da glicólise (Pattappa et al., 2011). Esses estudos demonstram que a manipulação cuidadosa do metabolismo oxidativo pode direcionar a diferenciação de MSC em adipócitos, osteoblastos ou condrócitos.

Portanto, esses mecanismos de controle de produção e remoção de ROS em células-tronco são essenciais tanto para manutenção da integridade dessas células, 
evitando danos ao genoma e a macromoléculas, como para a sinalização que promove a proliferação ou diferenciação celular.

\subsection{Diferenciação osteogênica}

O osso é um tecido mesenquimal mineralizado, que possui pelo menos duas funções biológicas essenciais. Como um órgão endócrino que regula a homeostase mineral e metabolismo energético, o osso responde e sinaliza a diversos outros sistemas vitais (por exemplo, a glândula paratireoide, rins, sistema vascular, tecido adiposo, hipotálamo, etc). Como o principal tecido conectivo estrutural, os ossos suportam a locomoção e protegem órgãos essenciais.

\subsubsection{Formação e reabsorção óssea}

A homeostase do esqueleto de mamíferos, depois da embriogênese, é mantida através da atividade de osteoblastos, responsáveis pela formação de ossos, e osteoclastos, que são responsáveis pela reabsorção óssea. Os osteoblastos originam-se de progenitores mesenquimais via preosteoblastos e podem se tornar osteócitos, cercados pela matriz óssea. Os osteoclastos são células reabsortivas derivadas de células-tronco de linhagem hematopoiética.

\subsubsection{Etapas da diferenciação de osteoblastos}

Diversas alterações metabólicas e funcionais marcam as etapas de diferenciação e maturação das células até osteoblastos. O processo todo pode ser dividido em vários 
estágios, incluindo proliferação, deposição de matriz extracelular, maturação e mineralização da matriz (Fig. 6) (Stein e Lian, 1993).

Para investigar a diferenciação de osteoblastos, os níveis de expressão de marcadores de diferenciação são utilizados, incluindo fosfatase alcalina ( $A L P$ - alkaline phosphatase), colágeno tipo I (Col1- type I collagen), osteopontina (OPN-osteopontin) e osteocalcina (OC - osteocalcin). Enquanto ALP é usado como marcador de etapas iniciais da diferenciação osteogênica, OC é considerado marcador de etapas tardias.

(A)

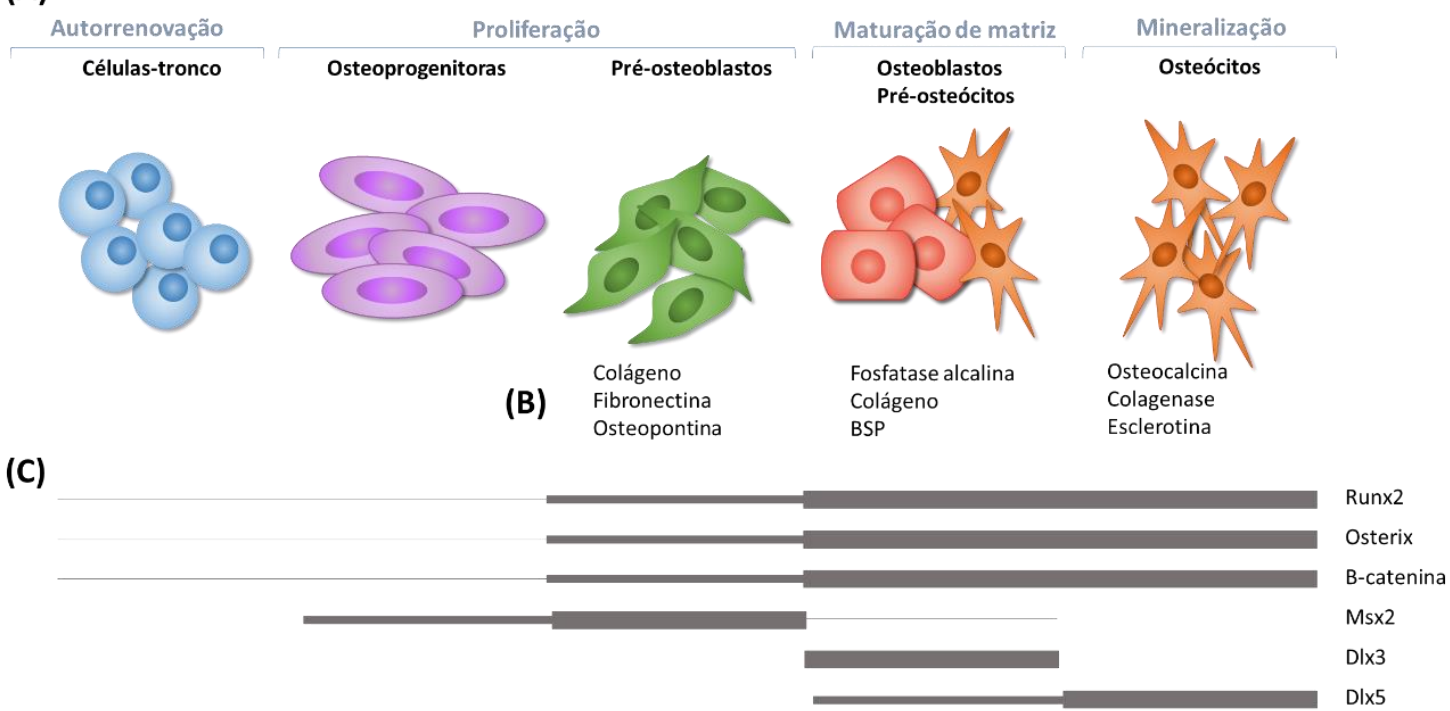

Figura 6. Etapas da diferenciação osteogênica. A formação de ossos pela linhagem de células dos osteoblastos e as principais atividades funcionais dessas células dependem de diversas etapas na indução da osteogênese. (A) Tipos celulares e principal atividade das células. (B) Principais proteínas expressas em cada etapa da diferenciação osteogênica. (C) Principais fatores de transcrição de cada etapa da diferenciação. Adaptado e modificado de Lian et al., 2012.

\subsubsection{Sinalização celular na diferenciação osteogênica}

Vários fatores são conhecidos por serem potentes indutores da formação de ossos a partir de células osteoprogenitoras, tanto in vivo como in vitro. Neste trabalho, optamos por induzir a diferenciação com BMP2, por ser uma estratégia que nos oferece um modelo de diferenciação mais específico e por termos mais informações sobre os 
marcadores que devemos utilizar para os experimentos. Dessa forma, é importante esclarecermos as diferenças entre as duas vias de indução à osteogênese mais relevantes in vivo e melhor caracterizadas in vitro, a via de TGF- $\beta$ e a via de BMP2, porque são vias que compartilham alguns mediadores, além de possuírem seus mediadores específicos (Fig. 7).

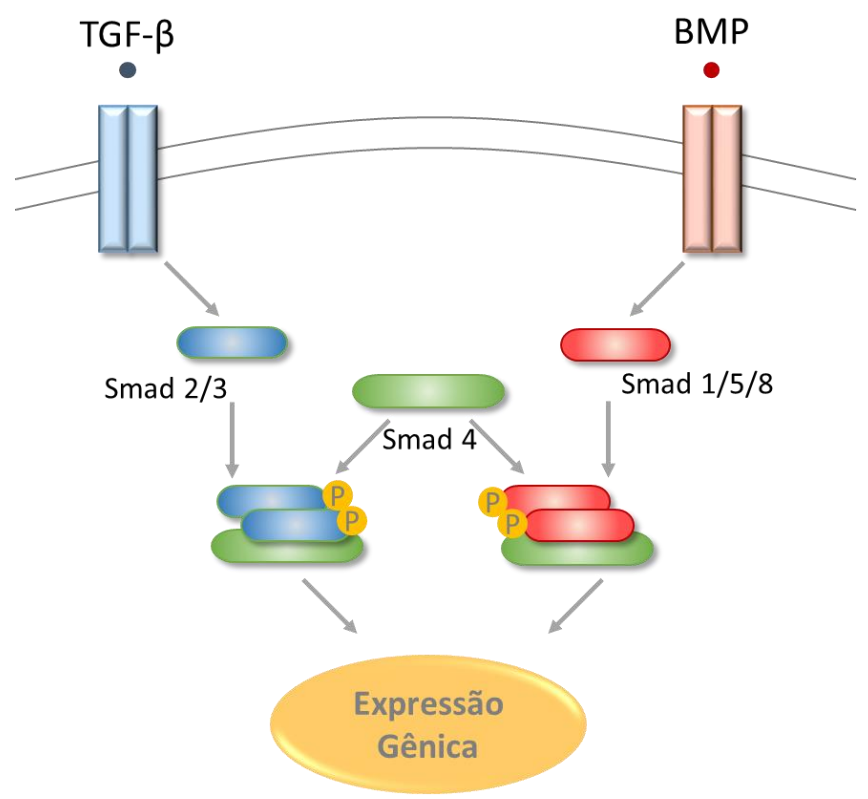

Figura 7. Principais vias relacionadas a diferenciação osteogênica.

As vias de TGF- $\beta$ e de BMP influenciam a diferenciação osteogênica por diferentes mediadores intracelulares. Os mediadores da via ativada por BMP são principalmente as proteínas Smad 1, 5 e 8 e os mediadores da via ativada por TGF- $\beta$ são principalmente as proteínas Smad 2 e 3.

A sinalização autócrina e parácrina por TGF- $\beta$ é importante para a manutenção e expansão de células-tronco, além de promover a diferenciação inicial e comprometimento dessas células para linhagem osteoblástica, através das vias de MAPKs e Smad 2/3 e da cooperação entre as vias de TGF- $\beta$ e PTH, Wnt, BMP, bem como a sinalização via FGF (Derynck e Akhurst, 2007; Chen, Deng e Li, 2012). Algumas isoformas de TGF- $\beta$ (Transforming Growth Factor $\beta$ ) e seus receptores tipo I (TGF $\beta$ RI ou 
ALK5) ou tipo II (TGFßRII ou Tgfbr2) tem papel importante na ossificação endocondral e intramembranosa (Baffi, Moran e Serra, 2006; Matsunobu et al., 2009).

A transdução de sinal é iniciada com a ligação de TGF- $\beta$ aos receptores tipo I e tipo II, que fosforilam e ativam as proteínas Smad 2 e 3, que por sua vez formam um complexo com Smad 4. Este complexo é translocado para o núcleo, liga-se a fatores de transcrição, co-ativadores e co-repressores, regulando a expressão de genes alvos. Além desse mecanismo, a via de TGF- $\beta$ é conhecida por regular vias não dependentes de Smad, incluindo ERK, JNK e PI3K-Akt.

As proteínas da família das BMPs exercem diversos papéis na fisiologia dos organismos, desde a formação de ossos e cartilagens até o desenvolvimento de crista neural em fenótipos neuronais (Chen, Zhao e Mundy, 2004). As BMPs -2, -6, -7 e -9 induzem a diferenciação de células precursoras em osteoblastos e produzem um conjunto distinto de marcadores moleculares durante a diferenciação. BMP-2 e BMP-6, em particular, promovem fortemente a osteogênese em células-tronco (Friedman, Long e Hankenson, 2006; Luu et al., 2007).

As BMPs exercem seus efeitos biológicos diversos através da ativação de dois tipos de receptores transmembrana: BMPR-I (BMP receptor type I) e BMPR-II (BMP receptor type II), que possuem atividade serina/treonina quinase (Heldin, Miyazono e Ten Dijke, 1997). A ligação das BMPs ao receptor heteromérico ativa as moléculas de sinalização intracelular Smad 1, 5 e 8, através da fosforilação de suas serinas (Herpin e Cunningham, 2007). As proteínas Smad ativadas formam um heterodímero com Smad4 e são transportadas para o núcleo, onde eles regulam a transcrição de genes alvo (Fig 7). A BMP2 estimula a transcrição de Runx2, um regulador master da diferenciação osteogênica, e as proteínas Smad ativadas por BMP2 colaboram com Runx2 para induzir 
outros genes importantes para a diferenciação osteogênica, como Osterix (Osx/Sp7) (Derynck e Zhang, 2003; Lian et al., 2006).

\subsubsection{A importância da sinalização redox na diferenciação osteogênica}

A literatura traz uma grande quantidade de trabalhos que mostram 0 envolvimento de ROS em vias de sinalização associadas à diferenciação de MSC. A ligação de fatores de crescimento a seus receptores promove a ativação de produção de ROS pelas mitocôndrias ou pela NOX, que podem então reagir com outros substratos, como quinases e fosfatase, regulando sua atividade.

Experimentos in vitro servem como ferramentas para estudar o controle de vias de diferenciação celular. Alguns estudos mostram o envolvimento de ROS na osteogênese, entretanto, não existem estudos sistemáticos que demonstrem os mecanismos pelos quais essas ROS atuam, bem como a regulação de enzimas como Prx e Trx, diretamente envolvidas no metabolismo redox.

A investigação de modificações redox no processo de diferenciação osteogênica pode trazer novos elementos para otimizar os protocolos de diferenciação em célulastronco, para usos em modelos in vitro, in vivo ou em experimentos pré-clínicos associados a testes de terapias celulares. 


\section{Objetivos}

O objetivo geral deste projeto é investigar alterações redox e possíveis efeitos de peróxido de hidrogênio, associado a modulação por antioxidantes, como reguladores do processo de diferenciação osteogênica.

Nossa hipótese é que a indução in vitro à diferenciação osteogênica pode elevar a produção endógena de peróxido de hidrogênio, com papel importante na sinalização que promove a diferenciação.

\section{Objetivos específicos:}

- Analisar parâmetros redox durante a indução de diferenciação osteogênica de células murinas da linhagem MC3T3-E1 com BMP2:

- Validar os dados da literatura relacionados a eficiência de diferenciação com tratamentos que estimulam ou inibem a produção de peróxido de hidrogênio, utilizando marcadores de diferenciação osteogênica;

- Buscar a (s) molécula (s) que participam do processo e seus possíveis alvos.

- Analisar a regulação dos sistemas antioxidantes durante a diferenciação osteogênica:

- Identificar alterações de expressão gênica e estado de oxidação de componentes de sistemas antioxidantes, principalmente Prx. 


\section{Material e Métodos}

\subsection{Cultura celular}

As células cultivadas para os experimentos desta dissertação foram a linhagem comercial MC3T3-E1, subclone 14 (ATCC - CRL-2593), cultivadas em meio de crescimento contendo $\alpha$-MEM, suplementado com $10 \%$ de soro fetal bovino e $1 \%$ de antibiótico PenStrep (todos soluções da Gibco - Life Technologies), em estufa a $37^{\circ} \mathrm{C}$, com $5 \% \mathrm{CO}_{2}$. As células foram utilizadas entre as passagens 6 e 12 .

\subsection{Indução da diferenciação osteogênica}

A diferenciação celular foi induzida pela substituição do meio de crescimento basal por meio de crescimento suplementado com ácido ascórbico, $\beta$-glicerofosfato (ambos da empresa Sigma Aldrich) e hrBMP2 (Life Technologies), quando necessário, nas concentrações citadas em cada experimento. As células foram mantidas nesse meio, que era trocado a cada três dias, até o momento da quantificação de parâmetros de diferenciação.

\subsection{Marcação de matriz extracelular mineralizada por Alizarin Red}

As células MC3T3-E1 submetidas à diferenciação por períodos de tempo maiores que dez dias foram submetidas a coloração por Alizarin Red, que marca a deposição de matriz extracelular mineralizada em fases mais adiantas da diferenciação. Após os dias de cultivo em meio osteogênico indicados em cada experimento, as células foram fixadas na placa com $500 \mu \mathrm{L}$ de solução de etanol $70 \%$ e coradas com $500 \mu \mathrm{L}$ de solução de Alizarin Red (0,2\% em PBS), por 30min, a temperatura ambiente. A solução corante foi descartada e os poços foram lavados por três vezes com $500 \mu \mathrm{L}$ de PBS. As placas 
foram deixadas para secar overnight e foram posteriormente fotografadas. Nos casos indicados, foi feita a quantificação da marcação por espectrofotometria, após incubação das placas coradas com $500 \mu \mathrm{L}$ de solução de $20 \%$ metanol e $10 \%$ ácido acético por 15 min. O sobrenadante foi coletado e a quantificação foi feita a 450nm, em placas de 96 poços, em equipamento Epoch Microplate Spectrophotometer (BioTek).

\subsection{Western Blot}

A preparação do extrato celular das células MC3T3-E1 consistiu no rompimento físico das células, com a utilização de Cell Scraper (Sigma-Aldrich), na presença de tampão RIPA com inibidor de protease e inibidor de fosfatase. Amostras de extrato celular foram separadas previamente por eletroforese em gel de poliacrilamida (SDSPAGE). As proteínas do gel foram transferidas para uma membrana de nitrocelulose de $0,22 \mu \mathrm{M}$ (Hybond-ECL da GE Healthcare) pelo sistema de transferência semi-seca Lightning Blotter (PerkinElmer), por 30 min, com corrente elétrica constante em 600mA. Em seguida, a membrana foi lavada em tampão TBS (Trizma $\mathrm{HCl}, \mathrm{NaCl} ; \mathrm{pH} 7,6$ ) com 0,1\% de Tween-20. O bloqueio da membrana foi feito com Blotting-Grade Blocker (Bio-Rad) (5\%) em tampão TBS + Tween por 1h. A membrana foi lavada com TBS e incubada com o anticorpo primário (diluído de acordo com o protocolo de cada fabricante) overnight a $4^{\circ} \mathrm{C}$. A membrana foi lavada novamente com TBS 3 vezes por 10 min e incubada com o anticorpo secundário (anti-IgG de coelho ou de camundongo) conjugados com HRP (Horseradish peroxidase) por 1 h. Para a revelação, a membrana foi incubada com solução do kit ECL Prime (GE) (contendo peróxido de hidrogênio), que gera quimiluminescência e então as membranas marcadas foram expostas em filme 
radiográfico Hyperfilm (Amersham) e o filme foi revelado. As imagens foram feitas pela digitalização dos filmes.

\subsubsection{Western Blot redox}

Para determinar o estado de oxidação intracelular de oxidoredutases, padronizamos a extração de proteínas, tentando preservar esse estado de oxidação. As células foram raspadas da placa na presença de TCA $10 \%$ e o extrato celular foi mantido no gelo por $30 \mathrm{~min}$. Após centrifugação por 10 minutos, $13000 \mathrm{rpm}$ a $4^{\circ} \mathrm{C}$, as células foram ressuspendidas em tampão de amostra contendo $100 \mathrm{mM}$ de NEM, incubadas por $1 \mathrm{~h}$ a $37{ }^{\circ} \mathrm{C}$ e posteriormente fervidas por $5 \mathrm{~min}$ a $96 \circ \mathrm{C}$ e aplicadas em gel SDS-PAGE.

\subsection{Preparo dos reagentes de tratamento}

Os principais reagentes utilizados no tratamento das células neste trabalho foram Peróxido de Hidrogênio, N-acetilcisteína (NAC) e PEG-catalase. A solução de trabalho de peróxido de hidrogênio foi feita sempre fresca, a partir de solução estoque 8,9M a uma concentração de $5 \mathrm{mM}$, em água MilliQ. A solução de trabalho NAC (Sigma) foi feita em uma concentração de $250 \mathrm{mM}$, em tampão fosfato de sódio ( $200 \mathrm{mM}$, pH 8 ) e o pH da solução foi ajustado para 7 com solução de NaOH 1M. A PEG-catalase (Sigma) foi solubilizada em tampão fosfato de sódio $(10 \mathrm{mM} \mathrm{pH} \mathrm{7,4)} \mathrm{em} \mathrm{uma} \mathrm{solução} \mathrm{de} \mathrm{trabalho}$ a $200 \mathrm{U} / \mu \mathrm{L}$.

\subsection{Proliferação celular}

O ensaio de proliferação celular por XTT foi utilizado para medir a sobrevivência e proliferação celular após o tratamento com NAC, peróxido de hidrogênio e PEGcatalase. O tratamento das células e a coleta do primeiro ponto foram feitos no primeiro 
dia após o plaqueamento. As células foram tratadas com as concentrações indicadas em cada experimento de peróxido de hidrogênio, NAC e PEG-catalase em meio de cultura $\alpha$-MEM (Gibco), por quarenta e cinco minutos. A quantificação das células foi feita de maneira indireta utilizando o kit com reagente XTT (Cell Proliferation Kit II - Roche). A cada dia, foi retirado o meio de cultura de uma das placas, e as células foram incubadas com a solução de XTT + PMS, de acordo com o fabricante, por $4 \mathrm{~h}$, a $37^{\circ} \mathrm{C}$. A curva de proliferação foi acompanhada por quatro dias. A quantificação foi feita por absorbância a 450nm, o controle de absorbância inespecífica foi feito a $630 \mathrm{~nm}$ e esse valor foi subtraído da medida feita a 450nm, resultando no valor de absorbância corrigido.

\subsection{Ensaio de Unidades Formadoras de Colônia}

Este ensaio consiste no tratamento de um número determinado de células e posterior avaliação das células que sobreviveram ao tratamento e proliferaram a ponto de forma colônias de células. Para este projeto, foram plaqueadas 40 células em placa de 6 poços, de modo que as células se distribuíram uniformemente pela placa e fosse possível a contagem de colônias isoladas. As células foram plaqueadas e posteriormente tratadas com os compostos e concentrações indicadas por 45minutos. Posteriormente, o meio foi trocado por meio de crescimento fresco e as células foram mantidas por quatros dias em condições de crescimento. As células foram então fixadas e coradas com tampão PBS contendo $1 \%$ formaldeído $1 \%$ metanol e $0,05 \%$ violeta cristal (Crystal Violet - Sigma). Após cinco a seis ciclos de lavagem, as placas foram levadas a estereomicroscopio e as colônias com 50 células ou mais foram contabilizadas. 


\subsection{Dosagem de peróxido de hidrogênio com Amplex Red}

As células foram contadas e plaqueadas na proporção $1 \times 10^{5}$ células $/ \mathrm{cm}^{2}$, em placa de 24 poços $\left(1,9 \mathrm{~cm}^{2}\right)$, em triplicata, até atingirem confluência aproximada de $70 \%$.

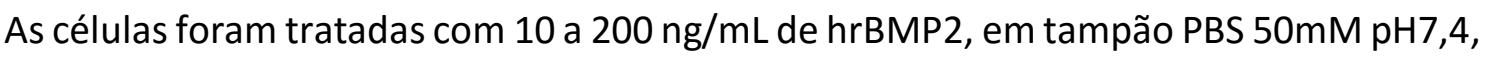
pelo tempo indicado e posteriormente lisadas em 200ul do mesmo tampão. As quantificações foram feitas pela incubação alíquotas de $50 \mu \mathrm{l}$ de extrato celular com 50

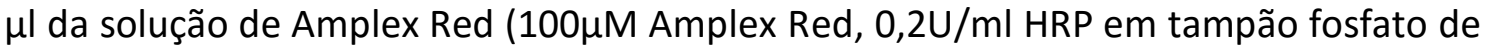
sódio $50 \mathrm{mM} \mathrm{pH} \mathrm{7,4),} \mathrm{em} \mathrm{placa} \mathrm{opaca} \mathrm{de} 96$ poços, incubadas por 30min na ausência de luz. A quantificação foi feita por fluorescência, com excitação em 560nm e emissão em 590nm e as medidas foram dadas em unidades arbitrárias de fluorescência. Os controles do experimento foram o meio de cultura com peróxido e sem células e as células tratadas com meio de cultura sem peróxido.

\section{9. $\quad$ PCR quantitativa em tempo real}

Extração de RNA: O RNA total foi extraído da cultura de células pelo método de Trizol, de acordo com as recomendações The MIQE Guidelines: Minimum Information for Publication of Quantitative Real-Time PCR Experiments (Bustin et al., 2009). A integridade do RNA foi analisada por gel de eletroforese em agarose e quantificação foi feita em Nanodrop 1000.

Síntese de cDNA: Dois microgramas de RNA extraídos da cultura de células foram convertidos em cDNA usando Superscript II (Invitrogen), de acordo com o manual do fabricante. As reações da PRC quantitativa em tempo real (qPCR) foram feitas em duplicata, com volume final de 25uL, com 20ng cDNA, 1x SYBR Green Master Mix (Applied Biosystems) e 100 - 200nM de cada primer (de acordo com padronização de 
cada um dos primers). A fluorescência foi detectada usando ABI Prism 7500 Sequence Detection System (Applied Biosystems), utilizando protocolo de temperatura padrão. Os primers (Tabela I) foram desenhados pelo software IDT (https://www.idtdna.com/site) e sua eficiência de amplificação foi determinado através de curva de diluição seriada de cDNA. A expressão dos genes alvos foi feita relativamente ao gene endógeno $\beta$-actina e o método de análise foi feito de acordo com Livak (2001), pela fórmula de $2^{-\Delta \Delta C t}$.

Tabela I. Tabela de primers de genes usados em qPCR

\begin{tabular}{lll}
\hline Gene & Primer Forward $\left(\mathbf{5}^{\prime} \rightarrow \mathbf{3}^{\prime}\right)$ & Primer Reverse $\left(\mathbf{5}^{\prime} \rightarrow \mathbf{3}^{\prime}\right)$ \\
\hline NOX4 & GAAGGGGTTAAACACCTCTGC & ATGCTCTGCTTAAACACAATCCT \\
PRDX1 & AGGAGGATTGGGACCCATGA & AAGGCCCCTGAAAGAGATACC \\
$\boldsymbol{P R D X 2}$ & CTTTTGTTTGCCCCACGGAG & GGTATTGATCCACGCCAGGT \\
\hline
\end{tabular}




\section{Resultados}

\subsection{Obtenção e cultivo de células}

A linhagem de células escolhida para esse trabalho foi a MC3T3-E1 - subclone 14 (ATCC CRL-2594). A linhagem foi estabelecida a partir da calvaria de camundongos recém-nascidos e as células são classificadas como pré-osteoblastos (Quarles et al., 1992). São células aderentes, de formato fibroblastóide e são um modelo amplamente usado na literatura para estudos de diferenciação osteogênica. A linhagem MC3T3-E1 subclone 14 exibe altos níveis de diferenciação e mineralização após indução por meio contendo ácido ascórbico. (Wang et al., 1999). Utilizamos as células em passagens baixas, uma vez que é descrito na literatura que as células MC3T3-E1 podem ter seu potencial de proliferação e diferenciação diminuídos em função de longos tempos de cultivo e números de "passagens", apresentando sinais de senescência (Chung et al., 1999; Yan, X. Z. et al., 2014).

A linhagem de células utilizada neste trabalho foi gentilmente cedida pelo Prof Dr Paulo Tambasco de Oliveira, da Faculdade de Odontologia de Ribeirão Preto (FORPUSP). Com o auxílio da Prof ${ }^{a}$ Dr $^{a}$ Luciane Capelo (Unifesp), padronizamos as condições de cultivo no laboratório da Prof ${ }^{\mathrm{a}}$ Dr$^{\mathrm{a}}$ Maria Rita Passos Bueno (IB-USP). O cultivo foi realizado em meio $\alpha$-MEM, $10 \%$ de soro feral bovino, $1 \%$ de antibiótico PenicilinaStreptomicina (denominado aqui como meio de crescimento), em estufa a $37^{\circ} \mathrm{C}$, com $5 \% \mathrm{CO}_{2}$. 


\subsection{Diferenciação osteogênica}

As células MC3T3-E1 são pré-osteoblastos, e sua diferenciação para osteoblastos é possível através da suplementação do meio de crescimento com ácido ascórbico e $\beta$ glicerofosfato. Esses dois compostos têm como função, respectivamente, atuar como cofator da enzima colagenase, responsável pela síntese de colágeno, e como fonte de fosfato, necessários para produção de matriz extracelular calcificada (Torii, Hitomi e Tsukagoshi, 1996; Wang et al., 1999; Langenbach e Handschel, 2013). Além disso, dexametasona, ácido ascórbico e $\beta$-glicerofosfato têm sido utilizados em muitos experimentos in vitro para induzir a diferenciação osteogênica de células progenitoras (Pittenger et al., 1999; Jaiswal et al., 2000; Mikami et al., 2007).

Para verificar o potencial de diferenciação da linhagem MC3T3-E1, o primeiro teste realizado teve por objetivo mostrar que as células diferenciam quando induzidas com ácido ascórbico e $\beta$-glicerofosfato, como pode ser visto pela marcação de matriz extracelular calcificada, ao longo do tempo (Fig. 8).

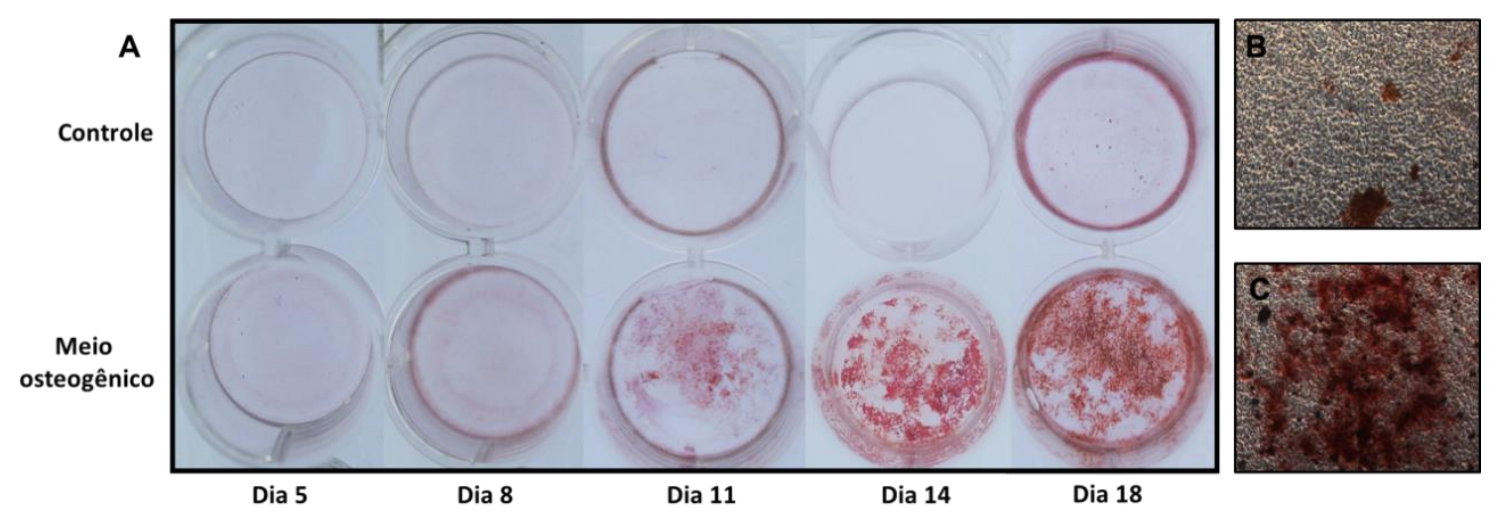

Figura 8. Marcação com Alizarin Red durante a diferenciação oestegênica de MC3T3-E1. (A) As células foram cultivadas em meio osteogênico e meio de crescimento (controle) e a diferenciação foi acompanhada por até dezoito dias, com marcações com Alizarin Red. (B) Detalhe da placa com células em meio basal - indiferenciadas -, e das células em meio osteogênico - diferenciadas (C), com aumento de $40 x$. 
Apesar de o ácido ascórbico ser componente indispensável para a diferenciação, sabe-se que esta molécula pode atuar em vias envolvidas com metabolismo oxidativo, o que poderia trazer uma variável indesejada ao desenvolvimento do projeto.

Para estabelecer a melhor condição de diferenciação, testamos duas concentrações de ácido ascórbico no meio de crescimento com $\beta$-glicerofosfato. 0 resultado do teste mostra que a diferenciação osteogênica pode acontecer perfeitamente em uma concentração intermediária de ácido ascórbico. As células se diferenciaram em meio com 50ug/ml ácido ascórbico tão intensamente quanto em meio com 100ug/ml de ácido ascórbico (Fig. 9). O meio de crescimento suplementado com $50 \mathrm{ug} / \mathrm{ml}$ de ácido ascórbico e $10 \mathrm{mM}$ de $\beta$-glicerofosfato será denominado aqui como meio osteogênico.

(A)

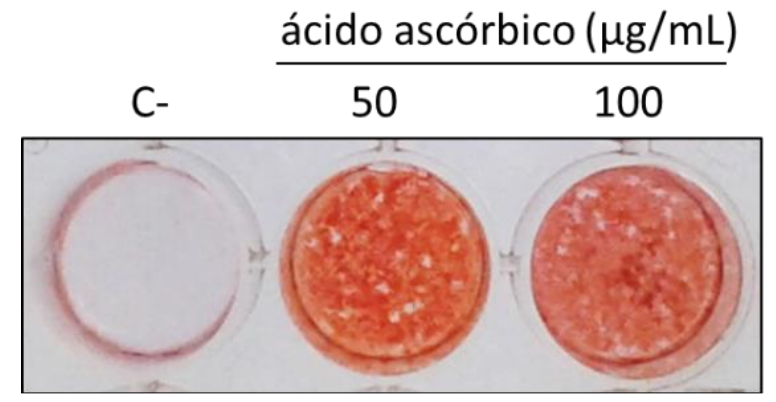

0,9

0,8

(B)

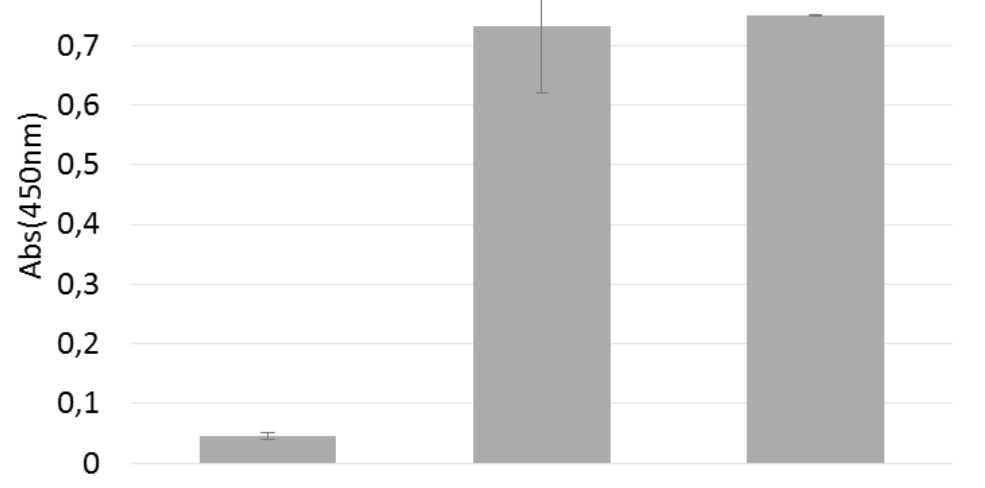

Figura 9. Diferenciação osteogênica com diferentes concentrações de ácido ascórbico. As células foram tratadas apenas com meio de crescimento (C-) ou com o meio de crescimento suplementado com 10mM $\beta$-glicerofosfato e $50 \mathrm{ug} / \mathrm{ml}$ ou $100 \mathrm{ug} / \mathrm{ml}$ ácido ascórbico por 12 dias e posteriormente coradas com Alizarin Red. (A) Imagem representativa e (B) quantificação da coloração por absorbância (450nm) de n=4. 
Apesar do processo de diferenciação osteogênica poder ser desencadeado e suportado apenas pela adição de ácido ascórbico e $\beta$-glicerofosfato no meio de crescimento, ele pode ser otimizado pela adição da proteína BMP2 ao meio osteogênico (Torii, Hitomi e Tsukagoshi, 1996; Luppen et al., 2003). A utilização de BMP2 torna o processo de diferenciação mais específico, se comparado à diferenciação promovida apenas pela adição de ácido ascórbico e $\beta$-glicerofosfato ao meio, porque direciona a sinalização preferencialmente pela via de BMP, em detrimento de outras vias relacionadas a diferenciação osteogênica (ver fig. 7). Essa estratégia é interessante porque temos um modelo mais homogêneo de diferenciação, no qual a participação de outras vias de sinalização, como a de TGF- $\beta$, é diminuída, e assim podemos ser mais assertivos na análise dos marcadores específicos para essa via de diferenciação, como a fosforilação do complexo Smad1/5/8.

Os artigos da literatura utilizam concentrações na faixa de 10 a $300 \mathrm{ng} / \mathrm{mL}$ de BMP2 para induzir a diferenciação osteogênica (Chung et al., 1999; Luppen et al., 2003; Ogasawara et al., 2004; Luppen et al., 2008; Kanzaki et al., 2011). Utilizamos a proteína recombinante humana BMP2 - hrBMP2 (Life Technologies) e testamos condições de diferenciação com a utilização de 10 a 200ng/mL de hrBMP2 no meio de diferenciação.

Os resultados desses estímulos foram analisados em diferentes níveis, desde a ativação da via de sinalização das Smads até a deposição de matriz extracelular calcificada, nas etapas mais tardias de diferenciação osteogênica. Para testar se o tratamento com a hrBMP2 é capaz de ativar preferencialmente a via de BMP2, em detrimento da via de TGF- $\beta$, o primeiro experimento realizado foi a indução da diferenciação com hrBMP2 e a análise da fosforilação das proteínas Smad 1/5/8 e da Smad 2, que indicam a ativação da via de BMP e de TGF- $\beta$, respectivamente. $O$ 
tratamento com hrBMP2 promoveu aumento da fosforilação das proteínas Smad 1/5/8, mas não de Smad 2 (Fig. 10). Esse resultado indica que a via preferencialmente ativada por este protocolo de diferenciação é a via de BMP, como esperado.
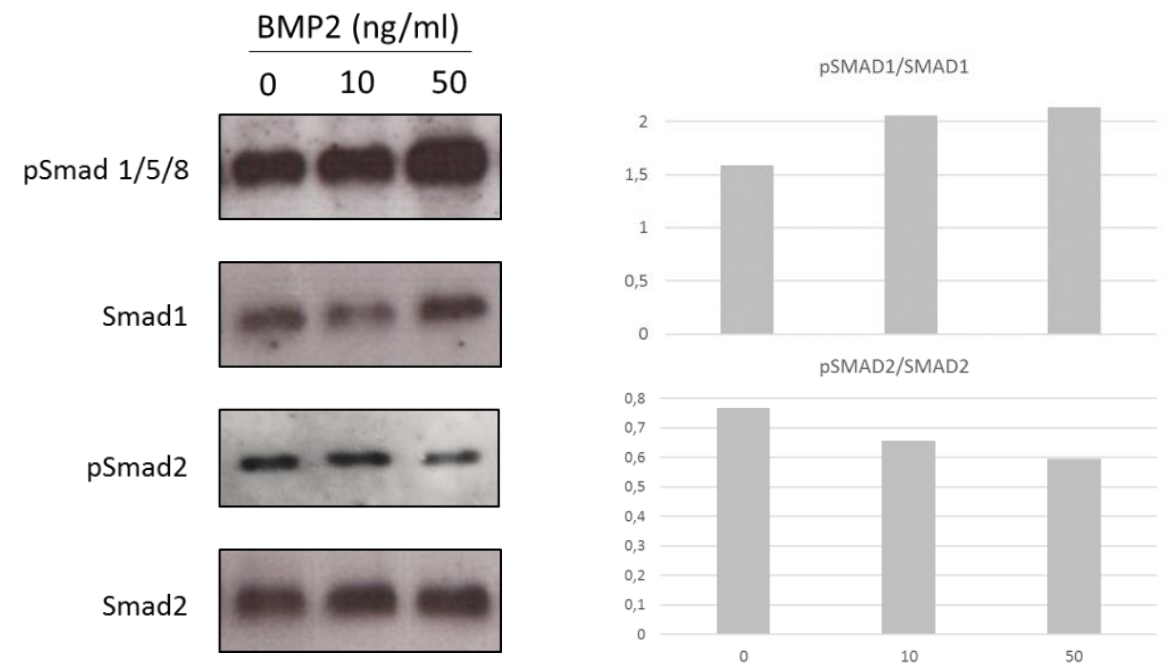

Figura 10. Ativação da via de BMP após o tratamento com BMP2.

As células MC3T3-E1 foram tratadas com as concentrações indicadas de BMP2 em meio osteogênico, por 1 hora. Após o tratamento, as células foram submetidas ao protocolo de Western Blot, conforme descrito em Materiais e Métodos. A figura mostra o filme revelado (esquerda) e a quantificação relativa de bandas, razão entre a banda das formas fosforiladas pelas não-fosforiladas (direita). pSmad 1/5/8 - forma fosforilada do complexo Smad 1/5/8; pSmad2 - forma fosforilada da proteína Smad2.

A marcação de fosforilação nas células que não foram tratadas com BMP2 (controle negativo) pode ser devida a uma atividade da via intrínseca ao modelo celular, uma vez que as células utilizadas aqui são pré-osteoblastos, ou seja, uma linhagem já comprometida com a diferenciação osteogênica e, portanto, com as vias relacionadas a essa diferenciação.

Para seguir com a demonstração do modelo, avaliamos a resposta celular ao tratamento com BMP2 ao nível de alteração na expressão gênica. Para a caracterização da diferenciação osteogênica, escolhemos osteocalcina, um marcador de etapas intermediárias de diferenciação muito utilizado na literatura como marcador para diferenciação de MC3T3-E1 (Lian et al., 1998). Os resultados mostram aumento na 
expressão de osteocalcina que chega a aproximadamente 50 vezes mais que o controle (não induzido) após seis dias da indução da diferenciação (Fig. 11).

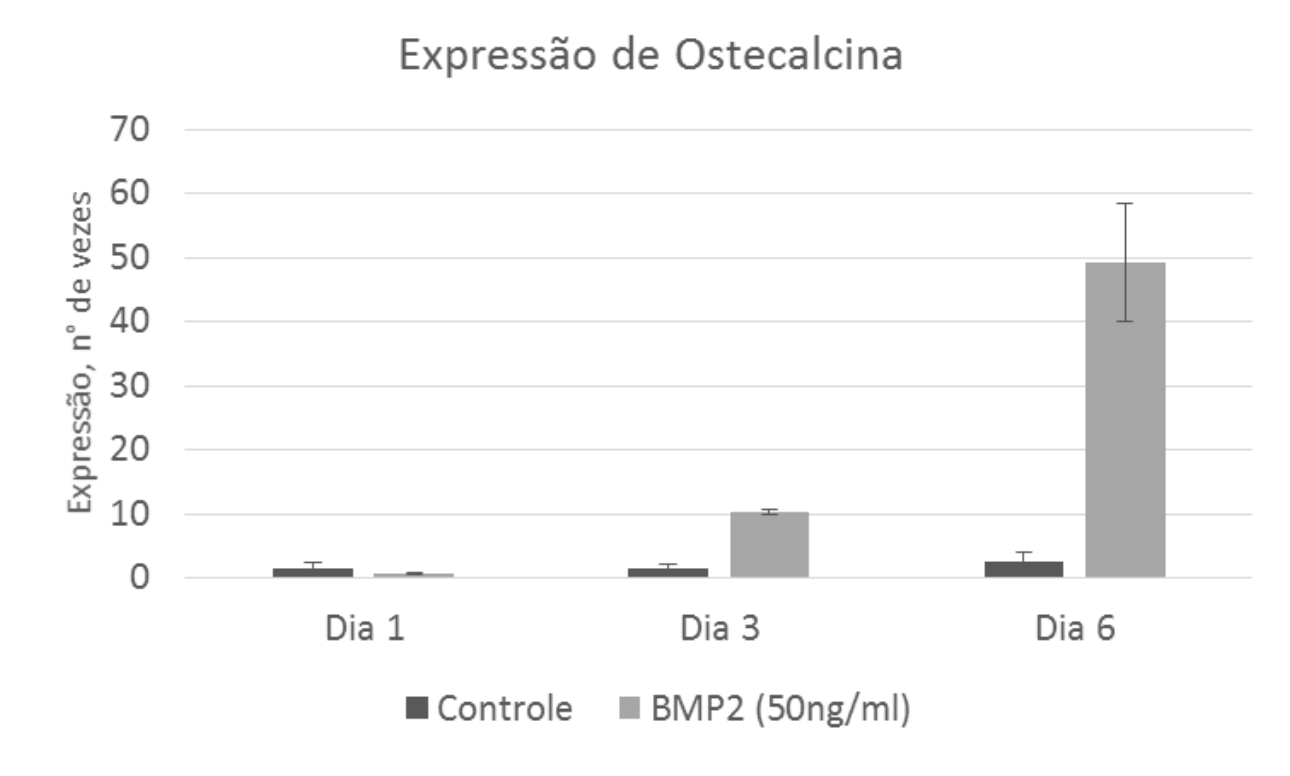

Figura 11. Expressão de osteocalcina após indução da diferenciação osteogênica. As células MC3T3-E1 em cultivo foram induzidas a diferenciação com meio osteogênico suplementado com 50ng/mL BMP2 por até três dias e posteriormente mantidas em meio osteogênico por até seis dias. $O$ nível de expressão gênica de OC foi medido por qPCR em um, três e seis dias após a indução. Controle: células MC3T3-E1 que foram mantidas em meio de crescimento por até seis dias.

Esse é mais um resultado que mostra que as células estavam na condição ideal para os estudos de diferenciação. Após analisarmos a ativação da via de BMP2, através da fosforilação das proteínas Smad 1/5/8 e da expressão de Osteocalcina, a etapa seguinte foi analisar se a utilização de BMP2 aumentava a deposição de matriz extracelular calcificada, etapa mais tardia da diferenciação. Os dados mostram que deposição de matriz calcificada aumenta após o tratamento com BMP2, de maneira dose dependente (Fig. 12). 
(A)

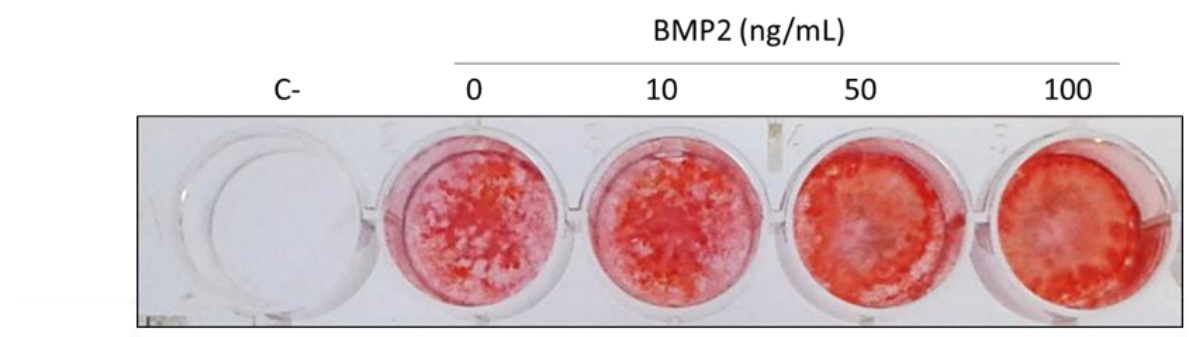

(B)

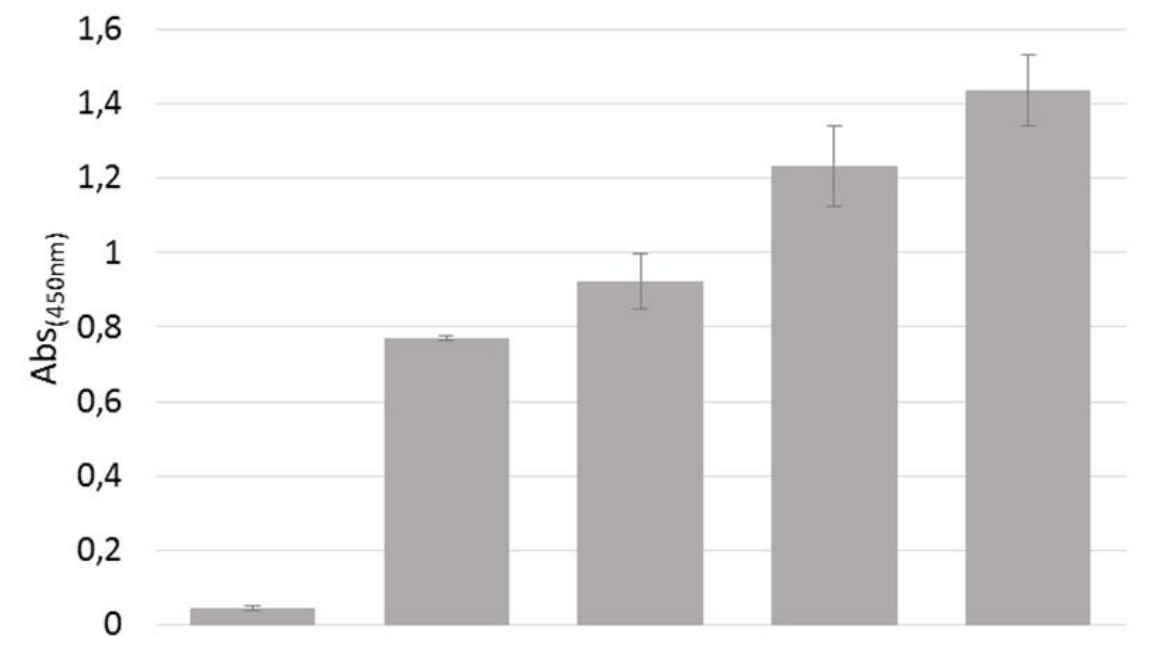

Figura 12. Tratamento com concentrações crescente de hr BMP2 e marcação de matriz calcificada. As células MC3T3-E1 foram mantidas por três dias em meio de crescimento (C-), meio osteogênico (0) ou meio osteogênico suplementado com BMP2 em diferentes concentrações (10, 50 e $100 \mathrm{ng} / \mathrm{mL})$. Após três dias, o meio foi substituído por meio de crescimento (C-) ou meio osteogênico fresco e as células foram mantidas em cultura até completarem doze dias de diferenciação. As células foram fixadas e coradas com Alizarin Red. (A) Imagem representativa e (B) quantificação da coloração por absorbância (450nm) de n=4.

A caracterização dos efeitos decorrentes do tratamento com doses crescentes de hrBMP2 foi importante para o desenvolvimento das etapas seguintes deste trabalho. Os experimentos mostram que as células respondem de maneira dose-dependente ao tratamento com BMP2, ou seja, quanto maior a dose de tratamento com BMP2, mais eficiente é o processo de diferenciação. Para os experimentos a seguir, definimos duas condições de diferenciação, dependendo do objetivo de cada experimento. A condição 1 (doses de 10 e $50 \mathrm{ng} / \mathrm{mL}$ de hrBMP2) foi utilizada em experimentos nos quais pretendemos modular o potencial de diferenciação celular, enquanto que a condição 2 (maiores doses -100 e $200 \mathrm{ng} / \mathrm{mL}$ de $\mathrm{hrBMP} 2$ ) foi utilizada para experimentos nos quais pretendemos analisar a resposta celular ao estímulo de diferenciação. 


\subsection{Efeitos de tratamentos redox na diferenciação osteogênica}

Após a caracterização do processo de diferenciação osteogênica induzido por hrBMP2, a etapa seguinte deste trabalho visou analisar se tratamentos com oxidantes e redutores eram capazes de inibir ou estimular a diferenciação.

Para isso, tratamos as células com $\mathrm{N}$-acetilcisteína (NAC) e peróxido de hidrogênio (um redutor e um oxidante, respectivamente) antes de induzir as células à diferenciação. A NAC é uma molécula amplamente utilizada na literatura como um "antioxidante", inclusive em modelos de estudo relacionados a homeostase redox em células-tronco (Ito et al., 2004). O peróxido de hidrogênio tem sido utilizado com o objetivo de aumentar o conteúdo de oxidantes intracelulares (uma vez que ele atravessa a membrana plasmática), para estudar os efeitos deletérios de altas concentração dessa molécula, bem como em trabalhos que o testa em baixas doses, como uma possível molécula sinalizadora (Day et al., 2012).

As células foram submetidas aos tratamentos com peróxido de hidrogênio (5 e $10 \mu \mathrm{M})$ e NAC (1 a $10 \mathrm{mM}$ ) e posteriormente induzidas a diferenciação para avaliarmos o efeito dos tratamentos redox. O tratamento com NAC atrasou ou impediu a diferenciação osteogênica, principalmente nas concentrações de 5 e $10 \mathrm{mM}$. Além disso, o tratamento com peróxido de hidrogênio nas concentrações testadas parece não influenciar no processo de diferenciação (Fig. 13). Isso indica que a condição redox intracelular pode ser uma variável importante para o processo de diferenciação osteogênica, pelo menos nas condições experimentais analisadas. 


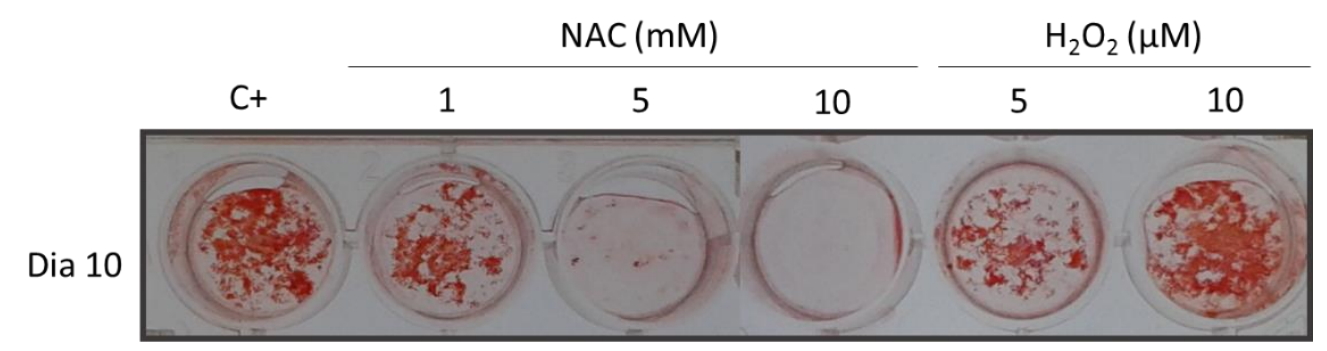

Dia 12

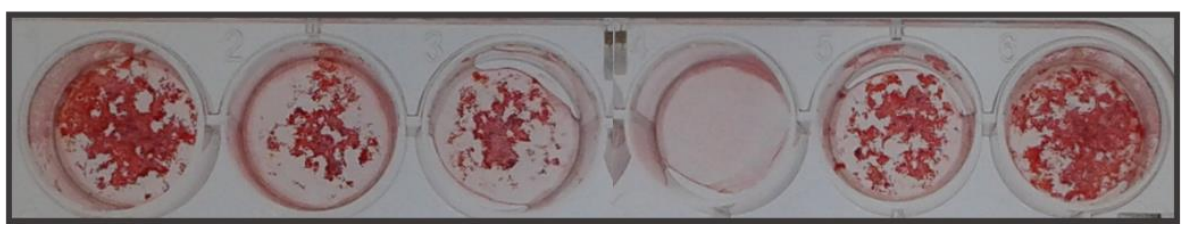

Figura 13. Diferenciação osteogênica em células tratadas com NAC e peróxido de hidrogênio. As células MC3T3-E1 em cultivo foram tratadas por 45min com as doses e os compostos citados. Após o tratamento, o meio foi substituído por meio osteogênico suplementado com 10ng/ml BMP2, por três dias, e depois por meio oesteogênico até completar 10 e 12 dias. As células foram fixadas e coradas com Alizarin Red.

A outra hipótese para explicar esse resultado seria que a NAC é tóxica para as células, e que o tratamento poderia reduzir a viabilidade celular. Para testar essa hipótese, como controle, usamos as mesmas condições de tratamento para verificar seu efeito sobre a sobrevivência e proliferação celular. É importante lembrar que conforme as células diferenciam, suas taxas de proliferação geralmente diminuem, e por este motivo, os experimentos de viabilidade e proliferação celulares foram realizados por períodos de até 5 dias após o tratamento com peróxido de hidrogênio e NAC. Se a NAC causasse a morte das células ou a redução da proliferação logo nos primeiros dias de cultivo, seria esperado que um número menor de células estivesse apto a diferenciar, no experimento anterior. No entanto, os resultados mostram que os tratamentos com NAC não alteram os índices de proliferação e sobrevivência, o que indica que a redução na deposição de matriz extracelular calcificada, vista no experimento anterior, é resultado da redução no potencial de diferenciação osteogênica. (Fig. 14). 
(A)

\section{Curva de crescimento}

1

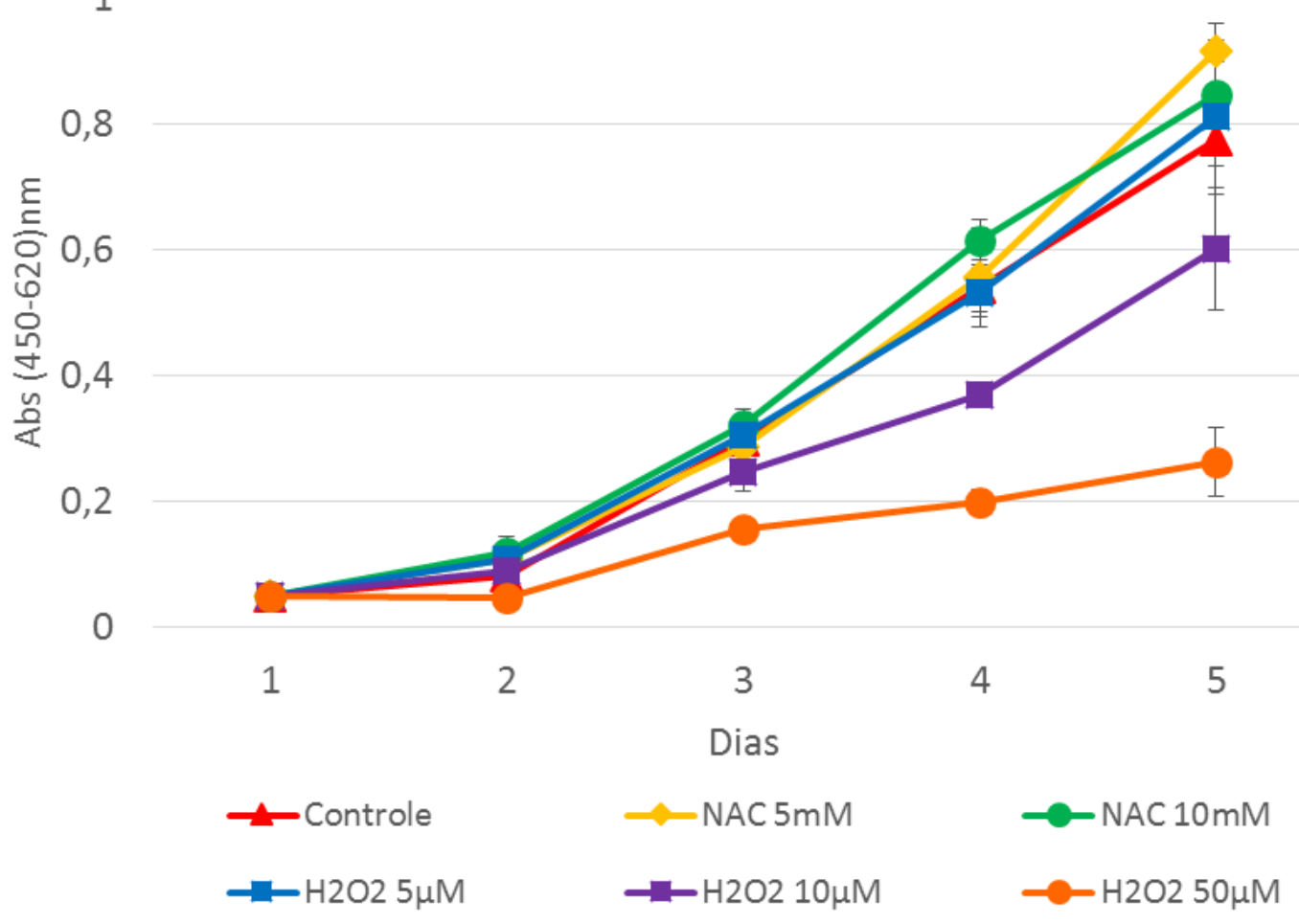

(B)

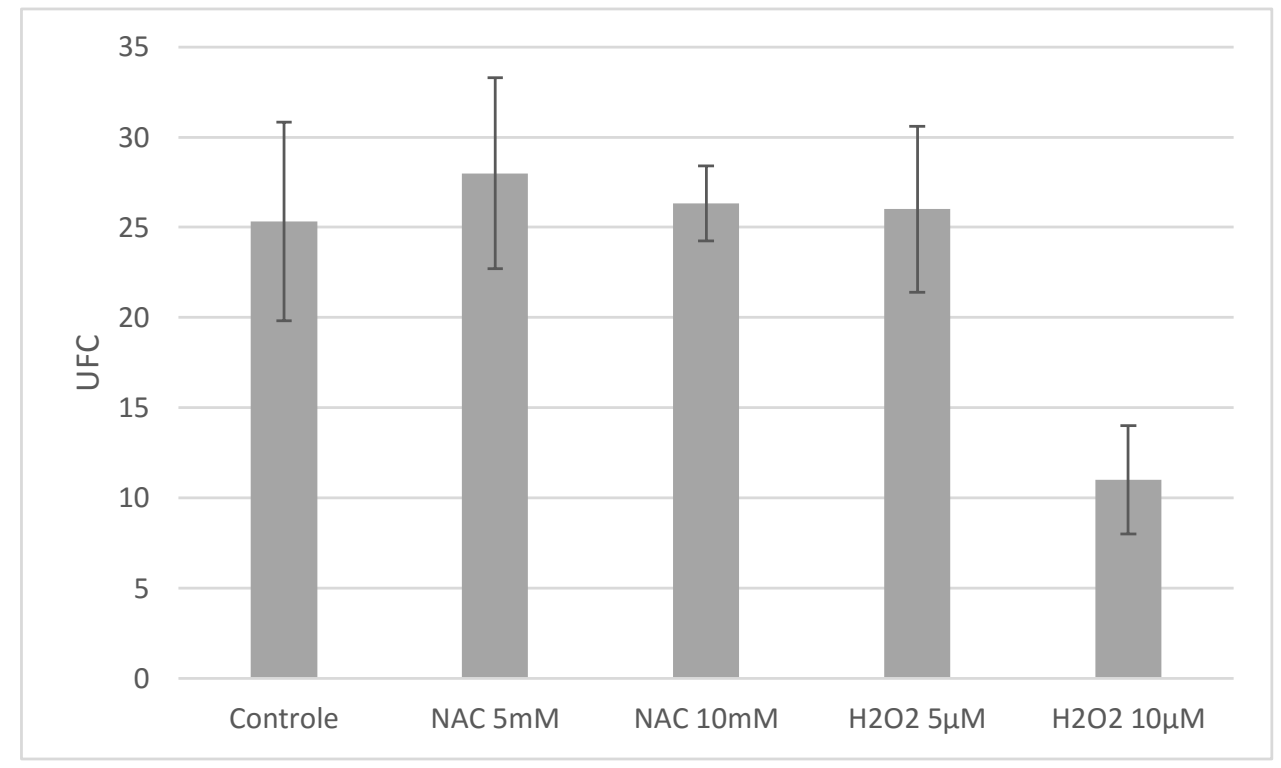

Figura 14. Efeito dos tratamentos com oxidantes e antioxidantes na sobrevivência e proliferação celular. (A) A proliferação celular foi acompanhada pela técnica de XTT. As células cultivadas em placas de 96 poços foram tratadas com os compostos e concentrações indicadas por 45 minutos e mantidas em meio de crescimento por quatro dias. A cada dia foi coletado um conjunto de dados $(n=5)$, utilizando o reagente de XTT, incubado por $4 \mathrm{~h}$ a $37^{\circ} \mathrm{C}$. A leitura da absorbância foi realizada a 450nm. (B) A sobrevivência celular foi acompanhada pela capacidade das células em sobreviver ao tratamento e formar colônias. As células foram tratadas por 45 minutos nas condições indicadas e posteriormente, mantidas em meio de crescimento por cinco dias, fixadas e coradas com Crystal Violet (Sigma) e as colônias foram observadas e contadas em estereomicrocópio. Foi considerada colônia um agrupamento isolado de células, com mais de cinquenta células. UFC: Unidade Formadora de Colônia. 
Neste experimento, podemos ver que as células tratadas com peróxido de hidrogênio apresentam reduzidas taxas de proliferação a partir de concentrações de 10 $\mu \mathrm{M}$. O peróxido de hidrogênio é geralmente associado a parada no ciclo celular, o que explica esse efeito durante o cultivo de células em proliferação, entretanto, o tratamento com peróxido de hidrogênio não deve causar o mesmo efeito em células em diferenciação porque, como citado anteriormente, essas células não apresentam altas taxas de proliferação.

Os tratamentos com peróxido de hidrogênio e com NAC são muito utilizados para estudos como o proposto nessa dissertação, embora no caso de NAC os mecanismos subjacentes às suas ações ainda não sejam totalmente conhecidos. Provavelmente, NAC interfere em diferentes razões de tiol (RSH) e dissulfeto (RSSR), tanto protéicos como para moléculas de baixo peso molecular como glutationa (GSH). Isso porque é improvável que NAC alcance altas concentrações intracelulares, capazes de competir com moléculas biológicas por oxidantes (Forman, Traber e Ursini, 2014). Além disso, a reatividade de tióis de baixo peso molecular como NAC com oxidantes, como peroxido de hidrogênio, é muito baixa (revisado por Netto e Antunes, 2016).

Para confirmar nossos resultados sobre o efeito repressor de antioxidantes sobre a diferenciação celular, utilizamos catalase conjugada com PEG (polyethylene glycol), aqui denominado PEG-catalase. As moléculas de PEG são lipossolúveis e capazes de cruzar a membrana plasmática, facilitando a entrada da catalase nas células. A catalase, por sua vez, decompõe peróxido de hidrogênio intracelular e, dessa maneira, torna o ambiente intracelular menos oxidativo. A utilização desse composto é uma estratégia interessante para estudar os efeitos específicos do peróxido de hidrogênio intracelular. 
O experimento para deteç̧ão da catalase mostra que 45 minutos de incubação são suficientes para que a PEG-catalase passe pela membrana plasmática e, provavelmente, possa atuar na remoção de $\mathrm{H}_{2} \mathrm{O}_{2}$ (Fig. 15).

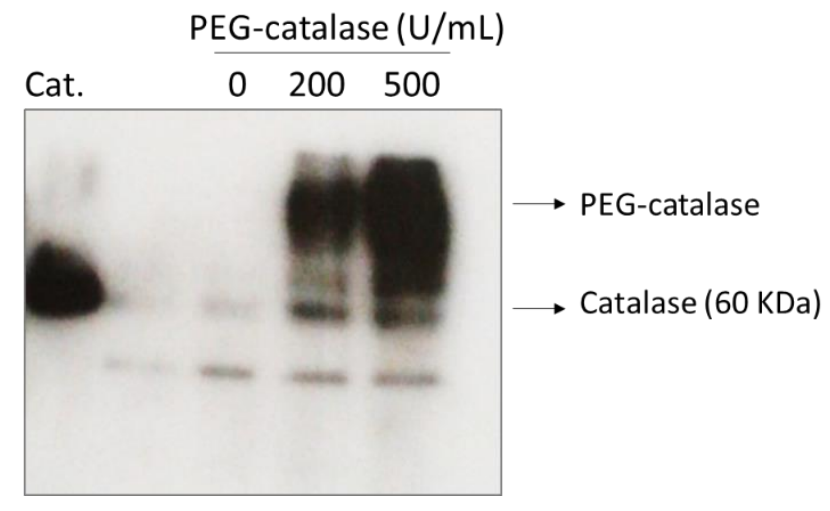

\begin{abstract}
Figura 15. Marcação de catalase intracelular após tratamento com PEGcatalase.

As células foram tratadas com 200 e $500 \mathrm{U} / \mathrm{ml}$ PEG-catalase por 45 minutos. 0 extrato celular foi submetido a ensaio de western blot e a membrana foi marcada com anticorpo anti-catalase. Cat.: catalase bovina
\end{abstract}

A seguir, avaliamos o efeito do tratamento com PEG-catalase na inibição da diferenciação osteogênica. Interessantemente, assim como acontece com o tratamento com NAC, o tratamento com PEG-catalase reduz o potencial de diferenciação das células (Fig 16).

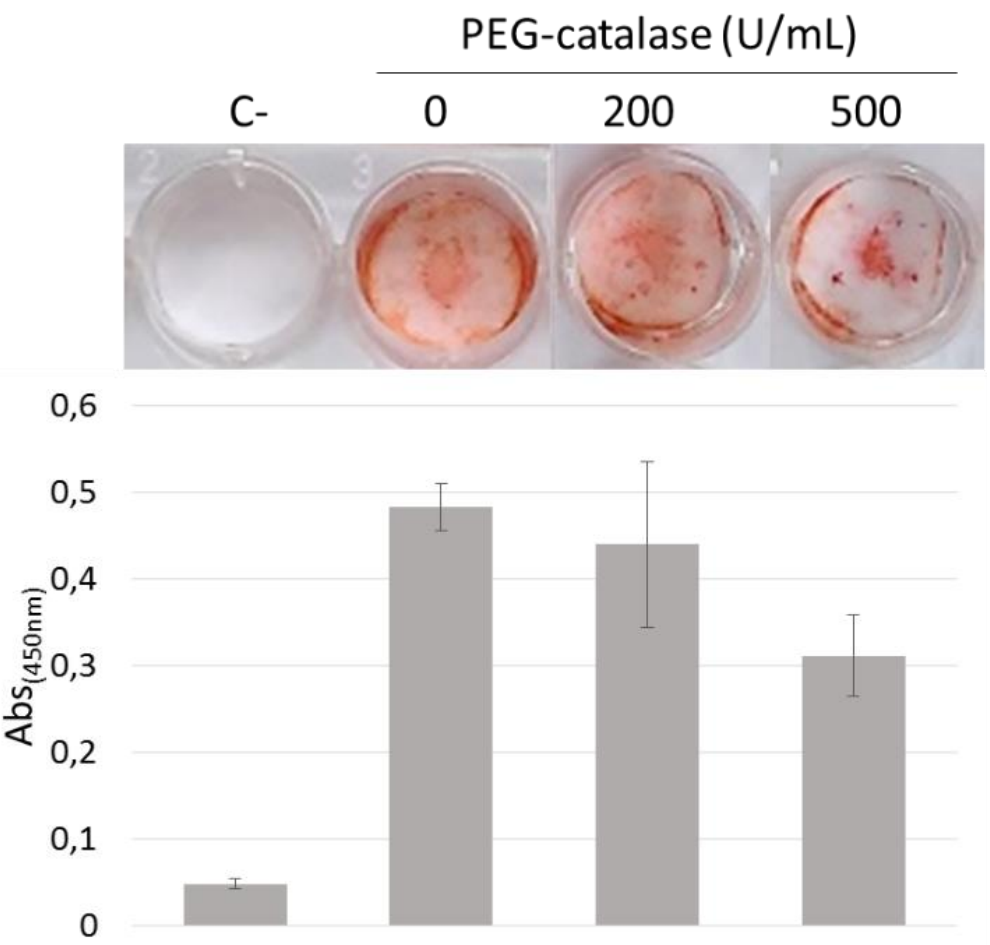

Figura 16. Diferenciação celular após tratamento com PEG-catalase. As células MC3T3-E1 em cultivo foram tratadas com as concentrações indicadas de PEG-catalase por 45 minutos. Em seguida, o meio de 
tratamento foi substituído por meio osteogênico suplementado com 10ng/ml de BMP2 por três dias e posteriormente por meio osteogênico até completar 14 dias. As células foram coradas com Alizarin Red. (A) Imagem representativa e (B) quantificação da coloração por absorbância $(450 \mathrm{~nm})$ de $n=4$

Como um controle para esse experimento, realizamos testes de diferenciação apenas com PEG, mas não houve alteração no potencial de diferenciação.

Até este momento, nossos resultados sugerem que os tratamentos com antioxidantes reduzem o potencial de diferenciação osteogênica das células MC3T3-E1. Os mecanismos pelos quais a modulação por antioxidantes pode acontecer ainda não são bem conhecidos. A etapa seguinte, então, foi tentar entender parte desse mecanismo, e para isso optamos por analisar se esses tratamentos inibem a fosforilação do complexo Smad 1/5/8. Com este experimento, gostaríamos de investigar se os antioxidantes podem agir antes ou depois da ativação das vias de sinalização por BMP2.

Testamos a fosforilação das proteínas Smad 1/5/8 decorrentes do estímulo com $50 \mathrm{ng} / \mathrm{mL}$ hrBMP2, em células pré-tratadas com peróxido de hidrogênio (10 e 50 M), NAC (5 e 10mM) e PEG-catalase (200 e $500 \mathrm{U} / \mathrm{mL}$ ). Os resultados mostram que o tratamento com BMP2 por uma hora (controle) promove fosforilação do complexo Smad 1/5/8, sem alterar a concentração de Smad 1. Quando as células são pré-tratadas com as doses mais elevadas de PEG-catalase ou NAC, é possível ver menores níveis de fosforilação, principalmente no tratamento com 10mM NAC (Fig. 17). 


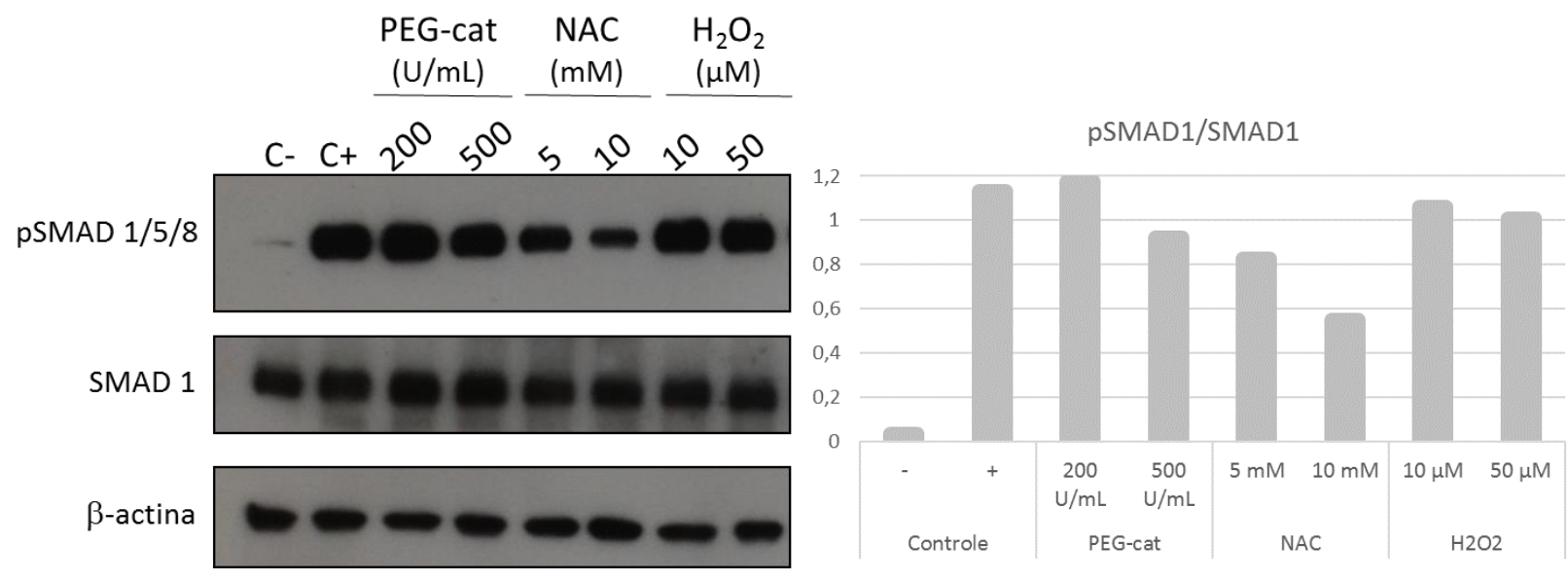

Figura 17. Fosforilação de Smad 1/5/8 após tratamentos com oxidantes e antioxidantes.

Western blot de células MC3T3-E1 pré-tratadas com compostos antioxidantes e peróxido de hidrogênio e posteriormente tratadas com 50ng/ml BMP2.

(C-) Controle negativo, sem BMP2; (C+) controle positivo, 50ng/ml BMP2 (sem pré-tratamento).

Os pré-tratamentos foram realizados por 45 minutos. Os anticorpos utilizados estão indicados a esquerda. A figura mostra o filme revelado (esquerda) e a quantificação relativa de bandas, razão entre a banda das formas fosforiladas pelas não-fosforiladas (direita).

Esses resultados reforçam que o estado redox intracelular pode interferir na sinalização que promove a diferenciação osteogênica. Nos experimentos mostrados até aqui, a presença de antioxidantes e, consequentemente, um ambiente intracelular mais redutor podem estar envolvidos com a inibição da diferenciação osteogênica.

\subsection{Resposta redox à diferenciação}

Para dar continuidade aos experimentos reportados anteriormente, o objetivo dos próximos experimentos foi tentar caracterizar a resposta endógena e fisiológica à indução da diferenciação com BMP2, no que se refere ao metabolismo redox.

Para responder a essa questão, optamos por quantificar a produção de peróxido de hidrogênio após o estímulo à diferenciação. Escolhemos o peróxido de hidrogênio como molécula alvo porque os resultados anteriores mostram que o tratamento com catalase (que detoxifica especificamente o peróxido de hidrogênio) também reduz o potencial de diferenciação osteogênico. 
No entanto, a quantificação da produção de peróxido é ainda hoje um desafio para os pesquisadores da área redox. A maioria das técnicas disponíveis não é específica ou sensível o suficiente para detectar alterações nas concentrações de peróxido de hidrogênio em níveis próximos ao fisiológico (Winterbourn, 2014).

A primeira tentativa foi padronizar a transfecção das células com um plasmídeo que expressa uma sonda redox intracelular conhecida como HyPer, que ao reagir com peróxido de hidrogênio, sofre alterações em sua fluorescência (Belousov et al., 2006). No entanto, a transfecção mostrou-se de baixa eficiência, não obtivemos êxito em conseguir uma quantidade razoável de células transformadas com o referido plasmídeo, o que impossibilitou o uso desta técnica.

Optamos então por utilizar a técnica de Amplex Red e HRP para detectar o possível aumento nos níveis de peróxido de hidrogênio. O ensaio enzimático de Amplex Red com HRP é bastante específico para detecção de peróxido de hidrogênio, possui sensibilidade para concentrações na faixa de $1-4 \mu \mathrm{M}$ e pode ser realizado a partir do sobrenadante ou do extrato celular. As células foram tratadas com BMP2 por 1 h ou com meio osteogênico por 16h, e então foi feita a quantificação de peróxido de hidrogênio no sobrenadante (Fig. 18). Entretanto, através desses experimentos, não foi possível quantificar o aumento geral da produção de peróxido de hidrogênio após estímulo com BMP2. 

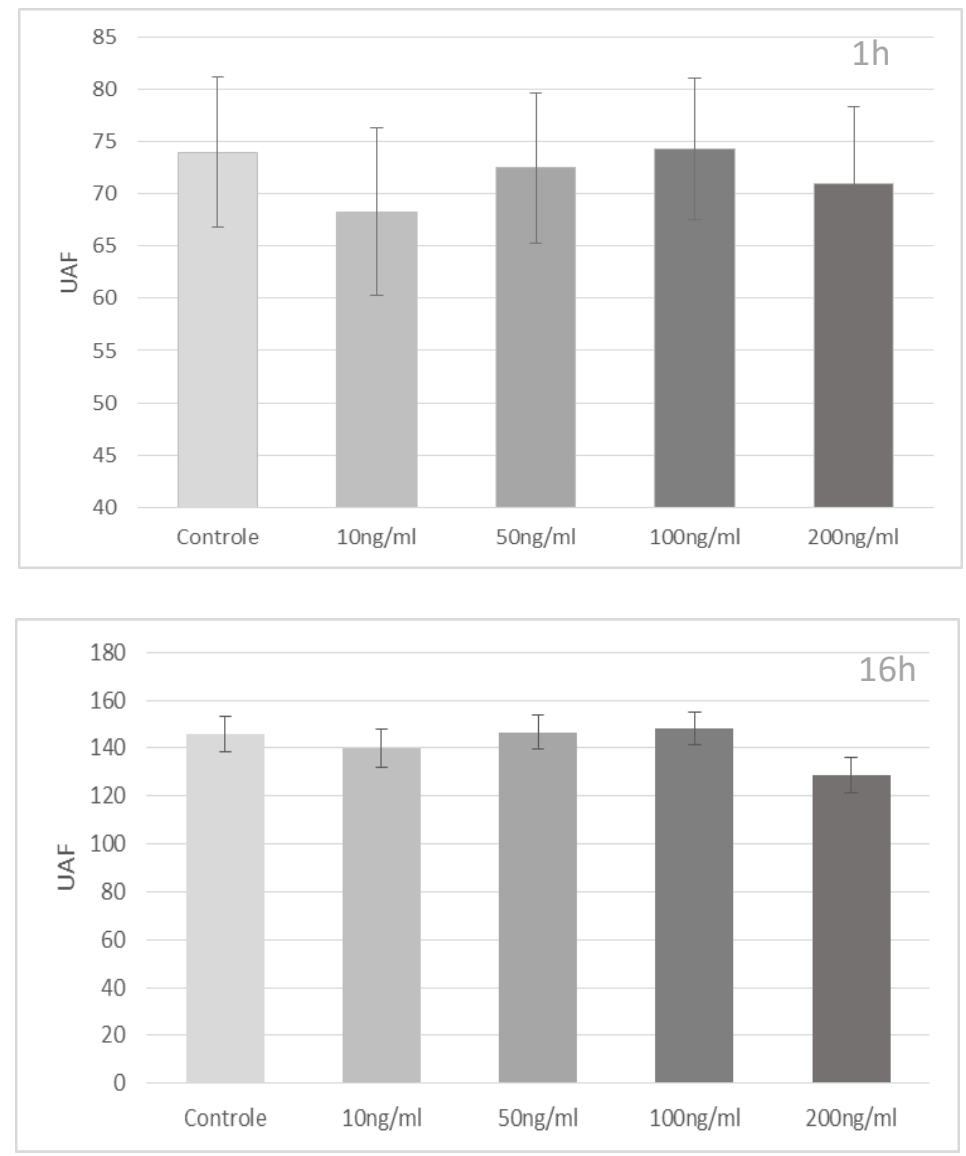

Figura 18. Quantificação de peróxido de hidrogênio após tratamento com BMP2. As células MC3T3-E1 em cultivo foram tratadas com meio osteogênico suplementado com 10, 50, 100 ou $200 \mathrm{ng} / \mathrm{ml}$ de BMP2 por uma hora (superior) ou dezesseis horas (inferior). O sobrenadante foi incubado na presença de 100uM Amplex Red e $0,2 \mathrm{U} / \mathrm{ml} \mathrm{HRP}$ e a reação foi incubada por $30 \mathrm{~min}$. A leitura de fluorescência foi realizada por espectrofluorímetro, com excitação em 560nm e emissão em 590nm. Controle: células MC3T3-E1 que foram mantidas em meio de crescimento durante todo o experimento.

Algumas das explicações para este resultado podem ser que um aumento de peróxido de hidrogênio não torne o ambiente intracelular todo mais oxidado, mas que seja um aumento compartimentalizado, concentrado em regiões próximas a seus sítios de produção. Além disso, a célula possui múltiplos sistemas enzimáticos eficientes na detoxificação de peróxido de hidrogênio, que podem ser reagir com essa molécula de maneira a competir com o reagente de detecção.

Passamos então a analisar de maneira indireta a possibilidade de existir uma resposta redox associada à indução da diferenciação, principalmente com a produção 
de peróxido de hidrogênio. A etapa seguinte, então, foi analisar uma fonte produtora de peróxido de hidrogênio, a NOX4, que forma um complexo protéico responsável pela produção da molécula, ativado por fatores de crescimento e citocinas (Bedard e Krause, 2007), e que tem sua expressão ativada em modelos de diferenciação osteogênica e calcificação de células do tecido vascular, que ocorrem por estímulo de BMP2 (Liberman et al., 2011; Mandal et al., 2011).

As células foram mantidas em meio de diferenciação com hrBMP2 por até 6 dias e os níveis de expressão de NOX4 foram medidos após um, três e seis dias de diferenciação (Fig 19). O gráfico mostra o aumento nos níveis de NOX4 após um dia de tratamento com BMP2, e retorno aos níveis comparados ao controle após esse momento.

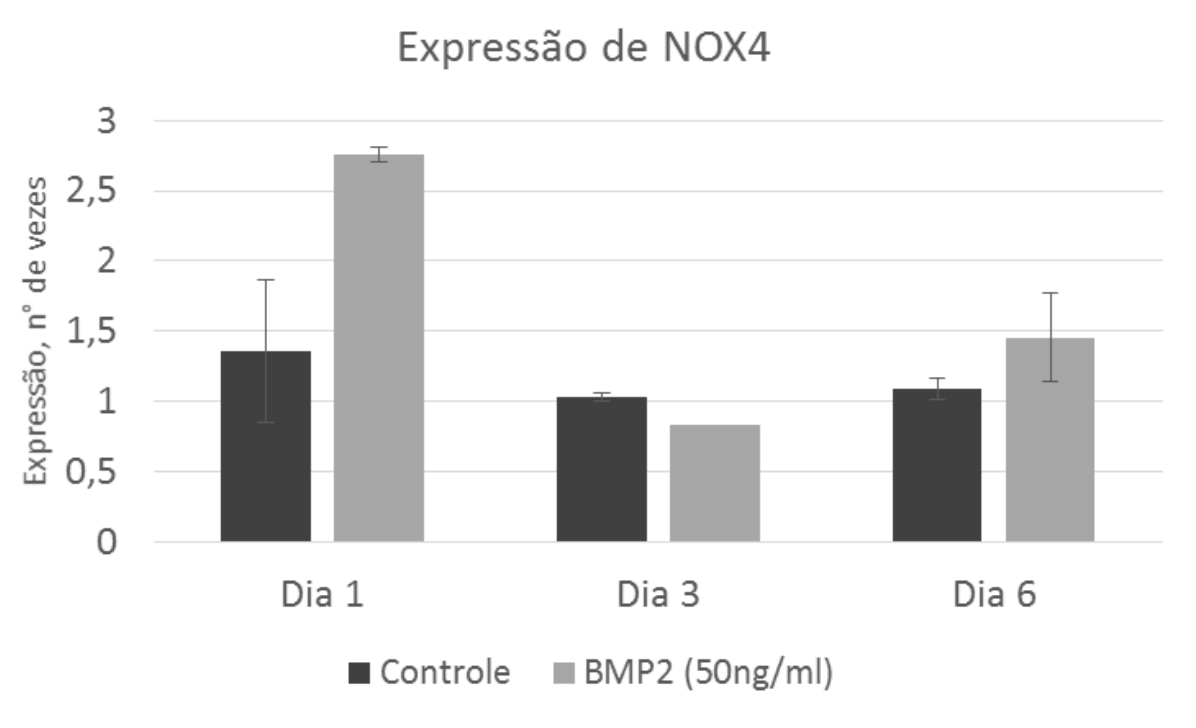

Figura 19. Expressão relativa de nox4 em células MC3T3-E1 após estímulo osteogênico. As células MC3T3-E1 em cultivo foram induzidas a diferenciação com meio osteogênico suplementado com $50 \mathrm{ng} / \mathrm{mL}$ BMP2 por até três dias e posteriormente mantidas em meio osteogênico por até seis dias. $O$ nível de expressão gênica de Nox4 foi medido por qPCR em um, três e seis dias após a indução. Controle: células MC3T3-E1 que foram mantidas em meio de crescimento durante os seis dias. 
Esse resultado indica que pode haver indução da expressão de NOX4 após o tratamento com BMP2. Essa indução da expressão pode, em última instância, estar relacionada ao aumento na produção de peróxido de hidrogênio intracelular, desde que esse aumento da expressão traduza-se em mais moléculas de NOX4 ativas nas células.

Apesar de não termos detectado variações nos níveis de peróxido de hidrogênio, optamos por investigar a modulação das proteínas envolvidas em sua detoxificação. Isso se justifica por dois motivos:

1. Se o estímulo à diferenciação promove aumento da produção de peróxido intracelular, as proteínas envolvidas em sua detoxificação também devem sofrer algum tipo de modulação, influenciada pelo aumento de seu substrato;

2. Dados da literatura mostram que a sinalização por peróxido de hidrogênio depende de algumas condições importantes: aumento localizado da concentração de peróxido e inativação das proteínas responsáveis por sua remoção. Isso porque a reatividade do peróxido de hidrogênio com as peroxidases é muito maior do que com outros alvos passíveis de modulação por oxidação (revisado por Netto e Antunes, 2016).

As Prxs tem sido implicadas em sinalização redox (Rhee, Chae e Kim, 2005; Winterbourn e Hampton, 2008; Netto e Antunes, 2016), principalmente sofrendo oxidação ou fosforilação, que as inativam de maneira reversível ou pela interação física com proteínas redox-sensíveis. Optamos, nesse momento, por investigar as duas Prx que tem sido mais associadas a modelos de sinalização redox, a $\operatorname{Prx} 1$ e 2. Investigamos essas Prxs em nosso sistema primeiramente pela análise de sua expressão gênica durante a diferenciação, para identificarmos se havia a indução da expressão ao longo do processo e os resultados mostram que não houve alteração significativa na expressão 
de Prx 1 e 2 durante a diferenciação, nem mesmo no dia 1, quando é visto aumento na expressão de NOX4 (Fig. 20).

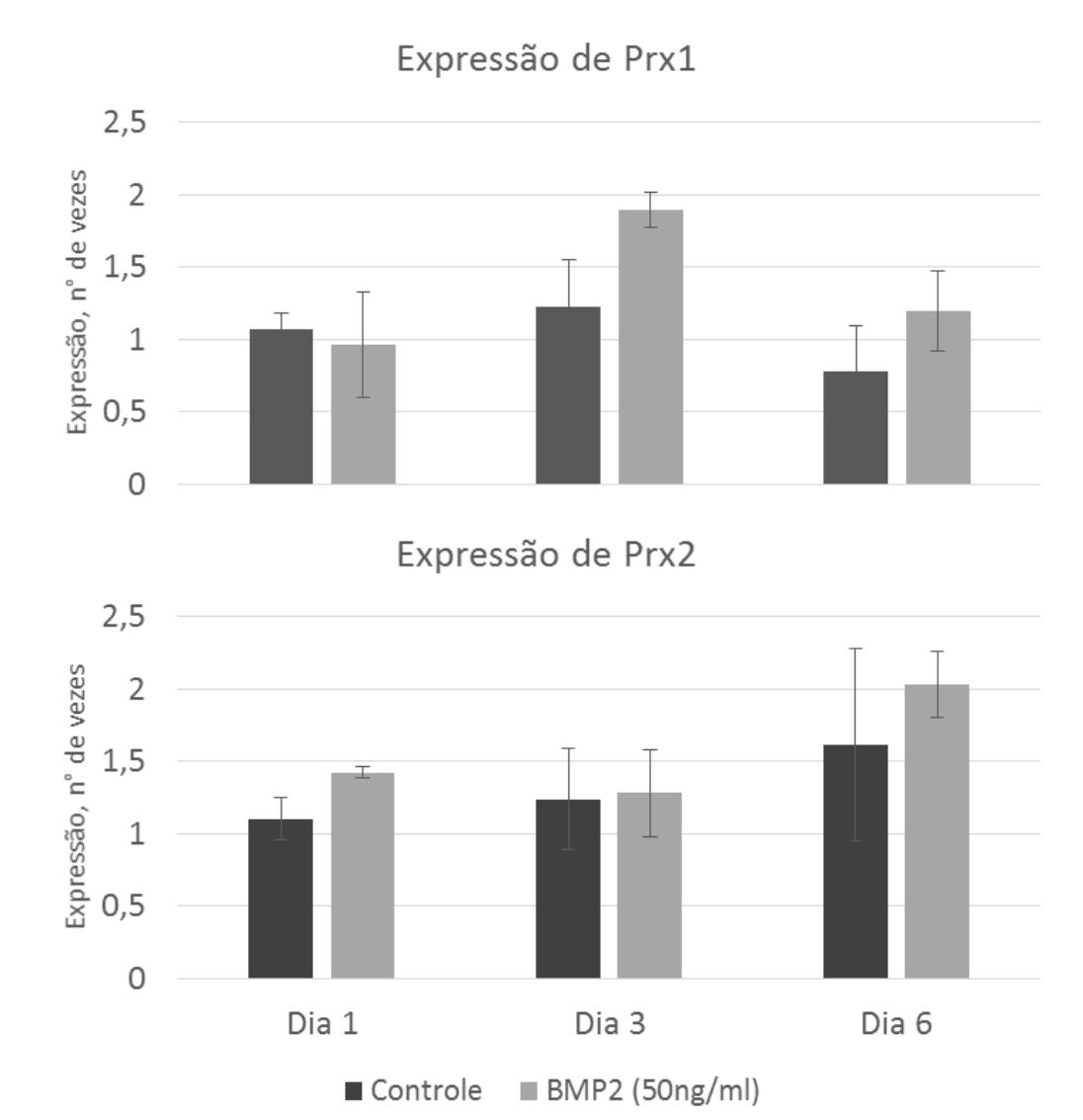

Figura 20. Expressão relativa de prx1 e prx2 em células MC3T3-E1 após estímulo osteogênico. As células MC3T3-E1 em cultivo foram induzidas a diferenciação com meio osteogênico suplementado com $50 \mathrm{ng} / \mathrm{mL}$ BMP2 por até três dias e posteriormente mantidas em meio osteogênico por até seis dias. $O$ nível de expressão gênica de Prx1 (superior) e Prx2 (inferior) foi medido por qPCR em um, três e seis dias após a indução. Controle: células MC3T3-E1 que foram mantidas em meio de crescimento durante os seis dias.

É importante lembrar que as alterações vistas ao nível de expressão gênica podem não ser vistas ao nível de proteínas ativas, funcionais. A partir desse resultado, decidimos investigar então o estado de oxidação de Prx após a indução da diferenciação osteogênica. Optamos por testar inicialmente a Prx1, por ser a Prx mais frequentemente associada a modelos de sinalização redox, juntamente com a Prx2.

Após o tratamento com BMP2, utilizamos a técnica de Western Blot redox para verificar o estado de oxidação da Prx1 (Fig. 21). Os resultados mostram que os níveis de 
Prx1 oxidada (visualizada como um dímero em SDS-PAGE não redutor) aumentam após o tratamento com BMP2, de maneira dose-dependente.
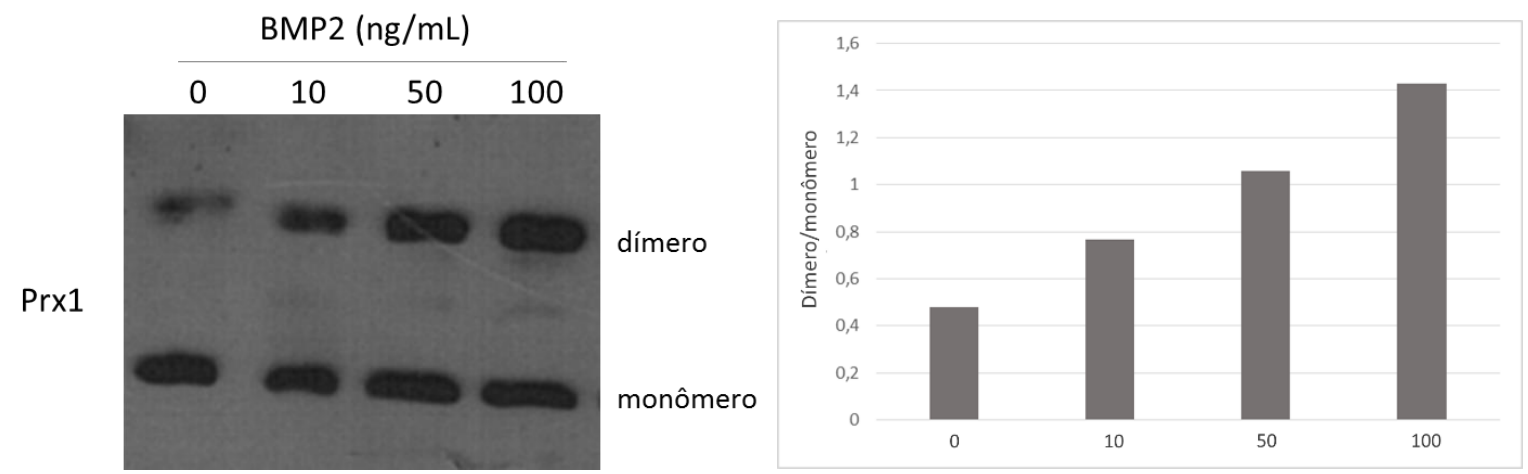

Figura 21. Western blot anti-peroxiredoxina 1. As células MC3T3-E1 em cultivo foram tratadas com meio osteogênico suplementado com $0,10,50$ ou $100 \mathrm{ng} / \mathrm{mL}$ BMP2 por $1 \mathrm{~h}$. As células foram então lisadas na presença de TCA e o extrato celular foi submetido a técnica de Western Blot redox. A figura mostra o filme revelado (esquerda) e a quantificação relativa de bandas, razão entre a banda do dímero pelo monômero (direita).

Esses resultados sugerem mais uma vez, de maneira indireta, a participação de peróxido de hidrogênio e de $\operatorname{Prx}$ na diferenciação osteogênica. A oxidação da Prx durante a diferenciação induzida por BMP2 é mais uma evidência da participação de processos redox na via de diferenciação osteogênica e está de acordo com os diversos mecanismos de sinalização redox com a participação de Prx já descritos.

A partir desses resultados, ainda não é possível inferir se o peróxido de hidrogênio reage diretamente com outros alvos após a inativação de Prx ou se as reações redox se dão por meio da interação de algumas proteínas com as Prxs ou mesmo Trxs. 


\section{Discussão}

Atualmente, é bem aceito que modificações redox são eventos regulatórios importantes em funções celulares, como proliferação e diferenciação. Em termos gerais, a maioria dos trabalhos na área descreve que baixos níveis de ROS são necessários para manutenção de células-tronco em estado indiferenciado, enquanto que o aumento na produção de ROS (bem como a alteração do metabolismo para uma condição mais oxidativa) está relacionado à diferenciação celular (Yanes et al., 2010; Zhang et al., 2012; Ito e Suda, 2014).

As células murinas MC3T3-E1 têm sido extensivamente utilizadas na literatura como um modelo de estudo para diferenciação osteogênica. No entanto, essas células já são pré-osteoblastos, o que restringe, de certa forma, o estudo dos efeitos de processos redox na diferenciação às etapas mais tardias do processo. Uma forma de resolver essa questão seria utilizar mESC, que nos daria uma visão mais completa de todo o processo de diferenciação e também a possibilidade de investigar a participação de processos redox em suas etapas mais iniciais. Durante o período deste trabalho, padronizamos a diferenciação osteogênica de CTE de camundongos, em condições semelhantes às usadas na diferenciação de MC3T3-E1. Entretanto, optamos por explorar melhor o modelo em MC3T3-E1 antes de investir em um novo modelo celular. O estudo de processos redox na diferenciação osteogênica com o uso de CTE é uma perspectiva futura.

Com as células aqui utilizadas, caracterizamos a diferenciação através da resposta a indução com BMP2, analisando expressão gênica, cascatas de fosforilação e 
deposição de matriz extracelular calcificada, e as células apresentaram alto potencial de proliferação e diferenciação, vistos através do aumento da fosforilação do complexo Smad 1/5/8, da expressão de osteocalcina e da deposição de matriz extracelular calcificada, caracterizando um modelo apropriado para as análises aqui propostas.

A relação entre ROS e a diferenciação osteogênica ainda é controversa na literatura. De acordo com Salim e col. (2004), a exposição de MSC cultivadas in vitro a uma condição de anóxia, que altera o balanço redox das células, regula negativamente a expressão de BMP2 e Runx2, inibindo sua diferenciação. Em outros trabalhos, foi visto que o tratamento de células com doses elevadas de peróxido de hidrogênio (125 $500 \mu \mathrm{M})$, antes ou logo após a indução da diferenciação, pode reduzir a capacidade ou retardar o processo de diferenciação osteogênica (Arai et al., 2007; Chen et al., 2008). Isso pode ser explicado porque diante de altas concentrações de oxidantes, podem ocorrer danos celulares e alteração em sua fisiologia, como por exemplo, parada do ciclo celular, aumento da expressão de proteínas antioxidantes e de reparo, entre outros.

Para investigar a importância de processos redox como mecanismo subjacente a diferenciação osteogênica, optamos por tratar as células com moléculas com capacidade oxidante e antioxidante. Escolhemos, num primeiro momento, NAC e peróxido de hidrogênio para os tratamentos. Neste trabalho, vimos que o tratamento com NAC resultou na diminuição do potencial de diferenciação osteogênico, detectado pela diminuição da fosforilação de Smad 1/5/8 e pela diminuição na deposição de matriz extracelular calcificada. Já o tratamento com peróxido de hidrogênio nas condições experimentais por nós utilizadas, apesar de poder diminuir a proliferação celular, não alterou o potencial de diferenciação. 
Mandal e colaboradores (2011), analisaram a influência de peróxido de hidrogênio produzido por NOX4 sobre a transcrição de BMP-2 e a diferenciação osteogênica de pré-osteoblastos de camundongos, e mostraram que esse oxidante em pode ter participação importante para promover a osteodiferenciação (Mandal et al., 2011). Neste trabalho, apesar dos autores já explorarem a ideia da produção de peróxido de hidrogênio como decorrência do estímulo com BMP2, nada foi feito para explicar a possível participação de peroxiredoxinas no processo.

As ROS estão relacionadas também a modulação da diferenciação osteoclástica, atuando como um importante mediador da via de sinalização de TRAF (TNF receptorassociated factor ) 6, Rac1 e Nox1 e estimulando a diferenciação de osteoclastos (Lee et al., 2005).

Os resultados sutis do tratamento com peróxido de hidrogênio para a diferenciação podem ser explicados pela falta de especificidade que as metodologias de análise trazem, no sentido de mimetizar a compartimentalização que é esperada em condições de sinalização redox. Nos trabalhos que mostram sua importância para sinalização celular, é visto que o aumento de peróxido de hidrogênio parece ser localizado, restrito a subcompartimentos celulares. Uma das explicações para esse aumento localizado é a hipótese de que é necessário que o peróxido de hidrogênio alcance concentrações que permitam que ele reaja com cisteínas proteicas que tem baixa reatividade com o peróxido de hidrogênio (revisado por Netto e Antunes, 2016).

Nossos resultados sugeriram que processos redox parecem estar envolvidos em diferenciação celular. Como desdobramentos desses resultados, algumas questões 
emergiram: qual ou quais seriam as moléculas relevantes para esse processo e através de qual mecanismo elas atuariam?

O peróxido de hidrogênio tem sido frequentemente descrito como uma molécula sinalizadora, apresentando propriedades compatíveis com essa função. 0 peróxido de hidrogênio é uma molécula relativamente estável, difusível, pouco reativa, que pode ser produzida por diversas enzimas intracelulares (Veal e Day, 2011). Para testar a importância do peróxido de hidrogênio, optamos por testar a PEG-catalase, como uma molécula "antioxidante". Os resultados com a PEG-catalase mostram também a redução do potencial de diferenciação, entretanto, de maneira menos intensa do que foi visto para NAC. Interessantemente, o tratamento com PEG-catalase não leva a diminuição expressiva na fosforilação das proteínas Smad1/5/8. Isso seria esperado para o caso de a via de fosforilação de Smad ser independente de ROS, enquanto o peróxido de hidrogênio, nesse contexto, poderia atuar em proteínas secundárias, como Akt quinase, por exemplo.

É interessante notar que duas moléculas com papel "antioxidante" geram resposta final semelhante, mas, provavelmente, por mecanismos diferentes. As vias normalmente afetadas por NAC são geralmente diferentes das afetadas por PEGcatalase. O mecanismo da NAC é relacionado ao metabolismo de tióis, por se tratar de uma fonte de cisteínas, o que pode aumentar o pool de glutationa reduzida, capaz de atuar redução de dissulfetos protéicos, entre outras funções. Já a PEG-catalase atua diretamente na remoção de peróxido de hidrogênio, graças a especificidade da enzima (Fig. 22). 


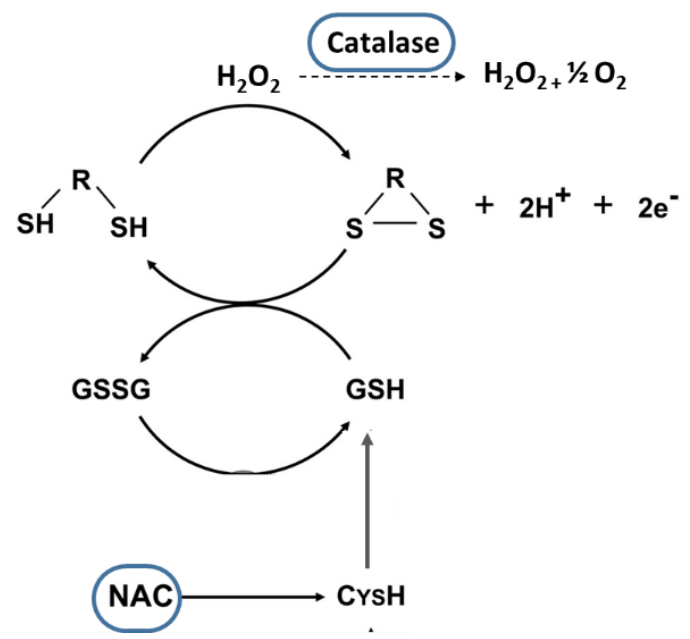

Figura 22. Modelo da atuação de NAC e catalase em vias bioquímicas. A NAC atua principalmente como doador de cisteínas para síntese de glutationa, enquanto a catalase atua diretamente na detoxificação de peróxido de hidrogênio.

A etapa seguinte deste trabalho foi testar a resposta fisiológica das células à indução com hrBMP2, especificamente com relação ao metabolismo redox.

Diante das evidências anteriores, iniciamos pela tentativa de medir a produção de peróxido de hidrogênio após o estimulo à diferenciação. No entanto, com a técnica utilizada, não foi possível quantificar diferenças na concentração de peróxido de hidrogênio intracelular. Algumas metodologias estão sendo desenvolvidas para tentar melhorar a especificidade e eficiência na quantificação de tal molécula, como é o caso da HyPer (Belousov et al., 2006), que poderia ser utilizada para quantificação de peróxido de hidrogênio intracelular, mas que tem sofrido críticas por ser sensível a alterações de pH e suscetível a redução por outros redutores intracelulares, por exemplo (Lukyanov e Belousov, 2014; Winterbourn, 2014).

Os modelos de sinalização redox na literatura indicam que as principais fontes de oxidantes envolvidos nesse processo são a mitocôndria e as NOX. O caso das NOX é ainda mais interessante para o nosso modelo de trabalho, porque a literatura mostra 
que a NOX4 pode ser ativada no contexto de calcificação de células do tecido vascular, induzido por BMP2 (Liberman et al., 2011).

Por este motivo, optamos por testar a indução da expressão da NOX4, e os dados de qPCR mostram aumento na expressão gênica de NOX4 após a indução com BMP2. Esse dado é condizente com outros trabalhos que mostram aumento da expressão ou atividade da NOX4 logo após o estímulo com fatores de crescimento ou diferenciação (Woo et al., 2010; Liberman et al., 2011; Yan, F. et al., 2014)

Neste ponto, uma opção interessante seria testar se a inibição das NOX causaria redução no potencial de diferenciação osteogênica. Entretanto, essa não é uma questão simples, pela ausência de inibidores químicos específicos para as NOX. Os principais protocolos utilizam DPI (diphenyleneiodonium) ou apocinina para promover a inibição de NOX, mas ambos não são inibidores específicos para NOX. O DPI é um inibidor não competitivo de flavoenzimas e causa alterações complexas na função celular; apocinina inibe NOX apenas quando ativada por outra enzima - Mieloperoxidase - em leucócitos, além de variar em eficiência e potência entre tipos celulares (Aldieri et al., 2008; Wind et al., 2010). A melhor abordagem para resolver essa questão seria, então, a inibição da expressão gênica da NOX, por RNAi ou por knockout, por exemplo.

Dessa forma, optamos por investir em experimentos que possibilitassem inferir a importância do peróxido de hidrogênio de maneira indireta, pela modulação de Prx, por exemplo.

As Prxs são importantes na redução de peróxidos nos mais diversos contextos, inclusive no metabolismo de células-tronco (Cho et al., 2006; Kim et al., 2014). Para analisar a importância das ROS, bem como da regulação das Prxs, optamos por testar a 
expressão e modificação redox das duas Prxs mais abundantes e reativas do citosol. Os resultados mostraram que, apesar de não vermos indução na expressão gênica de Prx1 e Prx2, é possível ver aumento na oxidação de Prx1 com o tratamento com hrBMP2.

As Prxs tem sido correlacionadas a manutenção de estados de pluripotência em células-tronco em cultura pela diminuição de níveis intracelulares de peróxido. Célulastronco embrionárias Prx1-/- e Prx2-/- mostram níveis aberrantes de ROS e rapidamente perdem o estado de pluripotência, associado com diferenciação prematura, mas com fenótipo que pode ser revertido pelo tratamento com NAC (Kim et al., 2014).

Nesse contexto, é possível traçar diferentes cenários nos quais oxidantes poderiam ter papel importante na sinalização celular relacionada a diferenciação osteogênica (Fig. 23):

1. A ligação de BMP2 ao receptor ativa sua cascata de fosforilação principal, mas também pode ativar a NOX4 e uma quinase capaz de fosforilar (e inativar) Prx. Dessa forma, a NOX produziria peróxido de hidrogênio, que poderia reagir com moléculas-alvo (como uma fosfatase, por exemplo) sem ser reduzido pela Prx. Se essa hipótese for válida, a oxidação (e inativação) de uma fosfatase, ou a oxidação (e ativação) de uma quinase, poderia levar ao aumento do sinal de fosforilação disparado por BMP2.

2. A ligação da BMP2 ao receptor pode ativar sua cascata de fosforilação principal, mas também ativa a NOX4, que produz peróxido de hidrogênio em elevadas concentrações, em determinados subcompartimentos celulares, capaz de inativar a Prx por superoxidação. Dessa forma, o restante do peróxido de 
hidrogênio poderia reagir com outras moléculas-alvo e os efeitos seriam semelhantes ao descrito no item acima.

3. Além disso, outras hipóteses poderiam explicar a participação do peróxido de hidrogênio e das Prxs nessa via. A oxidação de Prx poderia servir como um sensor do aumento da atividade da NOX4, e essa Prx poderia transferir equivalentes oxidantes para outras proteínas-alvo, através de interação física. Por último, a oxidação de Prx induz a oxidação das proteínas Trx, que reduzem as Prxs e ficam oxidadas. Dessa forma, o pool de Trx reduzida também seria menor dentro da célula, permitindo que as proteínas que foram oxidadas, não sejam reduzidas. Esses modelos de sinalização baseados em Prx e Trx estão revisados em Netto e Antunes (2016).

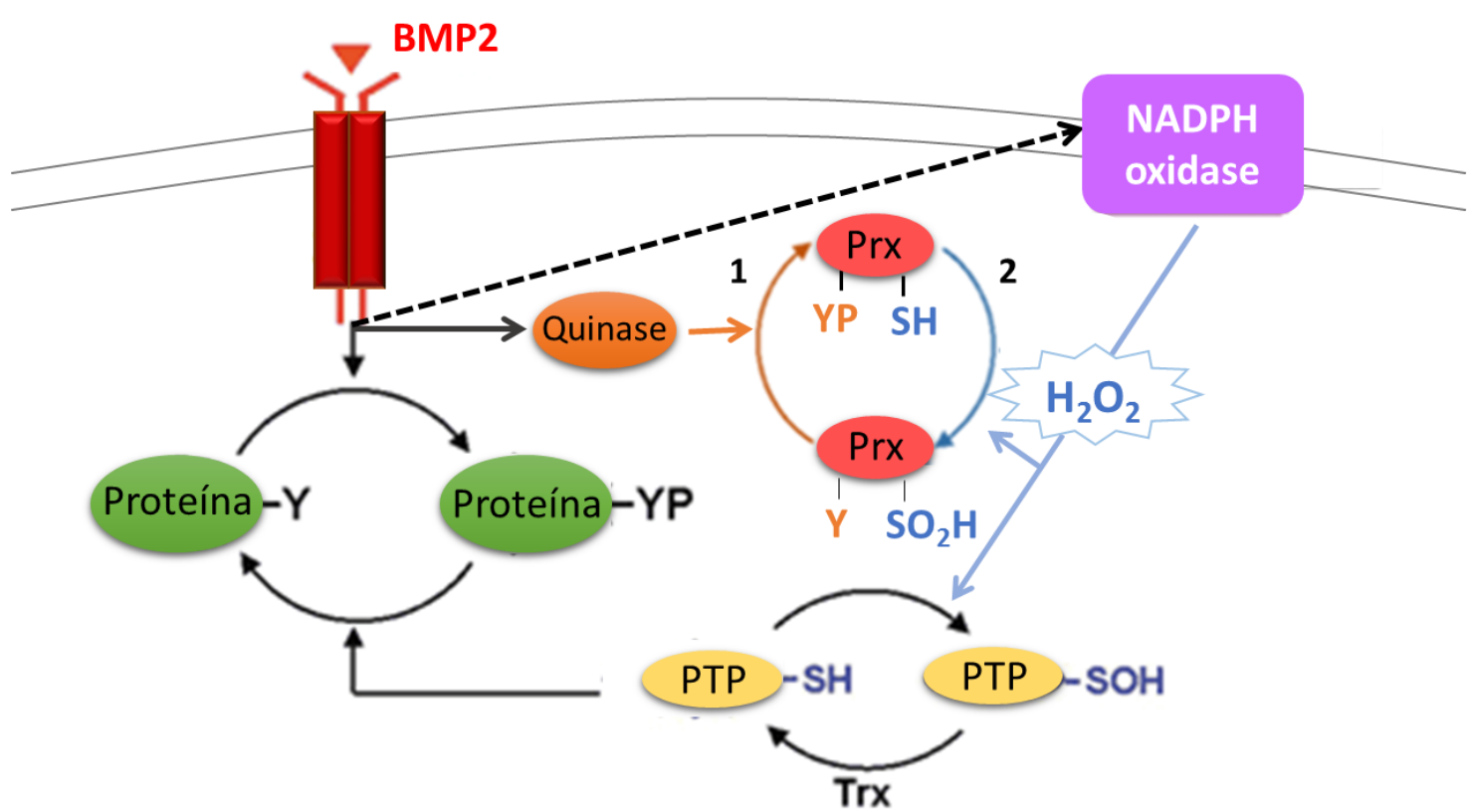

Figura 23. Possíveis modelos para a participação de oxidantes na diferenciação osteogênica. A ligação de BMP2 ao seu receptor ativa a via de sinalização canônica de BMP, mas pode também ativar a produção de peróxido de hidrogênio pela NOX4 e outras vias secundárias, para garantir o aumento do sinal disparado. O peróxido de hidrogênio produzido pode inativar Prxs por superoxidação e oxidar outros alvos, como fosfatases, no exemplo. 
Os resultados desse trabalho não nos permite sugerir qual seria o mecanismo de atuação mais relevante neste modelo. Entretanto, os resultados aqui apresentados, juntamente com a análise de dados da literatura, indicam que processos redox podem ser subjacentes a vias de diferenciação osteogênica. Além disso, apresentamos evidências de que Prx1 e peróxido de hidrogênio estão envolvidos no processo de diferenciação aqui analisado.

O modelo utilizado nesta dissertação para indução da diferenciação com BMP2 também nos traz vantagens, quando analisamos a literatura na área. Além dos dados de diferenciação osteogênica disponíveis, outros trabalhos abordam vias de calcificação vascular induzidas por BMP2 e/ou por estresse oxidativo. A indução da calcificação de células musculares lisas é uma característica da condição de aterosclerose. Nestes casos, o aumento no conteúdo de ROS intracelulares pode induzir a expressão de BMP2 e Runx2, que vão disparar a sinalização responsável pela alteração do fenótipo celular (Johnson, Leopold e Loscalzo, 2006). Outros trabalhos mostram que o estímulo com BMP2 leva ao aumento na geração intracelular de ROS, que direcionam a calcificação (Liberman et al., 2011). Esses dados mostram que deve existir uma relação íntima entre a via de sinalização de BMP2 e as ROS, que também pode atuar na diferenciação osteogênica.

Além disso, outros trabalhos mostram que o peróxido de hidrogênio pode ativar a quinase Akt que, por sua vez, ativa a transcrição de Runx2 e direciona a alteração de fenótipo de células musculares contráteis para uma característica osteogênica (Byon et al., 2008). Além de sofrer modulação redox em vias relacionadas a diferenciação osteogênica ou calcificação de células do tecido vascular, a Akt fosforila Osx e Dlx5 e 
aumenta a estabilidade, atividade osteogênica e transcricional dessas duas proteínas (Choi et al., 2011; Jeong et al., 2011).

Além disso, diferentes modelos celulares possuem respostas às ROS relacionadas à via de PI3K/AKT. Ela é necessária para o processo de diferenciação adipogênica (Peng et al., 2003) e um efetor downstream dessa via, mTORC1, é responsável pela sinalização que leva ao aumento no metabolismo mitocondrial e geração de ROS essenciais para o processo de diferenciação de MSC em adipócitos (Tormos et al., 2011). Liao et al. (2013), utilizando células precursoras derivadas da pele, mostraram que a inibição de PI3K/AKT resulta em senescência e a inibição de PTEN promove a proliferação e atenua a senescência, sem, contudo, favorecer a diferenciação. Outros trabalhos demonstram a relação entre a produção endógena de ROS atuando sobre a via de PI3K/AKT e o processo de auto-renovação em células-tronco precursoras de espermatogônias (Lee et al., 2007), células progenitoras do cólon (Coant et al., 2010), células-tronco e progenitoras neurais (Yoneyama et al., 2010; Le Belle et al., 2011), células-tronco hematopoiéticas (Juntilla et al., 2010).

Além de Akt, outras proteínas também seriam possíveis alvos de regulação redox na diferenciação osteogênica: os fatores de transcrição AP-1 e ATF4. Membros da família AP-1 regulam a diferenciação de osteoblastos e cada um desses membros possuem diferentes efetores no processo (Long, 2012). Alguns membros da família AP-1 podem sofrer modulação redox ou participar da sinalização redox de maneira indireta, através da mediação por Trx e Ref-1 (Meyer, Pahl e Baeuerle, 1994; Karimpour et al., 2002; Liu et al., 2005). 
Do ponto de vista da compreensão de mecanismos relacionados a diferenciação osteogênica e linhagens de osteoblastos, estudos como esses tem significância médica direta. Diversos problemas relacionados a doenças esqueléticas, principalmente com o envelhecimento, são acompanhados pela diminuição na produção e função de osteoblastos. Estratégias seguras e efetivas para estimular sua produção e atividade estão, dessa forma, sob grande demanda. Além disso, a compreensão de mecanismos redox subjacentes à diferenciação osteogênica também pode ser útil para auxiliar na prevenção de problemas vasculares e ósseos, associados a produção exacerbada de moléculas oxidantes, que podem também ser prejudiciais aos indivíduos. 


\section{Conclusões}

- Foi demonstrado que as células MC3T3-E1 respondem ao tratamento com BMP2 com aumento de fosforilação de Smad 1/5/8, aumento na expressão de Osteocalcina e aumento na deposição de matriz extracelular calcificada, de maneira dosedependente.

- Considerando as condições estabelecidas neste trabalho, o tratamento com antioxidantes (NAC e PEG-catalase) retardou ou impediu que as células diferenciassem.

- Por outro lado, o tratamento com peróxido de hidrogênio nas doses testadas, mesmo que seja danoso para a proliferação celular, não alterou o potencial de diferenciação osteogênico.

- O estímulo a diferenciação osteogênica levou ao aumento na expressão de NOX4, que pode estar associado ao aumento da concentração de peróxido de hidrogênio intracelular. Entretanto, nas condições testadas, não foi possível detectar o aumento na produção de peróxido de hidrogênio.

- A indução à diferenciação não causa aumento na expressão de PRX, no entanto, o tratamento com BMP2 está relacionado ao aumento na oxidação de Prx1. 


\section{Referências Bibliográficas}

AGUIRRE, J.; LAMBETH, J. D. Nox enzymes from fungus to fly to fish and what they tell us about Nox function in mammals. Free Radic Biol Med, v. 49, n. 9, p. 1342-53, 2010

ALDIERI, E. et al. Classical inhibitors of NOX NAD(P)H oxidases are not specific. Curr Drug Metab, v. 9, n. 8, p. $686-96,2008$

APEL, K.; HIRT, H. Reactive oxygen species: metabolism, oxidative stress, and signal transduction. Annu Rev Plant Biol, v. 55, p. 373-99, 2004.

ARAI, M. et al. Effects of reactive oxygen species (ROS) on antioxidant system and osteoblastic differentiation in MC3T3-E1 cells. IUBMB Life, v. 59, n. 1, p. 27-33, 2007.

ARBISER, J. L. et al. Reactive oxygen generated by Nox1 triggers the angiogenic switch. Proc Natl Acad Sci U S A, v. 99, n. 2, p. 715-20, 2002.

ARMSTRONG, L. et al. Human induced pluripotent stem cell lines show stress defense mechanisms and mitochondrial regulation similar to those of human embryonic stem cells. Stem Cells, v. 28, n. 4, p. 661-73,2010.

ATEGHANG, B. et al. Regulation of cardiotrophin-1 expression in mouse embryonic stem cells by HIF-1alpha and intracellular reactive oxygen species. J Cell Sci, v. 119, n. Pt 6, p. 1043-52, 2006.

BABIOR, B. M. The NADPH oxidase of endothelial cells. IUBMB Life, v. 50, n. 4-5, p. 267-9, 2000.

BAFFI, M. O.; MORAN, M. A.; SERRA, R. Tgfbr2 regulates the maintenance of boundaries in the axial skeleton. Dev Biol, v. 296, n. 2, p. 363-74, 2006.

BEDARD, K.; KRAUSE, K. H. The NOX family of ROS-generating NADPH oxidases: physiology and pathophysiology. Physiol Rev, v. 87, n. 1, p. 245-313, 2007.

BELOUSOV, V. V. et al. Genetically encoded fluorescent indicator for intracellular hydrogen peroxide. Nat Methods, v. 3, n. 4, p. 281-6, 2006.

BERNDT, C.; LILLIG, C. H.; HOLMGREN, A. Thiol-based mechanisms of the thioredoxin and glutaredoxin systems: implications for diseases in the cardiovascular system. Am J Physiol Heart Circ Physiol, v. 292, n. 3, p. H1227-36, 2007.

BITEAU, B.; LABARRE, J.; TOLEDANO, M. B. ATP-dependent reduction of cysteine-sulphinic acid by S. cerevisiae sulphiredoxin. Nature, v. 425, n. 6961, p. 980-4, 2003. 
BOVERIS, A.; CADENAS, E. Mitochondrial production of superoxide anions and its relationship to the antimycin insensitive respiration. FEBS Lett, v. 54, n. 3, p. 311-4, 1975.

BROWN, D. I.; GRIENDLING, K. K. Nox proteins in signal transduction. Free Radic Biol Med, v. 47, n. 9, p. 1239-53, 2009.

BRYK, R.; GRIFFIN, P.; NATHAN, C. Peroxynitrite reductase activity of bacterial peroxiredoxins. Nature, v. 407, n. 6801, p. 211-5, 2000.

BUCKLEY, S. M. et al. Regulation of pluripotency and cellular reprogramming by the ubiquitinproteasome system. Cell Stem Cell, v. 11, n. 6, p. 783-98, 2012.

BUGGISCH, M. et al. Stimulation of ES-cell-derived cardiomyogenesis and neonatal cardiac cell proliferation by reactive oxygen species and NADPH oxidase. J Cell Sci, v. 120, n. Pt 5, p. 885-94, 2007.

BUSTIN, S. A. et al. The MIQE guidelines: minimum information for publication of quantitative real-time PCR experiments. Clin Chem, v. 55, n. 4, p. 611-22, 2009.

BYON, C. H. et al. Oxidative stress induces vascular calcification through modulation of the osteogenic transcription factor Runx2 by AKT signaling. J Biol Chem, v. 283, n. 22, p. 15319-27, 2008.

CAO, J. et al. Prdx1 inhibits tumorigenesis via regulating PTEN/AKT activity. EMBO J, v. 28, n. 10, p. 1505-17, 2009

CHAE, H. Z.; CHUNG, S. J.; RHEE, S. G. Thioredoxin-dependent peroxide reductase from yeast. J Biol Chem, v. 269, n. 44, p. 27670-8, 1994.

$\mathrm{CHAE}, \mathrm{H}$. Z. et al. Characterization of three isoforms of mammalian peroxiredoxin that reduce peroxides in the presence of thioredoxin. Diabetes Res Clin Pract, v. 45, n. 2-3, p. 101-12, 1999.

CHAUDHARI, P.; YE, Z.; JANG, Y. Y. Roles of Reactive Oxygen Species in the Fate of Stem Cells. Antioxid Redox Signal, 2012.

CHEN, C. T. et al. Coordinated changes of mitochondrial biogenesis and antioxidant enzymes during osteogenic differentiation of human mesenchymal stem cells. Stem Cells, v. 26, n. 4, p. $960-8,2008$.

CHEN, D.; ZHAO, M.; MUNDY, G. R. Bone morphogenetic proteins. Growth Factors, v. 22, n. 4, p. 233-41, 2004.

CHEN, G.; DENG, C.; LI, Y. P. TGF- $\beta$ and BMP signaling in osteoblast differentiation and bone formation. Int J Biol Sci, v. 8, n. 2, p. 272-88, 2012. 
CHEN, Z. X.; PERVAIZ, S. Bcl-2 induces pro-oxidant state by engaging mitochondrial respiration in tumor cells. Cell Death Differ, v. 14, n. 9, p. 1617-27, 2007.

CHENG, G. et al. Homologs of gp91phox: cloning and tissue expression of Nox3, Nox4, and Nox5. Gene, v. 269, n. 1-2, p. 131-40, 2001.

$\mathrm{CHO}, \mathrm{Y} . \mathrm{M}$. et al. Dynamic changes in mitochondrial biogenesis and antioxidant enzymes during the spontaneous differentiation of human embryonic stem cells. Biochem Biophys Res Commun, v. 348, n. 4, p. 1472-8, 2006.

$\mathrm{CHOI}, \mathrm{M}$. $\mathrm{H}$. et al. Regulation of PDGF signalling and vascular remodelling by peroxiredoxin II. Nature, v. 435, n. 7040, p. 347-53, 2005.

$\mathrm{CHOI}, \mathrm{Y}$. H. et al. Akt phosphorylates and regulates the osteogenic activity of Osterix. Biochem Biophys Res Commun, v. 411, n. 3, p. 637-41, 2011.

CHUNG, C. Y. et al. Serial passage of MC3T3-E1 cells alters osteoblastic function and responsiveness to transforming growth factor-beta1 and bone morphogenetic protein-2. Biochem Biophys Res Commun, v. 265, n. 1, p. 246-51, 1999.

CHUNG, $\mathrm{S}$. et al. Mitochondrial oxidative metabolism is required for the cardiac differentiation of stem cells. Nat Clin Pract Cardiovasc Med, v. 4 Suppl 1, p. S60-7, 2007.

COANT, N. et al. NADPH oxidase 1 modulates WNT and NOTCH1 signaling to control the fate of proliferative progenitor cells in the colon. Mol Cell Biol, v. 30, n. 11, p. 2636-50, 2010.

CONRAD, M. et al. 12/15-lipoxygenase-derived lipid peroxides control receptor tyrosine kinase signaling through oxidation of protein tyrosine phosphatases. Proc Natl Acad Sci U S A, v. 107, n. 36, p. 15774-9, 2010.

COX, A. G.; WINTERBOURN, C. C.; HAMPTON, M. B. Mitochondrial peroxiredoxin involvement in antioxidant defence and redox signalling. Biochem J, v. 425, n. 2, p. 313-25, 2010.

D'AUTRÉAUX, B.; TOLEDANO, M. B. ROS as signalling molecules: mechanisms that generate specificity in ROS homeostasis. Nat Rev Mol Cell Biol, v. 8, n. 10, p. 813-24, 2007.

DAY, A. M. et al. Inactivation of a peroxiredoxin by hydrogen peroxide is critical for thioredoxinmediated repair of oxidized proteins and cell survival. Mol Cell, v. 45, n. 3, p. 398-408, 2012.

DELAUNAY, A. et al. A thiol peroxidase is an $\mathrm{H} 2 \mathrm{O} 2$ receptor and redox-transducer in gene activation. Cell, v. 111, n. 4, p. 471-81, 2002. 
DEMASI, M.; SIMÕES, V.; BONATTO, D. Cross-talk between redox regulation and the ubiquitinproteasome system in mammalian cell differentiation. Biochim Biophys Acta, v. 1850, n. 8, p. 1594-606, 2015.

DERYNCK, R.; AKHURST, R. J. Differentiation plasticity regulated by TGF-beta family proteins in development and disease. Nat Cell Biol, v. 9, n. 9, p. 1000-4, 2007.

DERYNCK, R.; ZHANG, Y. E. Smad-dependent and Smad-independent pathways in TGF-beta family signalling. Nature, v. 425, n. 6958, p. 577-84, 2003.

FINKEL, T. Signal transduction by reactive oxygen species. J Cell Biol, v. 194, n. 1, p. 7-15, 2011.

FOLMES, C. D. et al. Somatic oxidative bioenergetics transitions into pluripotency-dependent glycolysis to facilitate nuclear reprogramming. Cell Metab, v. 14, n. 2, p. 264-71, 2011.

FORMAN, H. J. et al. Even free radicals should follow some rules: a guide to free radical research terminology and methodology. Free Radic Biol Med, v. 78, p. 233-5, 2015.

FORMAN, H. J.; TRABER, M.; URSINI, F. Antioxidants: GRABbing new headlines. Free Radic Biol Med, v. 66, p. 1-2, 2014.

FOSTER, D. B. et al. Redox signaling and protein phosphorylation in mitochondria: progress and prospects. J Bioenerg Biomembr, v. 41, n. 2, p. 159-68, 2009.

FOURQUET, S. et al. The dual functions of thiol-based peroxidases in $\mathrm{H} 2 \mathrm{O} 2$ scavenging and signaling. Antioxid Redox Signal, v. 10, n. 9, p. 1565-76, 2008.

FRIDOVICH, I. Superoxide dismutases. Annu Rev Biochem, v. 44, p. 147-59, 1975.

FRIEDMAN, M. S.; LONG, M. W.; HANKENSON, K. D. Osteogenic differentiation of human mesenchymal stem cells is regulated by bone morphogenetic protein-6. J Cell Biochem, v. 98, $n$. 3, p. 538-54, 2006.

FUCHS, E.; CHEN, T. A matter of life and death: self-renewal in stem cells. EMBO Rep, v. 14, n. 1, p. 39-48, 2013.

GIANNONI, E. et al. Intracellular reactive oxygen species activate Src tyrosine kinase during cell adhesion and anchorage-dependent cell growth. Mol Cell Biol, v. 25, n. 15, p. 6391-403, 2005.

HALL, A. et al. Structure-based insights into the catalytic power and conformational dexterity of peroxiredoxins. Antioxid Redox Signal, v. 15, n. 3, p. 795-815, 2011. 
HAMANAKA, R. B. et al. Mitochondrial reactive oxygen species promote epidermal differentiation and hair follicle development. Sci Signal, v. 6, n. 261, p. ra8, 2013.

HAYASHI, T.; UENO, Y.; OKAMOTO, T. Oxidoreductive regulation of nuclear factor kappa B. Involvement of a cellular reducing catalyst thioredoxin. J Biol Chem, v. 268, n. 15, p. 11380-8, 1993.

HE, S.; NAKADA, D.; MORRISON, S. J. Mechanisms of stem cell self-renewal. Annu Rev Cell Dev Biol, v. 25, p. 377-406, 2009.

HELDIN, C. H.; MIYAZONO, K.; TEN DIJKE, P. TGF-beta signalling from cell membrane to nucleus through SMAD proteins. Nature, v. 390, n. 6659, p. 465-71, 1997.

HERPIN, A.; CUNNINGHAM, C. Cross-talk between the bone morphogenetic protein pathway and other major signaling pathways results in tightly regulated cell-specific outcomes. FEBS J, v. 274, n. 12, p. 2977-85, 2007.

HOFMANN, B.; HECHT, H. J.; FLOHÉ, L. Peroxiredoxins. Biol Chem, v. 383, n. 3-4, p. 347-64, 2002.

HOLMSTRÖM, K. M.; FINKEL, T. Cellular mechanisms and physiological consequences of redoxdependent signalling. Nat Rev Mol Cell Biol, v. 15, n. 6, p. 411-21, 2014.

ITO, K. et al. Regulation of oxidative stress by ATM is required for self-renewal of haematopoietic stem cells. Nature, v. 431, n. 7011, p. 997-1002, 2004.

ITO, K.; SUDA, T. Metabolic requirements for the maintenance of self-renewing stem cells. Nat Rev Mol Cell Biol, v. 15, n. 4, p. 243-56, 2014.

IWAI, K.; NAGANUMA, A.; KUGE, S. Peroxiredoxin Ahp1 acts as a receptor for alkylhydroperoxides to induce disulfide bond formation in the Cad1 transcription factor. J Biol Chem, v. 285, n. 14, p. 10597-604, 2010.

JAISWAL, R. K. et al. Adult human mesenchymal stem cell differentiation to the osteogenic or adipogenic lineage is regulated by mitogen-activated protein kinase. J Biol Chem, v. 275, n. 13, p. 9645-52, 2000.

JANG, Y. Y.; SHARKIS, S. J. A low level of reactive oxygen species selects for primitive hematopoietic stem cells that may reside in the low-oxygenic niche. Blood, v. 110, n. 8, p. 305663, 2007.

JEONG, H. M. et al. Akt phosphorylates and regulates the function of Dlx5. Biochem Biophys Res Commun, v. 409, n. 4, p. 681-6, 2011. 
JOHNSON, R. C.; LEOPOLD, J. A.; LOSCALZO, J. Vascular calcification: pathobiological mechanisms and clinical implications. Circ Res, v. 99, n. 10, p. 1044-59, 2006.

JUNTILLA, M. M. et al. AKT1 and AKT2 maintain hematopoietic stem cell function by regulating reactive oxygen species. Blood, v. 115, n. 20, p. 4030-8, 2010.

KANZAKI, S. et al. Dual effects of heparin on BMP-2-induced osteogenic activity in MC3T3-E1 cells. Pharmacol Rep, v. 63, n. 5, p. 1222-30, 2011.

KARIMPOUR, S. et al. Thioredoxin reductase regulates AP-1 activity as well as thioredoxin nuclear localization via active cysteines in response to ionizing radiation. Oncogene, v. 21, n. 41, p. 6317-27, 2002.

KARPLUS, P. A. A primer on peroxiredoxin biochemistry. Free Radic Biol Med, v. 80, p. 183-90, 2015.

$\mathrm{KIM}, \mathrm{K}$. et al. The isolation and purification of a specific "protector" protein which inhibits enzyme inactivation by a thiol/Fe(III)/O2 mixed-function oxidation system. J Biol Chem, v. 263, n. 10, p. 4704-11,1988.

KIM, S. U. et al. Dominant role of peroxiredoxin/JNK axis in stemness regulation during neurogenesis from embryonic stem cells. Stem Cells, v. 32, n. 4, p. 998-1011, 2014.

$\mathrm{KIM}, \mathrm{Y}$. J. et al. Prx1 suppresses radiation-induced c-Jun NH2-terminal kinase signaling in lung cancer cells through interaction with the glutathione S-transferase $\mathrm{Pi} / \mathrm{c}$-Jun $\mathrm{NH}$-terminal kinase complex. Cancer Res, v. 66, n. 14, p. 7136-42, 2006.

KOBAYASHI, C. I.; SUDA, T. Regulation of reactive oxygen species in stem cells and cancer stem cells. J Cell Physiol, v. 227, n. 2, p. 421-30, 2012.

LANGENBACH, F.; HANDSCHEL, J. Effects of dexamethasone, ascorbic acid and $\beta$ glycerophosphate on the osteogenic differentiation of stem cells in vitro. Stem Cell Res Ther, v. 4, n. 5, p. 117, 2013.

LE BELLE, J. E. et al. Proliferative neural stem cells have high endogenous ROS levels that regulate self-renewal and neurogenesis in a PI3K/Akt-dependant manner. Cell Stem Cell, v. 8, n. 1, p. 5971, 2011.

LEE, J. et al. Akt mediates self-renewal division of mouse spermatogonial stem cells. Development, v. 134, n. 10, p. 1853-9, 2007.

LEE, N. K. et al. A crucial role for reactive oxygen species in RANKL-induced osteoclast differentiation. Blood, v. 106, n. 3, p. 852-9, 2005. 
LEE, S. R. et al. Reversible inactivation of protein-tyrosine phosphatase $1 B$ in A431 cells stimulated with epidermal growth factor. J Biol Chem, v. 273, n. 25, p. 15366-72, 1998.

LIAN, J. B. et al. Networks and hubs for the transcriptional control of osteoblastogenesis. Rev Endocr Metab Disord, v. 7, n. 1-2, p. 1-16, 2006.

. Transcriptional control of osteoblast differentiation. Biochem Soc Trans, v. 26, n. 1, p. 14-21, 1998.

MicroRNA control of bone formation and homeostasis. Nat Rev Endocrinol, v. 8, n. 4, p. 212-27, 2012.

LIAO, J. et al. Inhibition of PTEN Tumor Suppressor Promotes the Generation of Induced Pluripotent Stem Cells. Mol Ther, v. 21, p. 1242-1250, 2013.

LIBERMAN, M. et al. Bone morphogenetic protein-2 activates NADPH oxidase to increase endoplasmic reticulum stress and human coronary artery smooth muscle cell calcification. Biochem Biophys Res Commun, v. 413, n. 3, p. 436-41, 2011.

LIU, H. et al. Redox-dependent transcriptional regulation. Circ Res, v. 97, n. 10, p. 967-74, 2005.

LIVAK, K.J. e SCHMITTGEN, T.D. Analysis of relative gene expression data using real-time quantitative PCR and the 2(-Delta Delta C(T)) Method. Methods, v. 25, n. 4, p. 402-8, 2001.

LONG, F. Building strong bones: molecular regulation of the osteoblast lineage. Nat Rev Mol Cell Biol, v. 13, n. 1, p. 27-38, 2012.

LU, R. et al. Systems-level dynamic analyses of fate change in murine embryonic stem cells. Nature, v. 462, n. 7271, p. 358-62, 2009.

LUKYANOV, K. A.; BELOUSOV, V. V. Genetically encoded fluorescent redox sensors. Biochim Biophys Acta, v. 1840, n. 2, p. 745-56, 2014.

LUPPEN, C. A. et al. BMP-2 vs. BMP-4 expression and activity in glucocorticoid-arrested MC3T3E1 osteoblasts: Smad signaling, not alkaline phosphatase activity, predicts rescue of mineralization. Growth Factors, v. 26, n. 4, p. 226-37, 2008.

Bone morphogenetic protein-2 restores mineralization in glucocorticoid-inhibited MC3T3-E1 osteoblast cultures. J Bone Miner Res, v. 18, n. 7, p. 1186-97, 2013.

LUU, H. H. et al. Distinct roles of bone morphogenetic proteins in osteogenic differentiation of mesenchymal stem cells. J Orthop Res, v. 25, n. 5, p. 665-77, 2007.

MANDAL, C. C. et al. Reactive oxygen species derived from Nox4 mediate BMP2 gene transcription and osteoblast differentiation. Biochem J, v. 433, n. 2, p. 393-402, 2011. 
MATSUNOBU, T. et al. Critical roles of the TGF-beta type I receptor ALK5 in perichondrial formation and function, cartilage integrity, and osteoblast differentiation during growth plate development. Dev Biol, v. 332, n. 2, p. 325-38, 2009.

MATTHEWS, J. R. et al. Thioredoxin regulates the DNA binding activity of NF-kappa B by reduction of a disulphide bond involving cysteine 62. Nucleic Acids Res, v. 20, n. 15, p. 3821-30, 1992.

MEISSNER, A. Epigenetic modifications in pluripotent and differentiated cells. Nat Biotechnol, v. 28, n. 10, p. 1079-88, 2010.

MEYER, M.; PAHL, H. L.; BAEUERLE, P. A. Regulation of the transcription factors NF-kappa B and AP-1 by redox changes. Chem Biol Interact, v. 91, n. 2-3, p. 91-100, 1994.

MIKAMI, Y. et al. Inductive effects of dexamethasone on the mineralization and the osteoblastic gene expressions in mature osteoblast-like ROS17/2.8 cells. Biochem Biophys Res Commun, v. 362, n. 2, p. 368-73, 2007.

NETTO, L. E. et al. Removal of hydrogen peroxide by thiol-specific antioxidant enzyme (TSA) is involved with its antioxidant properties. TSA possesses thiol peroxidase activity. J Biol Chem, $\mathrm{v}$. 271, n. 26, p. 15315-21, 1996.

NETTO, L. E.; ANTUNES, F. The Roles of Peroxiredoxin and Thioredoxin in Hydrogen Peroxide Sensing and in Signal Transduction. Mol Cells, 2016.

NETTO, L. E. et al. Conferring specificity in redox pathways by enzymatic thiol/disulfide exchange reactions. Free Radic Res, p. 1-40, 2016.

OGASAWARA, T. et al. Bone morphogenetic protein 2-induced osteoblast differentiation requires Smad-mediated down-regulation of Cdk6. Mol Cell Biol, v. 24, n. 15, p. 6560-8, 2004.

OSTMAN, A. et al. Regulation of protein tyrosine phosphatases by reversible oxidation. J Biochem, v. 150, n. 4, p. 345-56, 2011.

PAPADIA, S. et al. Synaptic NMDA receptor activity boosts intrinsic antioxidant defenses. Nat Neurosci, v. 11, n. 4, p. 476-87, 2008.

PATTAPPA, G. et al. The metabolism of human mesenchymal stem cells during proliferation and differentiation. J Cell Physiol, v. 226, n. 10, p. 2562-70, 2011.

Continuous and uninterrupted oxygen tension influences the colony formation and oxidative metabolism of human mesenchymal stem cells. Tissue Eng Part C Methods, v. 19, n. 1, p. 68-79, 2013. 
PENG, X. D. et al. Dwarfism, impaired skin development, skeletal muscle atrophy, delayed bone development, and impeded adipogenesis in mice lacking Akt1 and Akt2. Genes Dev, v. 17, n. 11, p. 1352-65, 2003.

PERVAIZ, S.; TANEJA, R.; GHAFFARI, S. Oxidative stress regulation of stem and progenitor cells. Antioxid Redox Signal, v. 11, n. 11, p. 2777-89, 2009.

PESHENKO, I. V.; SHICHI, H. Oxidation of active center cysteine of bovine 1-Cys peroxiredoxin to the cysteine sulfenic acid form by peroxide and peroxynitrite. Free Radic Biol Med, v. 31, n. 3, p. 292-303, 2001.

PESKIN, A. V. et al. Hyperoxidation of peroxiredoxins 2 and 3: rate constants for the reactions of the sulfenic acid of the peroxidatic cysteine. J Biol Chem, v. 288, n. 20, p. 14170-7, 2013.

PITTENGER, M. F. et al. Multilineage potential of adult human mesenchymal stem cells. Science, v. 284, n. 5411, p. 143-7, 1999.

PRIGIONE, A. et al. The senescence-related mitochondrial/oxidative stress pathway is repressed in human induced pluripotent stem cells. Stem Cells, v. 28, n. 4, p. 721-33, 2010.

QUARLES, L. D. et al. Distinct proliferative and differentiated stages of murine MC3T3-E1 cells in culture: an in vitro model of osteoblast development. J Bone Miner Res, v. 7, n. 6, p. 683-92, 1992.

RAY, P. D.; HUANG, B. W.; TSUII, Y. Reactive oxygen species (ROS) homeostasis and redox regulation in cellular signaling. Cell Signal, v. 24, n. 5, p. 981-90, 2012.

REN, $F$. et al. New insights into redox regulation of stem cell self-renewal and differentiation. Biochim Biophys Acta, v. 1850, n. 8, p. 1518-26, 2015.

RHEE, S. G. et al. Hydrogen peroxide: a key messenger that modulates protein phosphorylation through cysteine oxidation. Sci STKE, v. 2000, n. 53, p. pe1, 2000.

RHEE, S. G.; CHAE, H. Z.; KIM, K. Peroxiredoxins: a historical overview and speculative preview of novel mechanisms and emerging concepts in cell signaling. Free Radic Biol Med, v. 38, n. 12, p. 1543-52, 2005.

RHEE, S. G. et al. Peroxiredoxin functions as a peroxidase and a regulator and sensor of local peroxides. J Biol Chem, v. 287, n. 7, p. 4403-10, 2012.

ROBINSON, J. M. Phagocytic leukocytes and reactive oxygen species. Histochem Cell Biol, v. 131, n. 4, p. 465-9, 2009. 
ROOS, G.; MESSENS, J. Protein sulfenic acid formation: from cellular damage to redox regulation. Free Radic Biol Med, v. 51, n. 2, p. 314-26, 2011.

SAITOH, M. et al. Mammalian thioredoxin is a direct inhibitor of apoptosis signal-regulating kinase (ASK) 1. EMBO J, v. 17, n. 9, p. 2596-606, 1998.

SALIM, A. et al. Transient changes in oxygen tension inhibit osteogenic differentiation and Runx2 expression in osteoblasts. J Biol Chem. v. 279, n. 38, p :40007-16, 2004.

SARETZKI, G. et al. Downregulation of multiple stress defense mechanisms during differentiation of human embryonic stem cells. Stem Cells, v. 26, n. 2, p. 455-64, 2008.

SATTLER, M. et al. Hematopoietic growth factors signal through the formation of reactive oxygen species. Blood, v. 93, n. 9, p. 2928-35, 1999.

SEO, J. H. et al. Novel protective mechanism against irreversible hyperoxidation of peroxiredoxin: Nalpha-terminal acetylation of human peroxiredoxin II. J Biol Chem, v. 284, n. 20, p. 13455-65, 2009.

SHARIFPANAH, F. et al. Peroxisome proliferator-activated receptor alpha agonists enhance cardiomyogenesis of mouse ES cells by utilization of a reactive oxygen species-dependent mechanism. Stem Cells, v. 26, n. 1, p. 64-71, 2008.

SMITH, J. et al. Redox state is a central modulator of the balance between self-renewal and differentiation in a dividing glial precursor cell. Proc Natl Acad Sci U S A, v. 97, n. 18, p. 10032$7,2000$.

STEIN, G. S.; LIAN, J. B. Molecular mechanisms mediating proliferation/differentiation interrelationships during progressive development of the osteoblast phenotype. Endocr Rev, v. 14, n. 4, p. 424-42, 1993.

STRIKOUDIS, A.; GUILLAMOT, M.; AIFANTIS, I. Regulation of stem cell function by protein ubiquitylation. EMBO Rep, v. 15, n. 4, p. 365-82, 2014.

SUNDARESAN, M. et al. Requirement for generation of $\mathrm{H} 2 \mathrm{O} 2$ for platelet-derived growth factor signal transduction. Science, v. 270, n. 5234, p. 296-9, 1995.

TAIRUM, C. A. et al. Disulfide biochemistry in 2-cys peroxiredoxin: requirement of Glu50 and Arg146 for the reduction of yeast Tsa1 by thioredoxin. J Mol Biol, v. 424, n. 1-2, p. 28-41, 2012.

TONKS, N. K. Redox redux: revisiting PTPs and the control of cell signaling. Cell, v. 121, n. 5, p. 667-70, 2005. 
TORII, Y.; HITOMI, K.; TSUKAGOSHI, N. Synergistic effect of BMP-2 and ascorbate on the phenotypic expression of osteoblastic MC3T3-E1 cells. Mol Cell Biochem, v. 165, n. 1, p. 25-9, 1996.

TORMOS, K. V. et al. Mitochondrial complex III ROS regulate adipocyte differentiation. Cell Metab, v. 14, n. 4, p. 537-44, 2011.

VAN DER VLIET, A. NADPH oxidases in lung biology and pathology: host defense enzymes, and more. Free Radic Biol Med, v. 44, n. 6, p. 938-55, 2008.

VEAL, E.; DAY, A. Hydrogen peroxide as a signaling molecule. Antioxid Redox Signal, v. 15, n. 1, p. 147-51, 2011.

VIGNAIS, P. V. The superoxide-generating NADPH oxidase: structural aspects and activation mechanism. Cell Mol Life Sci, v. 59, n. 9, p. 1428-59, 2002.

WANG, D. et al. Isolation and characterization of MC3T3-E1 preosteoblast subclones with distinct in vitro and in vivo differentiation/mineralization potential. J Bone Miner Res, v. 14, n. 6, p. 893-903, 1999.

WANG, J. et al. Dependence of mouse embryonic stem cells on threonine catabolism. Science, v. 325, n. 5939, p. 435-9, 2009.

WANG, K. et al. Redox homeostasis: the linchpin in stem cell self-renewal and differentiation. Cell Death Dis, v. 4, p. e537, 2013.

WANG, N. et al. Suppressing phosphatidylcholine-specific phospholipase $C$ and elevating ROS level, NADPH oxidase activity and Rb level induced neuronal differentiation in mesenchymal stem cells. J Cell Biochem, v. 100, n. 6, p. 1548-57, 2007.

WARBURG, O. Über die Oxydationen in lebenden Zellen nach Versuchen am Seeigelei, HoppeSeyler's Z. Physiol. Chem, 66 p. 305-340, 1910.

WEI, Q. et al. Sulfiredoxin-Peroxiredoxin IV axis promotes human lung cancer progression through modulation of specific phosphokinase signaling. Proc Natl Acad Sci U S A, v. 108, n. 17, p. 7004-9, 2011.

WEN, S. T.; VAN ETTEN, R. A. The PAG gene product, a stress-induced protein with antioxidant properties, is an Abl SH3-binding protein and a physiological inhibitor of c-Abl tyrosine kinase activity. Genes Dev, v. 11, n. 19, p. 2456-67, 1997.

WIND, S. et al. Comparative pharmacology of chemically distinct NADPH oxidase inhibitors. Br J Pharmacol, v. 161, n. 4, p. 885-98, 2010. 
WINTERBOURN, C. C. Reconciling the chemistry and biology of reactive oxygen species. Nat Chem Biol, v. 4, n. 5, p. 278-86, 2008.

The challenges of using fluorescent probes to detect and quantify specific reactive oxygen species in living cells. Biochim Biophys Acta, v. 1840, n. 2, p. 730-8, 2014.

WINTERBOURN, C. C.; HAMPTON, M. B. Thiol chemistry and specificity in redox signaling. Free Radic Biol Med, v. 45, n. 5, p. 549-61, 2008. 2015. . Redox biology: signaling via a peroxiredoxin sensor. Nat Chem Biol, v. 11, n. 1, p. 5-6,

WOO, H. A. et al. Inactivation of peroxiredoxin I by phosphorylation allows localized $\mathrm{H}(2) \mathrm{O}(2)$ accumulation for cell signaling. Cell, v. 140, n. 4, p. 517-28, 2010.

WOOD, Z. A.; POOLE, L. B.; KARPLUS, P. A. Peroxiredoxin evolution and the regulation of hydrogen peroxide signaling. Science, v. 300, n. 5619, p. 650-3, 2013.

WOOD, Z. A. et al. Structure, mechanism and regulation of peroxiredoxins. Trends Biochem Sci, v. 28, n. 1 , p. $32-40,2003$.

YAN, F. et al. Nox4 and redox signaling mediate TGF- $\beta$-induced endothelial cell apoptosis and phenotypic switch. Cell Death Dis, v. 5, p. e1010, 2014.

YAN, X. Z. et al. Effects of continuous passaging on mineralization of MC3T3-E1 cells with improved osteogenic culture protocol. Tissue Eng Part C Methods, v. 20, n. 3, p. 198-204, 2014.

YANES, O. et al. Metabolic oxidation regulates embryonic stem cell differentiation. Nat Chem Biol, v. 6, n. 6, p. 411-7, 2010.

YONEYAMA, M. et al. Endogenous reactive oxygen species are essential for proliferation of neural stem/progenitor cells. Neurochem Int, v. 56, n. 6-7, p. 740-6, 2010.

ZHANG, J. et al. UCP2 regulates energy metabolism and differentiation potential of human pluripotent stem cells. EMBO J, v. 30, n. 24, p. 4860-73, 2011.

. Metabolic regulation in pluripotent stem cells during reprogramming and self-renewal.

Cell Stem Cell, v. 11, n. 5, p. 589-95, 2012. 


\section{ANEXO I}

DEMASI, M.; SIMÕES, V.; BONATTO, D. Cross-talk between redox regulation and the ubiquitinproteasome system in mammalian cell differentiation. Biochim Biophys Acta, v. 1850, n. 8, p. 1594-606, 2015 
Review

\title{
Cross-talk between redox regulation and the ubiquitin-proteasome system in mammalian cell differentiation
}

\author{
Marilene Demasi $^{\mathrm{a}, *}$, Vanessa Simões ${ }^{\mathrm{b}}$, Diego Bonatto ${ }^{\mathrm{c}, * *}$ \\ a Laboratory of Biochemistry and Biophysics, Instituto Butantan, São Paulo, SP, Brazil \\ ${ }^{\mathrm{b}}$ Department of Genetics and Evolutive Biology, IB, Universidade de São Paulo, São Paulo, Brazil \\ c Center of Biotechnology, Universidade Federal do Rio Grande do Sul., Porto Alegre, RS, Brazil
}

\section{A R T I C L E I N F O}

\section{Article history:}

Received 25 August 2014

Received in revised form 24 October 2014

Accepted 28 October 2014

Available online 6 November 2014

\section{Keywords:}

Cell differentiation

Redox regulation

Proteasome

Systems biology

\begin{abstract}
A B S T R A C T
Background: Embryogenesis and stem cell differentiation are complex and orchestrated signaling processes. Reactive oxygen species (ROS) act as essential signal transducers in cellular differentiation, as has been shown through recent discoveries. On the other hand, the ubiquitin-proteasome system (UPS) has long been known to play an important role in all cellular regulated processes, including differentiation.

Scope of review: In the present review, we focus on findings that highlight the interplay between redox signaling and the UPS regarding cell differentiation. Through systems biology analyses, we highlight major routes during cardiomyocyte differentiation based on redox signaling and UPS modulation.

Major conclusion: Oxygen availability and redox signaling are fundamental regulators of cell fate upon differentiation. The UPS plays an important role in the maintenance of pluripotency and the triggering of differentiation. General significance: Cellular differentiation has been a matter of intense investigation mainly because of its potential therapeutic applications. Understanding regulatory mechanisms underlying cell differentiation is an important issue. Correspondingly, the role of UPS and regulation of redox processes have been emerged as essential factors to control the fate of cells upon differentiation. This article is part of a Special Issue entitled Redox regulation of differentiation and de-differentiation.
\end{abstract}

(c) 2014 Elsevier B.V. All rights reserved.

\section{Introduction}

Cellular differentiation is induced by gene expression changes triggered by finely tuned metabolic signals. Although growth factorspecific metabolic cascades that modulate gene expression are the classical signals for differentiation, the effect of $\mathrm{O}_{2}$ availability on stem cell function or during differentiation is a matter of intensive investigation, as depicted in the current literature [1-5]. Low oxygen levels during cell

Abbreviations: AGE, advanced glycation end products; AP1, Activator protein-1; BER, Base excision repair; CM, Cardiomyocytes; DEG, Differential expressed gene; ERAD, Endoplasmic Reticulum-Associated Degradation; ESC, embryonic stem cells; GSH, reduced glutathione; GSSG, oxidized glutathione; HIF, hypoxia-inducible factor; HSC, hematopoietic stem cells; MSC, mesenchymal stem cell; NER, nucleotide excision repair; NF-КB, nuclear factor-КB; PRDX, peroxiredoxin; ROS, reactive oxygen species; $\mathrm{SCF}^{\mathrm{Fbxw7}}$, SKP1-cullin-Fbox Fbxw7; SOD1, superoxide dismutase; TFAM, mitochondrial transcription factor A; TSC, tuberous sclerosis complex; UBL, ubiquitin-like proteins; UPR, unfolded protein response; UPS, ubiquitin-proteasome system

This article is part of a Special Issue entitled Redox regulation of differentiation and dedifferentiation.

* Correspondence to: M. Demasi, Laboratory of Biochemistry and Biophysics, Instituto Butantan, Av. Vital Brasil, 1500, Sao Paulo, SP 05502-001, Brazil.

** Co-Corresponding author.

E-mail addresses: marilene.demasi@butantan.gov.br (M. Demasi), diego@cbiot.ufrgs.br (D. Bonatto). differentiation were first described during mammalian embryogenesis [6]. More recently, studies with stem cells have firmly established that these cells reside into low oxygen ${ }^{1}$ niches and that their self-renewal ability is supported in this condition. However, stem cell differentiation also takes place in vitro at very high $\mathrm{O}_{2}$ concentrations (21\%). In fact, varying $\mathrm{O}_{2}$ levels induces diverse phenotypes during the differentiation of stem cells [7]. In conclusion, changes in $\mathrm{O}_{2}$ concentration do not trigger cell differentiation, though it is an important factor in determining the fate of cells upon differentiation. The hypoxic condition is regulated in cells and tissues by the hypoxia-inducible factor (HIF) [8]. Decreasing oxygen concentrations results in an exponential increase in HIF expression. In turn, HIF transactivates several genes whose products are involved in the metabolic adaptation to low oxygen availability (e.g., glucose transporters and glycolytic enzymes) and vascular (re) modeling to increase oxygen delivery (e.g., erythropoietin and the vascular endothelial growth factor). Other transcriptional factors that sense the $\mathrm{O}_{2}$ concentration and promote metabolic adaptation are nuclear factor- $\kappa B$ (NF- $\kappa B$ ) and activator protein-1 (AP1). Some of the mechanisms by which low $\mathrm{O}_{2}$ influences stem cell behavior rely on

\footnotetext{
${ }^{1}$ As defined elsewhere [2], normal $\mathrm{O}_{2}$ concentrations (physiological normoxia) for mammalian cells are those in the range of $2-9 \%$, and low $\mathrm{O}_{2}$ or physiological hypoxia is defined as concentrations below that range. The $\mathrm{O}_{2}$ atmospheric concentration is $21 \%$.
} 
activation of the Notch signaling pathway by HIF-1 $\alpha$ to maintain an undifferentiated state, whereas expression of OCT -4 , which controls stem cell renewal and pluripotency, is induced by HIF- $2 \alpha$. As discussed below, upon differentiation, a shift in $\mathrm{O}_{2}$ utilization occurs as mitogenesis increases, resulting in ROS production. In such conditions, HIF is suppressed by increased degradation and inhibited expression.

Regarding redox metabolism during differentiation, the challenge is to understand how cells adapt to $\mathrm{O}_{2}$ shifts during and after differentiation and which redox mechanisms underlie this process. Data accumulated thus far show that ROS function as signaling molecules to promote stem cell differentiation into cells of multiple lineages. The mechanisms underlying such process are regulated by intrinsic redox control in stem and progenitor cells through various redox signaling pathways. Mechanisms of redox signaling are based on specific redox reactions, mainly through oxidation and reduction of protein cysteine residues. Regardless, it is well known that ROS cause oxidative damage, and the redox modification of proteins can modulate their structure and activity, leading to the modulation of essential pathways in cell metabolism. Cell effectors susceptible to redox modulation are mainly kinases, phosphatases and transcription factors.

As previously noted [9], the increase in ROS levels as a population of stem cells differentiates can be taken as a paradigm. Low levels of ROS are required for quiescence and stem cell maintenance, whereas ROS induction would lead to proliferation and differentiation programs. Correspondingly, reports in the literature suggest an important intracellular pro-oxidative environment during differentiation because of increased mitochondrial ROS production. Increased production of either mitochondrial superoxide or cellular levels of other reactive oxygen species, together with the downregulation of major antioxidant genes, has been reported in human embryonic stem cell (ESC) lines upon differentiation [10]. Mitochondrial ROS generation was also shown to perform an important role in keratinocyte differentiation [11]. Mitochondrial transcription-factor A (TFAM)-deficient mice presented impaired epidermal differentiation and hair follicle growth. TFAM is required for the transcription of mitochondrial genes encoding electron transport chain subunits. To prove that mitochondrial ROS production underlies this process, keratinocytes were treated in vitro with antioxidants that inhibited differentiation. However, differentiation capability was recovered upon the application of exogenous $\mathrm{H}_{2} \mathrm{O}_{2}$. In hematopoietic stem cells (HSC), the deletion of the tuberous sclerosis complex (TSC), a mammalian target of the rapamycin mTOR pathway, drives quiescent mouse HSCs to differentiate and undergo increased mitogenesis, consequently resulting in elevated levels of ROS [12]. TSC deletion was shown to dramatically reduce hematopoiesis and HSC self-renewal, indicating that by repressing ROS production, HSCs can be maintained in a quiescent state. Regarding other redox regulators, FOXO-mediated transcription of genes encoding antioxidants has been implicated in the maintenance of stem cell populations, as deletion of Fox1, 3 and 4 in HSCs resulted in differentiation [13]. According to metabolomic studies [14], the activation of the oxidative metabolism during ESC differentiation was detected by changes in the GSH/GSSG ratios and ascorbate levels during the process of differentiation. Hydrogen peroxide levels were also shown to play a decisive role in either the maintenance or differentiation of HSCs [15]. At low levels, $\mathrm{H}_{2} \mathrm{O}_{2}$ maintains the quiescence of those cells, whereas high levels trigger proliferation, senescence or apoptosis. Human mesenchymal stem cell (MSC) differentiation to adipocytes or osteoblasts is regulated by specific redox states, including increased GSSG potential, as cells go through differentiation [16]. Increased ROS levels were also described upon the differentiation of neural stem cells $[17,18]$. These findings exemplify the increase in ROS production upon cellular differentiation.

Maintenance of the pluripotent state as well as differentiation are finely regulated processes at different levels. As proteins are considered to be major effectors of such processes, investigation of protein turnover (expression, translation and degradation) and post-translational and oxidative modifications are important matters for understanding differentiation. Baharvand and co-workers [19] found that 54 protein spots quantitatively changed and another 14 spots were qualitatively modified among human ESC cell lines during differentiation. In the same study, a large number of proteins found at high concentration were identified as chaperones, heat shock proteins, proteins of the ubiquitin/proteasome system, and oxidative stress responsive proteins, suggesting a pro-oxidative environment and the ability of these cells to resist oxidative stress upon differentiation.

Intracellular protein degradation is a regulatory process of protein function, as it determines protein half-life and, importantly, prevents the accumulation of damaged proteins and/or of their aggregation. In this scenario, the proteasome is a major player, as it finely controls protein half-life, mainly through the degradation of poly-ubiquitylated substrates and unfolded or oxidatively modified proteins.

The present review focuses on the proteasomal role in the redox metabolism during cell differentiation.

\section{The ubiquitin-proteasome system}

The ubiquitin-proteasome system (UPS) is highly conserved in eukaryotes, from yeast to humans. Protein ubiquitylation is a finely tuned regulatory process of controlling intracellular protein half-life through degradation. The UPS is responsible for degradation of those proteins involved in processes related to the regulation of cell cycle, antigen presentation through MHC-I complexes, and signaling cascades that maintain homeostasis or trigger death. Proteasomal protein degradation plays two important roles: control of regulatory proteins and clearance of misfolded and oxidatively damaged proteins. Clearance of misfolded proteins, namely Endoplasmic Reticulum-Associated Degradation (ERAD), is accomplished through poly-ubiquitylation [20]. On the other hand, degradation of oxidatively modified proteins and of proteins presenting unstructured domains is attributed to the proteasome through a ubiquitin-independent process $[21,22]$.

\subsection{Protein ubiquitylation}

The process of ubiquitylation involves three steps of events, as follows: ATP-dependent ubiquitin activation by E1 enzymes followed by ubiquitin conjugation to E2 (conjugating) enzymes and, finally, the transfer of ubiquitin to protein substrates through E3 (ligases) proteins. The last step can be either enzymatic by transferring the ubiquitin moiety to E3-bound substrates (HECT E3 enzymes) or occur through the direct transfer of ubiquitin to the protein substrate by scaffolding of substrates to RING or U-BOX E3 proteins [23]. Ubiquitin ( $8.5 \mathrm{kDa}$ ) is one of the most conserved eukaryotic proteins and is encoded in human DNA by the poly-ubiquitin genes Ubb and Ubc and the constitutive monomeric ubiquitin ribosomal fusion gene [24]. As ubiquitin is highly conserved, only two human E1 isoforms transfer ubiquitin to dozens of E2 isoforms. On the other hand, E3 proteins are abundant, as they specifically interact with protein substrates. Approximately 1000 are predicted in the human genome [24].

The protein substrate is bound to the ubiquitin molecule through the interaction between the $\varepsilon-\mathrm{NH}_{2}$-Lys of the substrate and the C-terminus Gly residue of ubiquitin. The poly-ubiquitin chain is built up through the successive addition of ubiquitin molecules via the C-terminal Gly residue of one ubiquitin to a Lys residue of another ubiquitin molecule. Poly-ubiquitylation can generate multiple topological chains depending on which, among seven, ubiquitin-Lys residues (K6, K11, K27, K29, K33, $\mathrm{K} 48$, and K63) participates in the poly-ubiquitin chain formation. The orchestrated interactions between E3-substrates and E2-E3 complexes direct the ubiquitin-Lys residue, one of the seven cited above, to form the poly-ubiquitin chain that then determines the topological arrangement of the poly-ubiquitin chains [23,25]. Poly-ubiquitin chains through K48 linkages are related to the degradation of substrate, whereas other topological chains regulate substrate fate in diverse ways, such as protein degradation, apoptosis, signal transduction, gene transcription, DNA 
repair, cell cycle progression, immune responses, virus budding, protein trafficking, and receptor and channel endocytosis. Other small proteins, highly similar to ubiquitin, called ubiquitin-like proteins (UBL) can also modify protein substrates [26]. The fate of substrates modified by UBLs is generally related to other regulatory processes.

\subsection{The proteasome}

The proteasome is a multimeric and multicatalytic protease composed of a central cylindrical-shaped unit called 20S, which is flanked on one or both sides by regulatory units. The $19 \mathrm{~S}$ regulatory unit is the most abundant and is responsible for recognizing poly-ubiquitylated substrates [27]. The $19 \mathrm{~S}$ unit ( $900 \mathrm{kDa}$ ) is composed of 19 subunits with a topological distribution that resembles a base and a lid. An ATPase hexameric ring is part of the base together with four other subunits, among them two ubiquitin receptors. The lid consists of seven scaffold subunits (Rpn3, 5, 6, 7, 9, 12 and 15), the deubiquitylating enzyme Rpn11, and the Rpn8 subunit. Near atomic resolution (subnanometer-resolution) of the topological structure of the 19S regulatory unit has been matter of intensive investigation [28-30]. Such studies have answered important questions regarding the location and function of many subunits and the dynamics of the 19S interaction with the 20S core particle and substrates. However, the location and role of many 195 subunits are still ambiguous.

The $20 \mathrm{~S}$ proteasome is composed of two identical and central heptameric rings called $\beta$, which is flanked on both sides by two identical heptameric rings termed $\alpha$, which are involved in the control of the $20 \mathrm{~S}$ gating. Three catalytic sites are located in the central $\beta$ units ( $\beta 1, \beta 2$ and $\beta 5$ ), totalizing six sites. The $20 \mathrm{~S}$ is a threonine protease, and the catalytic sites cleave the protein substrate after acidic ( $\beta 1)$, basic $(\beta 2)$ and hydrophobic ( $\beta 5)$ residues. These activities are called chymotrypsin-like, trypsin-like and caspase-like, respectively. Protein fragments generated comprise 3 to 25 amino acids.

Alternative proteasomes are described such as the immune and thymus proteasomes, both of which contain alternative catalytic subunits. The immune proteasome contains $\beta 1 \mathrm{i}, \beta 2 \mathrm{i}$ and $\beta 5 \mathrm{i}$, while the thymus proteasome contains the thymus-specific subunit $\beta 5 t$ [31]. In both examples, respective constitutive catalytic subunits are replaced by these specific subunits, thereby changing the overall activity of the proteasome. As recently shown, when either the immune or thymus subunits are co-expressed in cells together with the standard subunits, they are preferentially selected for the assembly of the core particle over the standard counterparts [32]. The term immune proteasome was coined because the induction of the $\beta 1 \mathrm{i}, \beta 2 \mathrm{i}$ and $\beta 5 \mathrm{i}$ subunits was first verified upon $\gamma$-IFN treatment [33]. Therefore, the immune proteasome is found in several conditions independent on the immune response, as discussed below. More recently, an alternative 20S form expressed in male germ cells that replaces the constitutive $\alpha 4$-subunit by an alternative subunit ( $\alpha 4 s)$ has been described [34]. The functional role of this replacement has yet to be described.

The UPS participates in the fine regulation of cellular events because protein poly-ubiquitylation is a highly regulated process in all steps, including modulation in an oxidative fashion, as all steps of polyubiquitylation are carried out by proteins that are dependent on Cys residues (E1, E2 and-E3). Protein poly-ubiquitylation is triggered by post-translational modifications, e.g., phosphorylation [35]. Additionally, poly-ubiquitylation is dictated by the $\mathrm{N}$-end rule, in which the identity of destabilizing $\mathrm{N}$-terminal residue(s) next to the $\mathrm{N}$-terminal Met, termed degrons, determines an enzymatically orchestrated mechanism driving ubiquitylation [36].

\subsection{Proteasomal ubiquitin-independent degradation}

Studies using proteomic techniques indicate that $20 \%$ of intracellular proteins undergo proteasomal degradation independent of polyubiquitylation $[37,38]$. According to the $\mathrm{N}$-end rule [36,39], proteins can be modified by mild oxidation, which may augment their ubiquitylation due to oxidation-induced conformational changes to expose specific residues as targets for ubiquitylation. However, the main hypothesis to date is that the majority of oxidized proteins undergo degradation through the $20 \mathrm{~S}$ proteasome independent of poly-ubiquitylation [40]. The first lines of evidence were presented in the 1980s with the observation that the incubation of oxidized proteins with erythrocyte extracts resulted in degradation independent of ATP and, most importantly, that the non-oxidized form of model proteins was not degraded in the same conditions [41]. Since then, degradation of oxidized proteins by the $20 \mathrm{~S}$ proteasome has been extensively investigated through in vitro approaches and in cellular models [21]. Proteins go through oxidation by several mechanisms, generating amino acid side chain modifications [42] and consequent mild loss of secondary structure and exposing hydrophobic patches that can interact with the 20S proteasome [40]. To date, very few mechanisms of protein repair have been described. These are centered on repair of side chains of sulfurcontaining amino acids (Cys and Met; [43]. Degradation is therefore claimed to be the cellular mechanism that deals with oxidized proteins. This is an interesting mechanism of defense, as it overcomes the time and energy consumption kinetic of protein poly-ubiquitylation and further degradation, as previously demonstrated [44]. Many indirect data in the literature show the 20S proteasome as the main player in the degradation of oxidized proteins [21], e.g., a large pool of the free $20 \mathrm{~S}$ proteasome in several cell lines (around two third; [27]), uncoupling between 195 and 20 S particles during oxidative stress [45-48], transient inactivation of enzymes involved in protein ubiquitylation and deubiquitylation [49-51], higher susceptibility of the 19S regulatory particle to oxidation compared to the $20 \mathrm{~S}$ core $[45,52]$, and no preference for the ubiquitylation of oxidized proteins [53].

Although the presence of a free pool of the 20S proteasome is predicted inside cells [27], no systematic study has been reported to evaluate this pool upon differential redox status of cells. An important issue centers on the gating conformation of such pools. The latent $20 \mathrm{~S}$ proteasome form is believed to be in a closed conformation, which does not support the entrance of folded proteins [54]. However, as extensively investigated, a higher surface hydrophobicity of oxidized proteins is determinant for interaction with the 20S proteasome [38,55-58]. More recently, modulation of the yeast $20 \mathrm{~S}$ proteasome gating through an oxidative post-translational modification, namely S-glutathionylation, was demonstrated $[43,59]$. These studies showed gate opening of the 20S proteasome when the 76 Cys residue in the $\alpha 5$-subunit is S-glutathionylated and closure when this Cys residue is in the reduced form. The open conformation was shown to degrade oxidized or unstructured protein models at higher rates. Most likely, this mechanism is a regulatory modification to cope with decreased cellular reductive abilities when the oxidized pool of proteins is increased [43].

\subsection{The $11 S$ regulatory unit and immune 20 s proteasome as players in the degradation of oxidized proteins}

In recent years, participation of immune proteasomal forms, the $11 \mathrm{~S}$ regulatory unit and the 20S-modified proteasome carrying the catalytic immune subunits ( $\beta 1 \mathrm{i}, \beta 2 \mathrm{i}$ and $\beta 5 \mathrm{i}$ ), has been reported in cellular defense against oxidative stress [60-66] and in the induction of the immune $20 \mathrm{~S}$ proteasome in tumor cell lines, as illustrated [67].

The 11S unit, also called PA28 $\alpha \beta \gamma$ or REG $\alpha \beta \gamma$ [68], is expressed in higher eukaryotes. PA28 $\alpha$ and PA28 $\beta$ preferentially form a heteroheptamer, while PA28 $\gamma$ is a homoheptamer. Many studies have implicated PA28 $\alpha \beta$ in the production of peptides for MHC-class I presentation, although the mechanistic basis for this function remains elusive [69]. The 11S activator (PA28 $\alpha \beta$ heptamers) stimulates the degradation of peptides, while the $\gamma$-homoheptamer has been implicated in the degradation of regulatory folded proteins [70]. The 11S unit was previously considered to be an immune regulatory particle because it was first described upon $\gamma$-IFN challenge [71]. However, PA28 $\alpha \beta$ and 
the $20 \mathrm{~S}$ immune proteasome are induced during transient adaptation to oxidative stress $[63,65,66]$. The redox-responsive transcription factor Nrf2 is a key element for the induction of standard 20S subunits and of the PA28 $\alpha \beta$ regulator during adaptation to oxidative stress. The immune $20 \mathrm{~S}$ proteasomal subunits are also induced during the oxidative stress response, though the regulation of their increased expression is not known [65]. Correspondly, during IFN-induced oxidative stress the immune 20S proteasome is upregulated [72]. Most likely, the expression of these immune isoforms is to increase the rate of protein degradation to maintain proteostasis during IFN challenge $[73,74]$.

\section{Proteasomal protein degradation during cell differentiation}

Protein degradation is an important metabolic regulator of protein half-life, which, in turn, is important for regulation of almost every cellular function. As mentioned above, the main proteolytic system inside cells is the ubiquitin-proteasome. Undoubtedly, protein polyubiquitylation is the most important regulatory mechanism to finely control protein function. Accordingly, important findings on the control of differentiation by protein poly-ubiquitylation have been reported, as discussed below. Fig. 1 briefly summarizes the role of UPS during differentiation.

\subsection{The regulation of cell differentiation by poly-ubiquitylation}

Protein ubiquitylation modulates the stability and function of an important set of regulatory factors involved in biological processes such as entrance into and progression of the cell cycle [75]. Alterations in the abundance of some transcription factors result in the re-direction of cellular fate, e.g., from a pluripotent state to differentiation. At the level of post-translational protein modification, ubiquitylation specifies processes, such as protein poly-ubiquitylation, to control the pool of signaling proteins and transcription factors in stem cells. Some of these transcription factors are known as pluripotency factors, associated with the maintenance of pluripotency and the balance between stem cell self-renewal and differentiation. The abundance of pluripotency factors (Oct-4, Nanog and c-Myc) is regulated by poly-ubiquitylation to specify differentiation processes [76].

E3 ligases have their function and protein targets regulated by tissue-specific factors in a developmentally regulated step-wise fashion. Illustrating that process upon differentiation, the E3 ligase, namely $\mathrm{SCF}^{\mathrm{Fbxw7}}$ (SKP1-cullin-F-box Fbxw7), utilizes different substrates depending on cell type and the subsequent process. Silencing $\mathrm{SCF}^{\mathrm{Fbxw} 7}$ expression in ESC was shown to inhibit differentiation and to increase cell reprogramming by stabilizing the pluripotency factor c-Myc [77-79]. Silencing $\mathrm{SCF}^{\mathrm{Fbxw} 7}$ in the mouse brain inhibited neural stem cell differentiation and increased progenitor cell death due to c-Myc and Notch up-regulation $[80,81]$. Moreover, $\mathrm{SCF}^{\mathrm{Fbxw7}}$ inactivation impaired the differentiation of stem cells from hematopoietic, intestinal and liver lineages [77,82-84]. These examples illustrate that $\mathrm{SCF}^{\mathrm{Fbxw} 7}$ is a key component of differentiation and self-renewal of various stem cells lineage, which, in turn, might be attributed to differential regulation of this E3 ligase and/or of its substrates according to tissue specificity.

Osteogenesis is well-known model of cellular differentiation regulated by the UPS [85]. In addition to the regulation of the pluripotency factors mentioned above, the abundance of signaling proteins and transcriptional factors in the osteogenesis pathway is finely regulated. The E3 ligases Smurf1 and c-Cbl negatively regulate osteoblast differentiation by increasing the degradation of signaling proteins as JunB, Runx2 and MEKK by Smurf1 and STAT5 by c-Cbl [86-91]. Moreover, other E3 ligases play important role in osteogenesis by regulating Runx2, Osx, SMADs, and OASIS, among other proteins (Table 1).

Table 1 summarizes the major findings regarding the role of UPS through E3 ligases upon differentiation in several cellular lines and tissues.

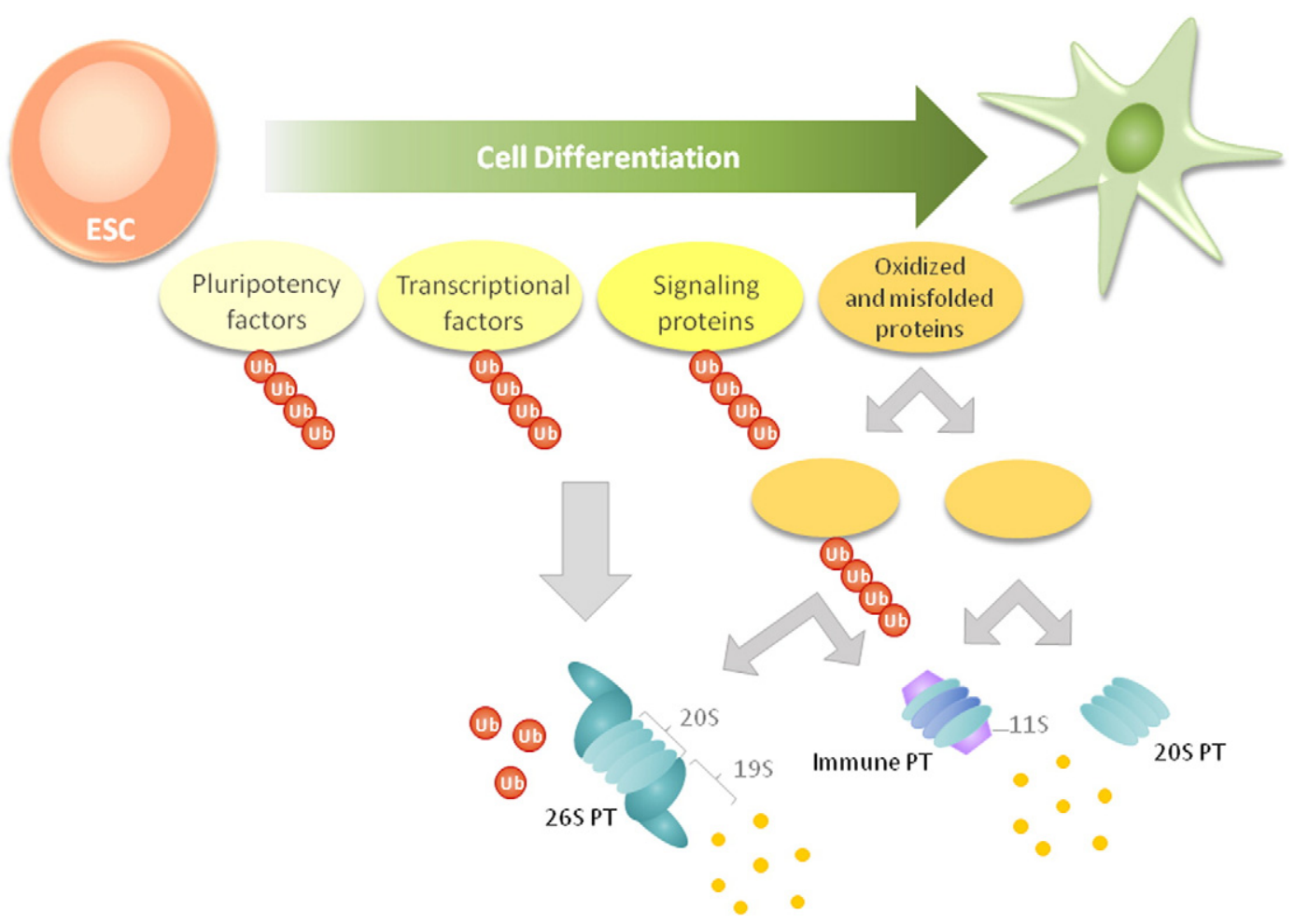

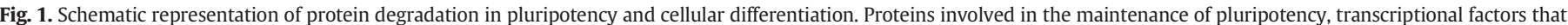

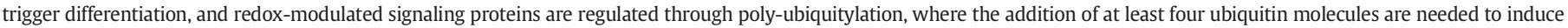

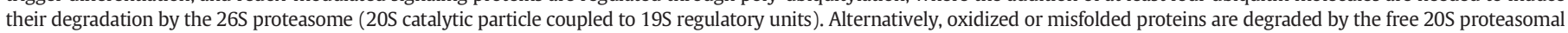
pool or by the 20S-11S complex and 20S immune isoforms in cells undergoing differentiation, as previously described and discussed in the present review. 
Table 1

E3 Ligases and their protein targets in cellular differentiation.

\begin{tabular}{|c|c|c|}
\hline E3-Ligase & Target & Reference \\
\hline \multirow[t]{7}{*}{$\mathrm{SCF}^{\mathrm{Fbxw7}}$} & Notch & {$[80,81,83,92-96]$} \\
\hline & c-Jun & {$[80,83,97]$} \\
\hline & c-Myc & {$[77-79,82,98-100]$} \\
\hline & $\mathrm{C} / \mathrm{EBP} \alpha$ & {$[101]$} \\
\hline & OASIS & [102] \\
\hline & BBF2H7 & [102] \\
\hline & KLF5 & [103] \\
\hline \multirow[t]{4}{*}{ WWP1 } & Jun-B & [104] \\
\hline & Runx2 & [105] \\
\hline & CXCR4 & [106] \\
\hline & Smad4 & [107] \\
\hline WWP2 & Oct-4 & [108-112] \\
\hline \multirow[t]{7}{*}{ Smurf } & $\beta$-catenina & [113] \\
\hline & Runx2 & {$[86,87,89]$} \\
\hline & Jun-B & {$[86,114]$} \\
\hline & MEKK2 & {$[88]$} \\
\hline & Smad1 & {$[86,89,115]$} \\
\hline & Smad5 & {$[116]$} \\
\hline & TGF- $\beta$ receptor & [117] \\
\hline $\mathrm{c}-\mathrm{Cbl}$ & STAT5 & {$[90]$} \\
\hline \multirow[t]{2}{*}{ Itch } & CXCR4 & {$[118,119]$} \\
\hline & Notch & {$[120]$} \\
\hline Huwe1 & $\mathrm{N}-\mathrm{myc}$ & [121] \\
\hline $\mathrm{SCF}^{\beta-\operatorname{Trcp}}$ & REST & [122] \\
\hline Mbi1 & Notch & [123] \\
\hline CHIP & Runx2 & [124] \\
\hline E6AP & $\mathrm{C} / \mathrm{EBP} \alpha$ & [125] \\
\hline ASB4 & ID2 & [126] \\
\hline Nedd4L & $\operatorname{Smad} 2 / 3$ & [127] \\
\hline \multirow[t]{2}{*}{ Unknown } & Nanog & {$[128,129]$} \\
\hline & Osx & {$[130]$} \\
\hline
\end{tabular}

Protein mono-ubiquitylation, usually associated to gene expression, is critical for ESC maintenance [131,132]. Conversely, H2B monoubiquitylation was shown to increase during differentiation of stem and precursor cells $[133,134]$.

\subsection{Ubiquitylation induced by protein redox regulation}

At the transcriptional level, cell differentiation is also regulated by the redox modification of transcription factors followed by their polyubiquitylation and consequent degradation. Examples are APE1/Ref-1, $\mathrm{HIF}$, and Nrf2/Keap1, which function mainly as central regulators of the cellular response to redox shifts and other essential pathways of cell metabolism and have been associated with cell differentiation programs.

APE1/Ref-1 (Apurinic/apyrimidinic endonuclease 1/redox effector factor-1, referred here as APE1) is a protein involved in the DNA baseexcision repair pathway and is a co-activator of some transcription factors that act as effectors of the oxidative stress response, such as NF-KB, HIF, and p53 [135]. APE1 is modulated by different post-translational modifications, such as phosphorylation, acetylation and ubiquitylation. Ubiquitylation of APE1 is regulated by the E3 ubiquitin ligases UBR3 and MDM2, depending on the cellular context [136-138]. APE1 participates in different cellular processes such as apoptosis, proliferation and differentiation [139]. Examples of cellular differentiation pathways regulated by APE1 are hematopoietic and neuronal differentiation of stem cells, both of which are dependent on the redox activity of APE1 but are independent of the DNA repair activity of APE1 [140,141]. During neuronal differentiation of human adult and embryonic stem cells, increased APE1-binding to chromatin is observed most likely because of the increased intracellular content of oxidants, which indicates an important redox function of APE1 in the neuronal differentiation process [141].

As already discussed above, oxygen availability in stem cell niches is an important factor that influences metabolism and differentiation.
Hypoxia-inducible factors (HIFs) are transcription factors that sense and regulate adaptive responses to low $\mathrm{O}_{2}$ tension. Under hypoxia, the HIF- $\alpha$ subunit (types 1,2 or 3 ) is stabilized to form a heterodimer complex with the HIF-1 $\beta$ subunit. This complex then translocates to the nucleus and binds to hypoxia-responsive elements to activate genes encoding proteins that mediate processes related to hematopoiesis, angiogenesis and erythropoiesis, promoting cell survival [2, 142-145]. Generally, hypoxia has been associated with enhanced stem cell pluripotency, while differentiation can be impaired or enhanced under hypoxia, depending on the cell type. HIF- $1 \alpha$ and HIF- $2 \alpha$ have been suggested to regulate stem cell function by altering Oct- 4 and c-Myc expression, both of which are essential for stem cell multipotency $[146,147]$. HIF- $1 \alpha$ is also involved in the Wnt/beta-catenin pathway under hypoxic conditions, which impairs cardiomyocyte differentiation in mouse iPS cells [148]. Under normoxic conditions, HIF- $1 \alpha$ is rapidly degraded by the ubiquitin-proteasome system. HIF$1 \alpha$ is hydroxylated at a specific prolyl residue by prolyl hydroxylase that is recognized by a von Hippel-Lindau (VHL) protein that, in complex with Elongin-C and Elongin-B, functions as an E3-ligase, driving HIF- $1 \alpha$ to proteasomal degradation [149]. The stability of HIF- $1 \alpha$ can also be regulated by the E3 ubiquitin ligases CHIP and HypoxiaAssociated Factor [150,151].

The transcription factor Nrf2 is a key regulator of the antioxidant response and of enzymes in phase II of detoxification [152]. Under normal, unstressed conditions, Nrf2 is localized mainly in the cytoplasm where it is bound to the repressor Keap1 protein (Kelch-like ECHassociated protein 1 ), which targets Nrf2 for ubiquitylation and subsequent degradation by a Cul3 (cullin 3)-mediated ubiquitylation complex $[153,154]$. Keap-1 acts as a redox sensor. When Keap1 cysteines are oxidized, Nrf2 is released and migrates to the nucleus where it induces the expression of genes related to anti-oxidant defense and proteasome subunits as well as their assembly through the induction of the POMP chaperone, a proteasome maturation protein [153].

In stem cell differentiation, the Keap1-Nrf2 axis inhibits RANKLinduced osteoclast differentiation via ROS reduction, regulates the cell fate of HSCs, and promotes neuronal cell differentiation. [155-159]. Nrf2 was also shown to control self-renewal and pluripotency in hESCs by regulating proteasome expression [152].

\subsection{Degradation of oxidized and misfolded proteins during differentiation}

Although few reports in the literature have addressed the importance of proteostasis during differentiation to date, the fine regulation of malformed or oxidized protein clearance is expected. ERAD plays a fundamental role in the clearance of malformed proteins. ERAD is a UPS-dependent process [160]. On the other hand, the clearance of metabolically oxidized proteins is mainly supported by the free pool of the $20 \mathrm{~S}$ core particle. As cells going through differentiation are under important pro-oxidative challenge, the pool of oxidized proteins is expected to increase. As discussed earlier in this review, mildly oxidized proteins are preferentially degraded by the $20 \mathrm{~S}$ proteasome by a process independent of poly-ubiquitylation and ATP consumption. When cells go through an oxidative imbalance, one of the cellular defenses to maintain surveillance of the proteome is the unfolded protein response (UPR) to prevent the accumulation of misfolded proteins [161]. Quality control of mitochondrial proteins is achieved by chaperones and proteases, the so-called mitoUPR [162]. In the case of stem cells, reports in the literature have shown ESCs to have a high ability to respond to protein misfolding, as these cells have increased levels of heat-shock proteins when compared to differentiated cells [163]. Undifferentiated mouse ESCs were shown to contain high levels of protein carbonyls and the so-called AGE (advanced glycation end products), hallmarks of protein oxidation during the aging process [164]. Increased ability of cells to rid themselves of oxidized proteins upon differentiation was observed by comparing the content of oxidized proteins in the inner cell mass of blastocysts to that of cells differentiated to the 
trophectoderm [164]. Notably, removal of oxidatively modified proteins during ESC differentiation was associated with increased expression of the proteasomal activator PA28 and of the immune proteasome subunits [165]. Upregulation of the immune 20S proteasome was also identified upon skeletal muscle differentiation and the knockdown of the immune proteasome catalytic subunit PSMB9 or the utilization of specific immune proteasome inhibitors, prevented differentiation of skeletal muscle cells [166]. Most interesting, suppression of the immune proteasome increased the pool of oxidized proteins and pro-apoptotic proteins. These results point to an increased oxidative environment during differentiation and to the important role of the $20 \mathrm{~S}$ immune proteasomal variants on the removal of oxidized proteins. In conclusion, despite little data regarding the role of the 20S free pool during cell differentiation, conditions during differentiation appear to resemble those due to mildly oxidative stress.

\section{Illustrating the role of UPS and redox regulation in pluripotency and differentiation of cardiomyocytes}

In the present review, an interactome was built using systems biology by comparing ESCs with terminally differentiated cardiomyocytes (CM) of Mus musculus to illustrate the role of UPS and redox regulation during differentiation.

Data collected from the M. musculus interactome network (Supplementary Material) using proteins related to differentiation, the proteasome and mechanisms of redox homeostasis generated a network containing 282 nodes and 3771 connectors (Fig. 2). Major components regarding proteasome- and ubiquitin-dependent processes were identified, such as components of the 26S proteasome (PSMA, PSMB, PSMC and PSMD), ubiquitin-activating enzyme E1 (Uba1), ubiquitinconjugating enzyme (UBE2C), and deubiquitylating enzymes (USP5; UCHL5). In addition, proteins associated with DNA repair (APEX1, RAD23A, RAD51; Table 2), anti-oxidant defense (PRDXs, CAT, SODs; Table 2) and development/cell differentiation (NOTCH1, SMAD3 and 4, among others; Table 2) were also observed in the interactome network (Fig. 2). By overlaying the interactome with RNA-sequence data and comparing ESCs with terminally differentiated cardiomyocytes (Supplementary Material), the following parameters were evaluated: (i) nodes under- and overexpressed in CMs compared to ESCs and (ii) major biologic processes transcriptionally regulated in CMs compared to ESCs (Figs. 3 and 4). Components of the cell cycle, ubiquitin-dependent processes, the stress response and anti-ROS defense (Table 2) were significantly underexpressed in CMs when compared to ESCs (Fig. 3).

Nodes representative of the UPS such as PSMD14, the deubiquitylating enzyme component of the proteasomal 19S regulatory particle as well as the E3 ligase $\mathrm{SCF}^{\mathrm{Fbxw} 7}$ were found to be underexpressed in $\mathrm{CMs}$ (Fig. 3). Notably, Psmd14 is a constitutive unit of the 26S proteasome, responsible for deubiquitylating substrates entering the catalytic chamber. PSMD14 has been shown to be a key component in the maintenance of ESC pluripotency [79]. Buckley and co-workers [79] have shown Psmd14 deubiquitylating activity as essential for pluripotency, as its overexpression inhibited differentiation. Moreover, these authors demonstrated that Psmd14-interacting proteins in the 19S lid are also important in the maintenance of pluripotency. Silencing Psmd11 and Psmd13,

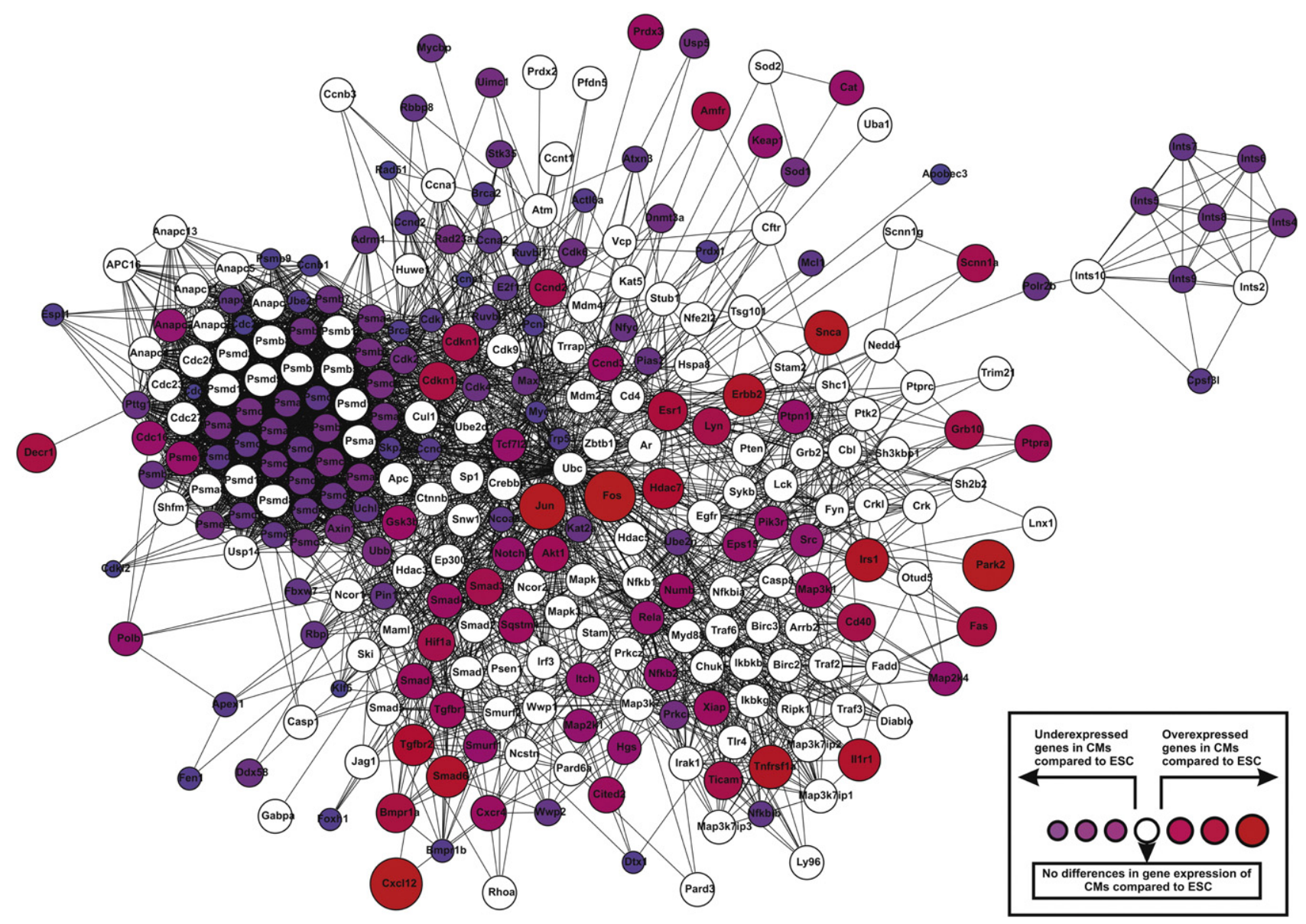

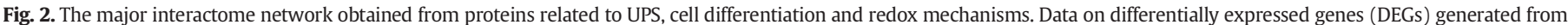

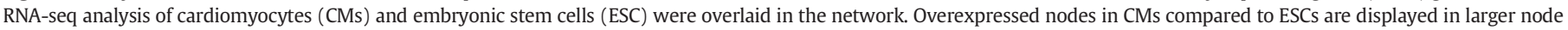

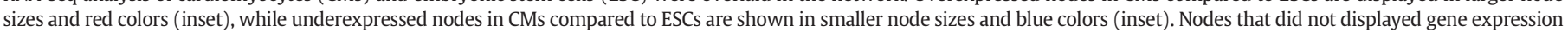
differences are indicated in white (inset). 
Table 2

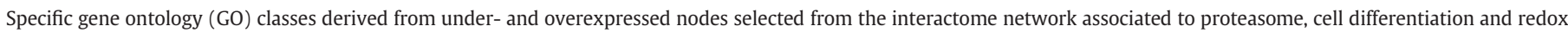
mechanisms.

\begin{tabular}{|c|c|c|c|c|c|c|c|}
\hline Node state & $\begin{array}{l}\text { GO biological } \\
\text { process category }\end{array}$ & $\begin{array}{l}\text { GO } \\
\text { number }\end{array}$ & $p$-value & $\begin{array}{l}\text { Corrected } \\
p \text {-value }\end{array}$ & $\mathrm{k}^{\mathrm{b}}$ & $\mathrm{f}^{\mathrm{c}}$ & Gene \\
\hline \multirow[t]{7}{*}{ Underexpressed } & Cell cycle & 7049 & $1.48 \times 10^{-18}$ & $1.01 \times 10^{-16}$ & 23 & 613 & $\begin{array}{l}\text { TRP53;E2F1;CDC6;CDK1;SKP2;BRCA2; CDC20;ANAPC10;ESPL1;CDK6; } \\
\text { PTTG1; CDK4;UBE2C;BRCA1;CDK2;RAD51; RBBP8;CCNB1;CCNE2; } \\
\text { CCNE1;CCND1; RUVBL1;CCNA2 }\end{array}$ \\
\hline & UPS & 6511 & $5.99 \times 10^{-15}$ & $3.26 \times 10^{-13}$ & 12 & 124 & $\begin{array}{l}\text { UBE2N;PSMA2;PSMA6;PSMA5;WWP2; RAD23A;USP5;PSMA4;PSMA3; } \\
\text { UCHL5;SKP2;PSMA7 }\end{array}$ \\
\hline & DNA repair & 6281 & $1.44 \times 10^{-14}$ & $6.52 \times 10^{-13}$ & 14 & 225 & $\begin{array}{l}\text { TRP53;RAD23A;BRCA2;PTTG1;SOD1;UIMC1;BRCA1;RAD51;UBE2N; } \\
\text { PCNA;PSMD4;RUVBL2;APEX1;FEN1 }\end{array}$ \\
\hline & Response to DNA damage & 6974 & $2.22 \times 10^{-14}$ & $9.67 \times 10^{-13}$ & 15 & 289 & $\begin{array}{l}\text { TRP53;CDK1;RAD23A;BRCA2;PTTG1;SOD1;UIMC1;BRCA1;RAD51; } \\
\text { UBE2N;PCNA; PSMD4;RUVBL2;APEX1;FEN1 }\end{array}$ \\
\hline & Response to stress & 6950 & $1.70 \times 10^{-9}$ & $3.19 \times 10^{-8}$ & 20 & 1243 & $\begin{array}{l}\text { TRP53;CDK1;RAD23A;BRCA2;PTTG1;SOD1;PRDX1;UIMC1;BRCA1; } \\
\text { RAD51;DDX58; UBE2N;CCND1;PCNA;PSMD4;RUVBL2; RBPJ;BMPR1B; } \\
\text { APEX1;FEN1 }\end{array}$ \\
\hline & $\begin{array}{l}\text { Cellular response to } \\
\text { reactive oxygen species }\end{array}$ & 34,614 & $3.96 \times 10^{-5}$ & $3.39 \times 10^{-4}$ & 3 & 21 & SOD1;APEX1;PRDX1 \\
\hline & $\begin{array}{l}\text { Cellular response to } \\
\text { superoxide }\end{array}$ & 71,451 & $1.48 \times 10^{-4}$ & $1.02 \times 10^{-3}$ & 2 & 6 & SOD1;PRDX1 \\
\hline \multirow[t]{6}{*}{ Overexpressed } & Organ development & 48,513 & $2.31 \times 10^{-18}$ & $2.64 \times 10^{-16}$ & 23 & 1680 & $\begin{array}{l}\text { LYN;ERBB2;TGFBR1;TGFBR2;SMAD4;ESR1;SMAD3;SMAD1;PRDX3;IRS1; } \\
\text { CXCL12; CITED2;AKT1;HIF1A;CDKN1B;CXCR4; GSK3B;JUN;MAP3K1; } \\
\text { NUMB;FAS;HDAC7; BMPR1A }\end{array}$ \\
\hline & $\begin{array}{l}\text { Positive regulation of cell } \\
\text { proliferation }\end{array}$ & 8284 & $2.63 \times 10^{-18}$ & $2.79 \times 10^{-16}$ & 15 & 386 & $\begin{array}{l}\text { LYN;ERBB2;TGFBR2;ESR1;CD40;CXCL12; IRS1;CDKN1A;CDKN1B;HIF1A; } \\
\text { CCND3; CCND2;JUN;TICAM1;BMPR1A }\end{array}$ \\
\hline & Cell differentiation & 30,154 & $5.72 \times 10^{-17}$ & $4.04 \times 10^{-15}$ & 22 & 1697 & $\begin{array}{l}\text { LYN;ERBB2;TGFBR1;PTPRA;TGFBR2; SMAD4;ESR1;SMAD3;SMAD1; } \\
\text { PRDX3; CXCL12;CITED2;AKT1;HIF1A;CXCR4; SQSTM1;GSK3B;JUN; } \\
\text { NUMB;FAS;HDAC7; BMPR1A }\end{array}$ \\
\hline & Immunological process & 2376 & $6.75 \times 10^{-16}$ & $2.94 \times 10^{-14}$ & 16 & 700 & $\begin{array}{l}\text { IL1R1;LYN;TGFBR1;SNCA;TGFBR2;SMAD3;CD40;PRDX3;CXCL12;AKT1; } \\
\text { HIF1A;CCND3;CXCR4;TICAM1;FAS;HDAC7 }\end{array}$ \\
\hline & $\begin{array}{l}\text { Blood vessel } \\
\text { development }\end{array}$ & 1568 & $1.06 \times 10^{-10}$ & $2.29 \times 10^{-9}$ & 9 & 265 & AKT1;HIF1A;CXCR4;JUN;TGFBR1;TGFBR2;CXCL12;HDAC7;CITED2 \\
\hline & Heart development & 7507 & $9.04 \times 10^{-7}$ & $7.10 \times 10^{-6}$ & 6 & 233 & HIF1A;TGFBR1;ERBB2;TGFBR2;SMAD3;BMPR1A \\
\hline
\end{tabular}

\footnotetext{
${ }^{\mathrm{a}}$ Values calculated from $p$-value after FDR application.

b Total number of genes found in the network that belong to a specific GO.

c Total number of genes belonging to a specific GO.
}

both Psmd14-interacting subunits, induced differentiation. Other components of the proteasome structure also appear to be significantly downregulated in the interactome network (Figs. 1 and 2), e.g., PSMC5 and PSMD7. Based on these data, the UPS seems to be essential for pluripotency. Accordingly, downregulation of the $\mathrm{E} 3$ protein $\mathrm{SCF}^{\mathrm{Fbxw}} 7$ was shown to control c-Myc protein stability to maintain the pluripotent state of ESCs [76]. These data highlight the importance of UPS integrity and functionality as a key system to maintain the pluripotent state.

Regarding the $20 \mathrm{~S}$ proteasome specifically, the node represented by PSMB9 (Fig. 3), a component of the immune proteasome that is shown to be underexpressed in CMs, was found to be essential for murine and human skeletal myoblast differentiation, as PSMB9 knockdown or specific immune proteasome inhibition prevented differentiation in the murine and human cellular models, respectively [166]. As discussed above (Section 3.3), the immune proteasome was found to be essential for the removal of oxidized proteins during differentiation.

In recent years, a growing set of information has identified ubiquitylation (formation of mono- or poly-ubiquitin chains) as an essential mechanism to accomplish the repair of various types of endogenous and exogenous DNA damage. Proteins directly involved in the ubiquitylation process itself form protein complexes that are required for recovery from DNA damage, including protein targets for ubiquitylation containing ubiquitin-binding domains and deubiquitylating enzymes [167]. As depicted in Figs. 2 and 3 and Table 2, many of the genes found to be downregulated in terminally differentiated cells are related to DNA repair and response to DNA damage stimulus. The components of nucleotide and base excision repair (NER and BER, respectively) such as APEX1 and FEN1 as well as some members of the recombination pathway (e.g., RAD51, BRCA1, BRCA2) display significant low gene expression in CMs when compared to ESCs. Both APEX1/REF1 and FEN1 are components of the BER pathway and are responsible for the removal of damaged bases from DNA, especially those that originated from the oxidative processes [168]. Apex1 is an apurinic/apyrimidic endodeoxyribonuclease whose inhibition by small interfering RNA in cardiac stem cells was shown to induce extensive apoptosis and cardiomyocyte differentiation [169]. On the other hand, FEN1, a 5'-flap endonuclease necessary for the repair of DNA damage induced by $\mathrm{H}_{2} \mathrm{O}_{2}$ [170], does not have a defined role in the maintenance of pluripotency. Similarly to APEX1, the expression of FEN1 in ESCs most likely impairs the promotion of cell differentiation. A potential mechanism where FEN1 may block cell differentiation might be related to the regulation/ control of the cell cycle, which is necessary for the maintenance of ESC self-renewal. In fact, high FEN1 protein levels are directly connected to the $S$ phase of the cell cycle, as FEN1 is further ubiquitylated and degraded by the proteasome after cells exit S phase [171]. Considering that ESCs display a long S phase [172], FEN1 most likely acts during S phase to promote genome, and consequently, the pluripotency of ESCs is maintained. The CDC6 gene, whose product is necessary for initiation of DNA replication and promotion of $S$ phase, was shown to be significantly downregulated in cardiomyocytes when compared to ESCs (Figs. 2 and 3). This finding supports the idea that maintenance of the cell cycle and, specifically, DNA replication and S phase, is essential to avoid cell differentiation.

Components of redox homeostasis, e.g., peroxiredoxin 1 (PRDX1) and, to a lesser extent, superoxide dismutase (SOD1), were found to be downregulated in CMs when compared to ESCs (Figs. 2 and 3). The role of both proteins in the self-renewal/pluripotency of ESCs is not clear. However, according to the interactome network (Fig. 2), a connection between PRDX1 and ADRM1 is depicted. Adrm1 is a proteasomal $19 \mathrm{~S}$ regulatory unit-associated protein that recruits ubiquitin carboxyl-terminal hydrolase L5 (UCHL5; Fig. 2), a deubiquitylating enzyme and a putative regulatory component of the chromatin remodeling complex INO80 [173]. Experimental data have pointed to an intricate cooperation among the INO80 complex, ADRM1 and UCHL5 in 


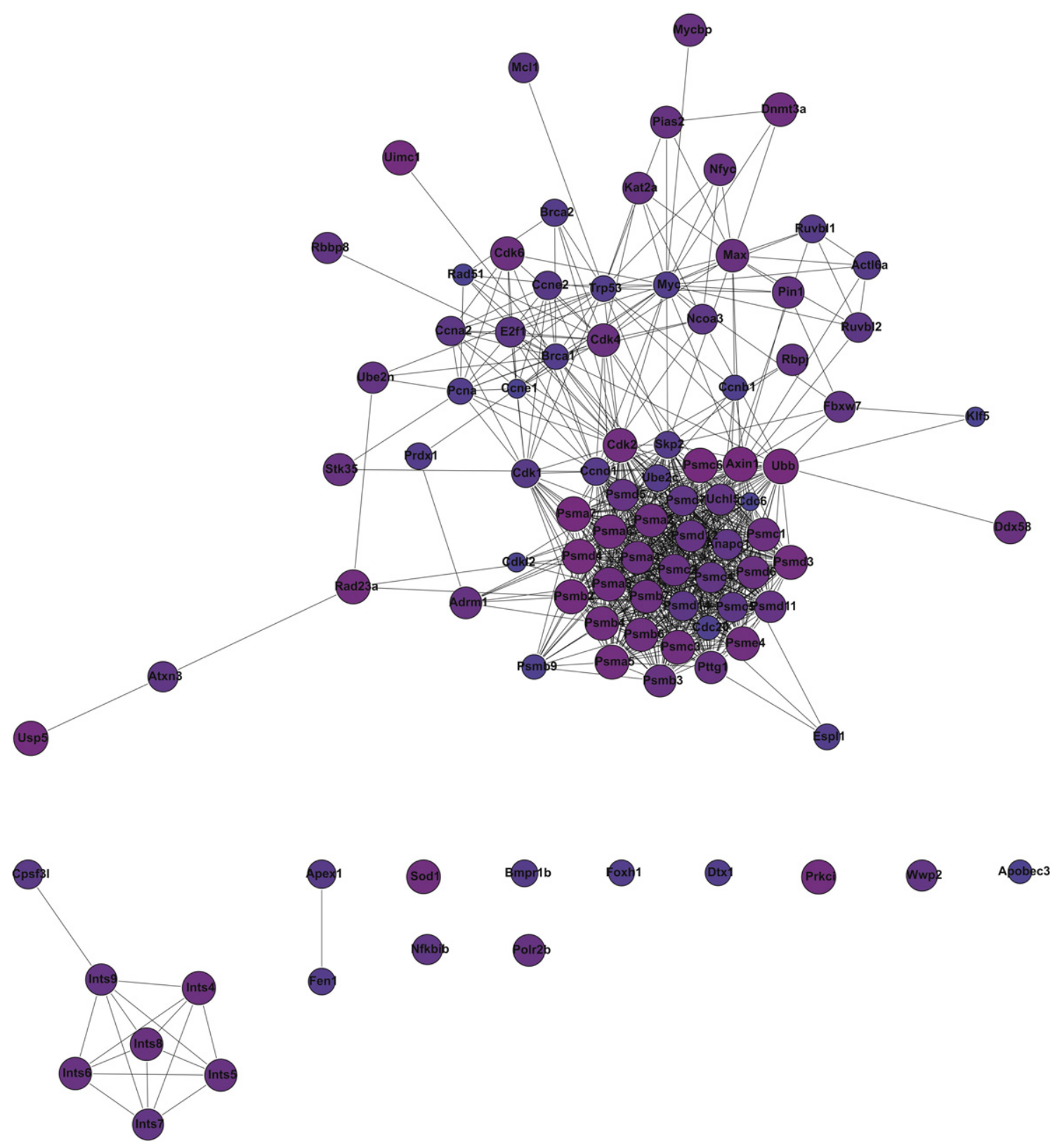

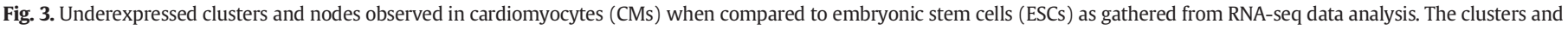
nodes indicated in this figure were selected from the major interactome network of proteins related to UPS, cell differentiation and redox mechanisms.

chromatin remodeling/gene expression and DNA repair [174]. Notably, the INO80 complex is necessary for ESC self-renewal/pluripotency [175]. This connection allows the hypothesis that PRDX1 is a redox sensor and thus a potential regulator of INO80 in ESCs.

Finally, data regarding the overexpressed genes in CMs compared to ESCs (Figs. 2 and 4; Table 2) indicate major biological processes related to organ, blood vessel and heart development, as they contain some overexpressed nodes already known to participate in stem cell differentiation, such as JUN and FOS, both of which are part of the AP-1 complex [176], and SMADs, a family of signal transduction genes activated in response to TGF- $\beta$ signaling [177]. However, some of the overexpressed genes are components of immune processes, e.g., CXCL2, a significantly overexpressed node (Figs. 2 and 4). CXCL2 encodes a stromal cellderived $\alpha$-chemokine, a member of the intercrine family whose product has been implicated in embryonic development [178]. Recently, Law and co-workers [178] demonstrated that, through an in vitro approach by inducing CM differentiation from ESCs, ROS signaling was associated with the modulation of the AP-1 complex and cytokine synthesis as part of the mechanism to enhance cardiomyogenesis from ESCs, suggesting the interplay of immune components with redox modulation. Additionally, the peroxiredoxin 3 node (PRDX3; Figs. 2 and 4 ) is likely part of the immune and differentiation processes (Table 1). PRDX3 has been implicated in proerythrocyte induction [179], but its role in ESC differentiation is unknown.

\section{Concluding remarks}

Pluripotency, self-renewal and differentiation in several cellular models (ESC, HSC and other stem cell lineages) are a matter of intense investigation, as comprehension of these processes implies a potential therapeutic application in many human diseases. Redox regulatory processes and UPS play important roles in the central steps of either pluripotency or differentiation. As noted in the present review, stem cells reside into low $\mathrm{O}_{2}$ niches. However, a wide range of $\mathrm{O}_{2}$ concentrations allows for 

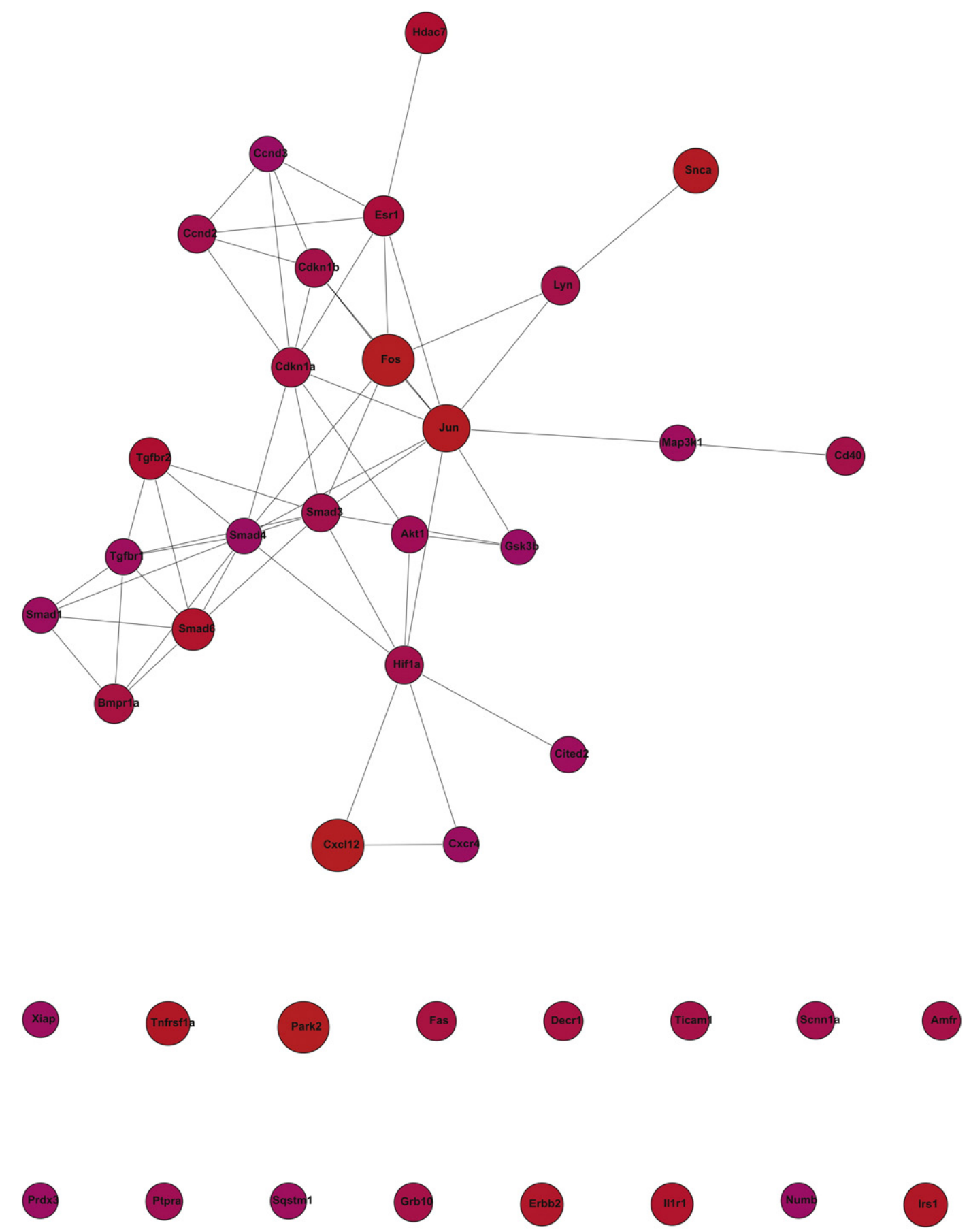

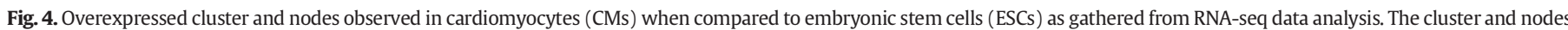
indicated in this figure were selected from the major interactome network of proteins related to UPS, cell differentiation and redox mechanisms.

differentiation resulting in the modulation of cell fate. In any condition, the ROS concentration is increased during differentiation, which most likely determines shifts in the activity of cellular effectors, such as kinases, phosphatases, and transcription factors, to trigger further steps of the process.

According to the data retrieved from the specific interactome network of cardiomyocytes differentiated from M. musculus ESCs, the role of UPS in the maintenance of pluripotency is noteworthy. Likewise, genome stability is likely essential for the pluripotency state. On the other hand, as cells differentiate, genes related to development and immune modulation prevail as shown by the overexpression of genes relying on both processes. Remarkably, the latter set of genes was found to be intimately related to redox modulation, as the PRDX3 node is linked to the immune response of differentiated cells.

\section{Acknowledgments}

Authors are supported by São Paulo State Research Foundation (FAPESP; grants 2009/54764-6 and 2011/23268-3); National Institute of Science, Technology and Innovation of Redox Processes in Biomedicine (INCT Redoxome supported by CNPq; grant 573530/2008-4, FAPESP, CAPES). 


\section{Appendix A. Supplementary data}

Supplementary data to this article can be found online at http://dx. doi.org/10.1016/j.bbagen.2014.10.031.

\section{References}

[1] M. Csete, Oxygen in the cultivation of stem cells, Ann. N. Y. Acad. Sci. 1049 (2005) $1-8$

[2] M.C. Simon, B. Keith, The role of oxygen availability in embryonic development and stem cell function, Nat. Rev. Mol. Cell Biol. 9 (2008) 285-296.

[3] J.R. Millman, J.H. Tan, C.K. Colton, The effects of low oxygen on self-renewal and differentiation of embryonic stem cells, Curr. Opin. Organ Transplant. 14 (2009) 694-700.

[4] Y. Yoshida, K. Takahashi, K. Okita, T. Ichisaka, S. Yamanaka, Hypoxia enhances the generation of induced pluripotent stem cells, Cell Stem Cell 5 (2009) 237-241.

[5] D. Wion, T. Christen, E.L. Barbier, J.A. Coles, $\mathrm{PO}_{2}$ matters in stem cell culture, Cell Stem Cell 5 (2009) 242-243.

[6] G.M. Morriss, D.A. New, Effect of oxygen concentration on morphogenesis of cranial neural folds and neural crest in cultured rat embryos, J. Embryol. Exp. Morpholog. 54 (1979) 17-35.

[7] K. Si-Tayeb, F.K. Noto, M. Nagaoka, J. Li, M.A. Battle, C. Duris, P.E. North, S. Dalton, S.A. Duncan, Highly efficient generation of human hepatocyte-like cells from induced pluripotent stem cells, Hepatology 51 (2010) 297-305.

[8] G.L. Semenza, Regulation of mammalian $\mathrm{O}_{2}$ homeostasis by hypoxia-inducible factor 1, Annu. Rev. Cell Dev. Biol. 15 (1999) 551-578.

[9] R.B. Hamanaka, N.S. Chandel, Mitochondrial reactive oxygen species regulate cellular signaling and dictate biological outcomes, Trends Biochem. Sci. 35 (2010) 505-513.

[10] G. Saretzki, T. Walter, S. Atkinson, J.F. Passos, B. Bareth, W.N. Keith, R. Stewart, S. Hoare, M. Stojkovic, L. Armstrong, T. von Zglinicki, M. Lako, Downregulation of multiple stress mechanisms during differentiation of human embryonic stem cells, Stem Cells 26 (2008) 455-464.

[11] R.B. Hamanaka, A. Glasauer, P. Hoover, S. Yang, H. Blatt, A.R. Mullen, S. Getsios, C.J. Gottardi, R.J. DeBerardinis, R.M. Lavker, N.S. Chandel, Mitochondrial reactive oxygen species promote epidermal differentiation and hair follicle development, Sci. Signal. 6 (2013) ra8.

[12] C. Chen, Y. Liu, R. Liu, T. Ikenoue, K.L. Guan, Y. Liu, P. Zheng, TSC-mTOR maintain quiescence and function of hematopoietic stem cells by repressing mitochondrial biogenesis and reactive oxygen species, J. Exp. Med. 205 (2008) 2397-2408.

[13] Z. Tothova, R. Kollipara, B.J. Huntly, B.H. Lee, D.H. Castrillon, D.E. Cullen, E.P. McDowell, S. Lazo-Kallanian, I.R. Williams, C. Sears, S.A. Armstrong, E. Passegué, R.A. DePinho, D.G. Gilliland, FoxOs are critical mediators of hematopoietic stem cell resistance to physiologic oxidative stress, Cell 128 (2007) 325-339.

[14] O. Yanes, J. Clark, D.M. Wong, G.J. Patti, A. Sánchez-Ruiz, H.P. Benton, S.A. Trauger C. Desponts, S. Ding, G. Siuzdak, Metabolic oxidation regulates embryonic stem cell differentiation, Nat. Chem. Biol. 6 (2010) 411-417.

[15] N. Urao, M. Ushio-Fukai, Redox regulation of stem/progenitor cells and bone marrow niche, Free Radic. Biol. Med. 54 (2013) 26-39.

[16] B.R. Imhoff, J.M. Hansen, Differential redox potential profiles during adipogenesis and ostegenesis, Cell. Mol. Biol. Lett. 16 (2011) 149-161.

[17] J. Smith, E. Ladi, M. Mayer-Proschel, M. Noble, Redox state is a central modulator of the balance between self-renewal and differentiation in a dividing glial precursor cell, Proc. Natl. Acad. Sci. U. S. A. 97 (2000) 10032-10037.

[18] M. Tsatmali, E.C. Walcott, K.L. Crossin, Newborn neurons acquire high levels of reactive oxygen species and increased mitochondrial proteins upon differentiation from progenitors, Brain Res. 1040 (2005) 137-150.

[19] H. Baharvand, M. Hajheidari, S.K. Ashtiani, G.H. Salekdeh, Proteomic signature of human embryonic stem cells, Proteomics 6 (2006) 3544-3549.

[20] J.C. Christianson, Y. Ye, Cleaning up in the endoplasmic reticulum: ubiquitin in charge, Nat. Struct. Mol. Biol. 21 (2014) 325-335.

[21] T. Jung, B. Catalgol, T. Grune, The proteasomal system, Mol. Aspects Med. 30 (2009) 191-296.

[22] N. Chondrogianni, I. Petropoulos, S. Grimm, K. Georgila, B. Catalgol, B. Friguet, T. Grune, E.S. Gonos, Protein damage, repair and proteolysis, Mol. Aspects Med. 35 (2014) $1-71$

[23] R.J. Deshaies, C.A.P. Joazeiro, Ring domain E3 ubiquitin ligases, Annu. Rev. Biochem. 78 (2009) 399-434

[24] A.L. Schwartz, A. Ciechanover, Targeting proteins for destruction by the ubiquitin system: implications for human pathobiology, Annu. Rev. Pharmacol. Toxicol. 49 (2009) 73-96.

[25] C. Behrends, J.W. Harper, Constructing and decoding unconventional ubiquitin chains, Nat. Struct. Mol. Biol. 18 (2011) 520-528.

[26] A.G. van der Veen, H.L. Ploegh, Ubiquitin-like proteins, Annu. Rev. Biochem. 81 (2012) 323-357.

[27] B. Fabre, T. Lambour, L. Garrigues, M. Ducoux-Petit, F. Amalric, B. Monsarrat, O. Burlet-Schiltz, M.P. Bousquet-Dubouch, Label-free quantitative proteomics reveals the dynamic of the proteasome complexes composition and stoichiometry in wide range of human cell lines, J. Proteome Res. 13 (2014) 3027-3037.

[28] F. Beck, P. Unverdorben, S. Bohn, A. Schweitzer, G. Pfeifer, E. Sakata, S. Nickell, J.M. Plitzko, E. Villa, W. Baumeister, F. Förster, Near-atomic resolution structural mode of the yeast 26S proteasome, Proc. Natl. Acad. Sci. U. S. A. 109 (2012) 14870-14875.

[29] K. Lasker, F. Försterc, S. Bohnc, T. Walzthoenid, E. Villac, P. Unverdorbenc, F. Beck, R. Aebersoldd, A. Salia, W. Baumeisterc, Molecular architecture of the 26S proteasome holocomplex determined by an integrative approach, Proc. Natl. Acad. Sci. 109 (2012) 1380-1387.

[30] P. Sledz, F. Forster, W. Bauneister, Allosteric effects in the regulation of $26 \mathrm{~S}$ proteasome activities, Mol. Biol. 425 (2013) 1415-1423.

[31] A. Kniepert, M. Groettrup, The unique functions of tissue-specific proteasomes, Trends Biochem. Sci. 39 (2014) 17-24

[32] M. Bai, X. Zhao, K. Sahara, Y. Ohte, Y. Hirano, T. Kaneko, H. Yashiroda, S. Murata, Assembly mechanisms of specialized core particles of the proteasome, Biomol. 4 (2014) 662-677.

[33] V. Ortiz-Navarrete, A. Seelig, M. Gernold, S. Frentzel, P.M. Kloetzel, G.J. Hämmerling, Subunit of the '20S' proteasome (multicatalytic proteinase) encoded by the major histocompatibility complex, Nature 353 (1991) 662-664.

[34] H. Uechi, J. Hamazaki, S. Murata, Characterization of testis-specific proteasome subunit $\alpha 4$ s in mammals, J. Biol. Chem. 289 (2014) 12365-12374.

[35] A.V. Gomes, C. Zong, R.D. Edmondson, X. Li, E. Stefani, J. Zhang, R.C. Jones, S. Thyparambil, G.W. Wang, X. Qiao, F. Bardag-Gorce, P. Ping, Mapping the murine cardiac 26S proteasome complexes, Circ. Res. 99 (2006) 362-371.

[36] A. Varshavsky, The N-end rule pathway and regulation by proteolysis, Protein Sci. 20 (2011) 1298-1345.

[37] M. Orlowski, S. Wilk, Ubiquitin-independent proteolytic functions of the proteasome, Arch. Biochem. Biophys. 415 (2003) 1-5.

[38] J.M. Baugh, E.G. Viktorova, E.V. Pilipenko, Proteasomes can degrade a significant proportion of cellular proteins independent of ubiquitination, J. Mol. Biol. 386 (2009) 814-827.

[39] T. Tasaki, S.M. Sriram, K.S. Park, Y.T. Kwon, The N-end rule pathway, 812012. 261-289.

[40] K.J. Davies, Degradation of oxidized proteins by the 20 S proteasome, Biochimie 83 (2001) 301-310.

[41] K.J. Davies, A.L. Goldberg, Proteins damaged by oxygen radicals are rapidly degraded in extracts of red blood cells, J. Biol. Chem. 262 (1987) 8227-8234.

[42] E.R. Stadtman, Protein oxidation and aging, Free Radic. Res. 40 (2006) 1250-1258.

[43] M. Demasi, L.E. Netto, G.M. Silva, A. Hand, C.L. de Oliveira, R.N. Bicev, F. Gozzo, M.H. Barros, J.M. Leme, E. Ohara, Redox regulation of the proteasome via Sglutathionylation, Redox Biol. 2 (2013) 44-51.

[44] A. Peth, J.A. Nathan, A.L. Godberg, The ATP costs and time required to degrade ubiquitinated proteins by the 26S proteasome, J. Biol. Chem. 288 (2013) 29215-29222.

[45] T. Reinheckel, O. Ullrich, N. Sitte, T. Grune, Differential impairment of $20 \mathrm{~S}$ and $26 \mathrm{~S}$ proteasome activities in human hematopoietic K562 cells during oxidative stress, Arch. Biochem. Biophys. 377 (2000) 65-68.

[46] X. Wang, J. Yen, P. Kaiser, L. Huang, Regulation of the $26 \mathrm{~S}$ proteasome complex during oxidative stress, Sci. Signal. 3 (2010) ra88.

[47] T. Grune, B. Catalgol, A. Licht, G. Ermak, A.M. Pickering, J.K. Ngo, K.J. Davies, HSP70 mediates dissociation and reassociation of the $26 \mathrm{~S}$ proteasome during adaptation to oxidative stress, Free Radic. Biol. Med. 51 (2011) 1355-1364.

[48] N. Livnat-Levanon, E. Kevel, O. Kleifeld, D. Krutauz, A. Segref, T. Rinaldi, Z. Epapazoglou, M. Cohen, N. Reis, T. Hoppe, M.H. Glickman, Reversible 26S proteasome disassembly upon mitochondrial stress, Cell Rep. 7 (2014) 1-10.

[49] J. Jahngen-Hodge, M.S. Obin, X. Gong, F. Shang, T.R. Nowell Jr., J. Gong, H. Abasi, J. Blumberg, A. Taylor, Regulation of ubiquitin-conjugating enzymes by glutathione following oxidative stress, J. Biol. Chem. 272 (1997) 28218-28226.

[50] M. Obin, F. Shang, X. Gong, G. Handelman, J. Blumberg, A. Taylor, Redox regulation of ubiquitin-conjugating enzymes: mechanistic insights using the thiol-specific oxidant diamide, FASEB J. 12 (1998) 561-569.

[51] F.M. da Cunha, M. Demasi, A.J. Kowaltowski, Aging and calorie restriction modulate yeast redox state, oxidized protein removal, and the ubiquitin-proteasome system, Free Radic. Biol. Med. 51 (2011) 664-670.

[52] T. Reinheckel, N. Sitte, O. Ullrich, U. Kuckelkorn, K.J. Davies, T. Grune, Comparative resistance of the $20 \mathrm{~S}$ and $26 \mathrm{~S}$ proteasome to oxidative stress, Biochem. J. 335 (1998) 637-642.

[53] M. Kästle, S. Reeg, A. Rogowska-Wrzesinska, T. Grune, Chaperones, but not oxidized proteins, are ubiquitinated after oxidative stress, Free Radic. Biol. Med. 53 (2012) 1468-1477.

[54] M. Bajorek, M.H. Glickman, Keeper sat the final gates: regulatory complexes and gating of the proteasome channel, Cell. Mol. Life Sci. 61 (2004) 1579-1588.

[55] R.E. Pacifici, Y. Kono, K.J. Davies, Hydrophobicity as the signal for selective degradation of hydroxyl radical-modified hemoglobin by the multicatalytic proteinase complex, proteasome, J. Biol. Chem. 268 (1993) 15405-15411.

[56] D.A. Ferrington, H. Sun, K.K. Murray, J. Costa, T.D. Williams, D.J. Bigelow, T.C. Squier, Selective degradation of oxidized calmodulin by the $20 \mathrm{~S}$ proteasome, J. Biol. Chem. 276 (2001) 937-943.

[57] C.W. Liu, M.J. Corboy, G.N. DeMartino, P.J. Thomas, Endoproteolytic activity of the proteasome, Science 299 (2003) 408-411.

[58] D.M. Smith, S.C. Chang, S. Park, D. Finley, Y. Cheng, A.L. Goldberg, Docking of the proteasomal ATPases' carboxyl termini in the 20S proteasome's $\alpha$ ring opens the gate for substrate entry, Mol. Cell 27 (2007) 731-744

[59] G.M. Silva, L.E. Netto, V. Simões, L.F. Santos, F.C. Gozzo, M.A. Demasi, C.L. Oliveira, R.N. Bicev, C.F. Klitzke, M.C. Sogayar, M. Demasi, Redox control of 20S proteasome gating, Antioxid. Redox Signal. 16 (2012) 1183-1194.

[60] D.A. Ferrington, A.D. Husom, L.V. Thompson, Altered proteasome structure, function, and oxidation in aged muscle, FASEB J. 19 (2005) 644-646.

[61] S. Kotamraju, S. Matalon, T. Matsunaga, T. Shang, J.M. Hickman-Davis, B. Kalyanaraman, Up-regulation of immunoproteasomes by nitric oxide. Potential antioxidative mechanism in endothelial cells, Free Radic. Biol. Med. 40 (2006) 1034-1044. 
[62] D.A. Ferrington, S.A. Hussong, H. Roehrich, R.J. Kapphahn, S.M. Kavanaugh, N.D. Heuss, D.S. Gregerson, Immunoproteasome responds to injury in the retina and brain, J. Neurochem. 106 (2008) 158-169.

[63] A.M. Pickering, A.L. Koop, C.Y. Teoh, G. Ermak, T. Grune, K.J. Davies, The immunoproteasome, the 20S proteasome and the PA28 $\alpha \beta$ proteasome regulator are oxidative-stress-adaptive proteolytic complexes, Biochem. J. 432 (2010) 585-594.

[64] J. Li, S.R. Powell, X. Wang, Enhancement of proteasome function by PA28 overexpression protects against oxidative stress, FASEB J. 25 (2011) 883-893.

[65] A.M. Pickering, R.A. Linder, H. Zhang, H.J. Forman, K.J. Davies, Nrf2-dependent induction of proteasome and $\mathrm{Pa} 28 \alpha \beta$ regulator are required for adaptation to oxidative stress, J. Biol. Chem. 287 (2012) 10021-10031.

[66] A.M. Pickering, K.J. Davies, Differential roles of proteasome and immunoproteasome regulators Pa28 $\alpha \beta, P a 28 \gamma$ and Pa200 in the degradation of oxidized proteins, Arch. Biochem. Biophys. 523 (2012) 181-190.

[67] D. Niewerth, N.E. Franke, G. Jansen, Y.G. Assaraf, J. van Meerloo, C.J. Kirk, J. Degenhardt, J. Anderl, A.D. Schimmer, S. Zweegman, V. de Haas, T.M. Horton, G.J. Kaspers, J. Cloos, Higher ratio immune versus constitutive proteasome level as novel indicator of sensitivity of pediatric acute leukemia cells to proteasome inhibitors, Haematologica 98 (2013) 1896-1904.

[68] B.M. Stadtmuller, C.P. Hill, Proteasome activators, Mol. Cell 41 (2011) 8-19.

[69] M. Groettrup, C.J. Kirk, M. Basler, Proteasomes in immune cells: more than peptide producers? Nat. Rev. Immunol. 10 (2010) 73-78.

[70] I. Mao, J. Liu, H. Luo, REGgamma, a proteasome activator and beyond? Cell. Mol. Life Sci. 65 (2008) 3971-3980.

[71] B. Honoré, H. Leffers, P. Madsen, J.E. Celis, Interferon-gamma up-regulates a unique set of proteins in human keratinocytes. Molecular cloning and expression of the cDNA encoding the RGD-sequence-containing protein IGUP I-5111, Eur. J. Biochem. 218 (1993) 421-430.

[72] U. Seifert, L.P. Bialy, F. Ebstein, D. Bech-Otschir, A. Voigt, F. Schröter, T. Prozorovski, N. Lange, J. Steffen, M. Rieger, U. Kuckelkorn, O. Aktas, P.M. Kloetzel, E. Krüger, Immunoproteasomes preserve protein homeostasis upon interferon-induced oxidative stress, Cell 142 (2010) 613-624.

[73] P. Deol, D.M.W. Zaiss, J.J. Monaco, A.J.A.M. Sijts, Rates of processing determine the immunogenicity of immunoproteasome-generated epitopes, J. Immunol. 178 (2007) 7557-7562.

[74] M. Mishto, J. Liepe, K. Textoris-Taube, C. Keller, P. Henklein, M. Weberruß, B. Dahlmann, C. Enenkel, A. Voigt, U. Kuckelkorn, M.P. Stumpf, P.M. Kloetzel, Proteasome isoforms exhibit only quantitative differences in cleavage and epitope generation, Eur. J. Immunol. (2014), http://dx.doi.org/10.1002/eji.201444902 (Epub ahead of print).

[75] L. Yamasaki, M. Pagano, Cell cycle, proteolysis and cancer, Curr. Opin. Cell Biol. 16 (2004) 623-628

[76] A. Strikoudis, M. Guillamot, I. Aifantis, Regulation of stem cell function by protein ubiquitylation, EMBO Rep. 15 (2014) 365-382.

[77] B.J. Thompson, V. Jankovic, J. Gao, S. Buonamici, A. Vest, J.M. Lee, J. Zavadil, S.D. Nimer, I. Aifantis, Control of hematopoietic stem cell quiescence by the E3 ubiquitin ligase Fbw7, J. Exp. Med. 205 (2008) 1395-1408.

[78] L. Reavie, G. Della Gatta, K. Crusio, B. Aranda-Orgilles, S.M. Buckley, B. Thompson, E. Lee, J. Gao, A.L. Bredemeyer, B.A. Helmink, J. Zavadil, B.P. Sleckman, T. Palomero, A. Ferrando, I. Aifantis, Regulation of hematopoietic stem cell differentiation by a single ubiquitin ligase-substrate complex, Nat. Immunol. 11 (2010) 207-215.

[79] S.M. Buckley, B. Aranda-Orgilles, A. Strikoudis, E. Apostolou, E. Loizou, K. Moran-Krucio, C.L. Farnsworth, A.A. koller, R. Dasgupta, J.C. Silva, M. Stadtfeld, K. Hochedilinger, E.I. Chen, I. Aifantis, Regulation of pluripotency and cellular reprogramming by the ubiquitin-proteasome system, Cell Stem Cell 11 (2012) 783-798.

[80] J.D. Hoeck, A. Jandke, S.M. Blake, E. Nye, B. Spencer-Dene, S. Brandner, A. Behrens, Fbw7 controls neural stem cell differentiation and progenitor apoptosis via Notch and c-Jun, Nat. Neurosci. 13 (2010) 1365-1372.

[81] A. Matsumoto, I. Onoyama, T. Sunabori, R. Kageyama, H. Okano, K.I. Nakayama, Fbxw7-dependent degradation of Notch is required for control of "stemness" and neuronal-glial differentiation in neural stem cells, J. Biol. Chem. 286 (2011) 13754-13764.

[82] S. Matsuoka, Y. Oike, I. Onoyama, A. Iwama, F. Arai, K. Takubo, Y. Mashimo, H. Oguro, E. Nitta, K. Ito, K. Miyamoto, H. Yoshiwara, K. Hosokawa, Y. Nakamura, Y. Gomei, H. Iwasaki, Y. Hayashi, Y. Matsuzaki, K. Nakayama, Y. Ikeda, A. Hata, S. Chiba, K.I. Nakayama, T. Suda, Fbxw7 acts as a critical fail-safe against premature loss of hematopoietic stem cells and development of T-ALL, Genes Dev. 22 (2008) 986-991.

[83] R. Babaei-Jadidi, N. Li, A. Saadeddin, B. Spencer-Dene, A. Jandke, B. Muhammad, E.E. Ibrahim, R. Muraleedharan, M. Abuzinadah, H. Davis, A. Lewis, S. Watson, A. Behrens, I. Tomlinson, A.S. Nateri, FBXW7 influences murine intestinal homeostasis and cancer, targeting Notch, Jun, and DEK for degradation, J. Exp. Med. 208 (2011) 295-312.

[84] I. Onoyama, A. Suzuki, A. Matsumoto, K. Tomita, H. Katagiri, Y. Oike, K. Nakayama, K.I. Nakayama, Fbxw7 regulates lipid metabolism and cell fate decisions in the mouse liver, J. Clin. Invest. 121 (2011) 342-354.

[85] N. Sévère, F.X. Dieudonné, P.J. Marie, E3 ubiquitin ligase-mediated regulation of boné formation and tumorigenesis, Cell Death Dis. 4 (2013) e463.

[86] M. Zhao, M. Qiao, B.O. Oyajobi, G.R. Mundy, D. Chen, E3 ubiquitin ligase Smurf1 mediates core-binding factor alpha1/Runx2 degradation and plays a specific role in osteoblast differentiation, J. Biol. Chem. 278 (2003) 27939-27944.

[87] M. Zhao, M. Qiao, S.E. Harris, B.O. Oyajobi, G.R. Mundy, D. Chen, Smurf1 inhibits osteoblast differentiation and bone formation in vitro and in vivo, J. Biol. Chem. 279 (2004) 12854-12859.

[88] M. Yamashita, S.X. Ying, G.M. Zhang, C. Li, S.Y. Cheng, C.X. Deng, Y.E. Zhang, Ubiquitin ligase Smurf1 controls osteoblast activity and bone homeostasis by targeting MEKK2 for degradation, Cell 121 (2005) 101-113.
[89] R. Guo, M. Yamashita, O. Zhang, Q. Zhou, D. Chen, D.G. Reynolds, H.A. Awad, L Yanoso, L. Zhao, E.M. Schwarz, Y.E. Zhang, B.F. Boyce, L. Xing, Ubiquitin ligase Smurf1 mediates tumor necrosis factorinduced systemic bone loss by promoting proteasomal degradation of bone morphogenetic signaling proteins, J. Biol. Chem. 283 (2008) 23084-23092.

[90] Y.W. Qiang, B. Hu, Y. Chen, Y. Zhong, B. Shi, B. Barlogie, J.D. Shaughnessy Jr., Bortezomib induces osteoblast differentiation via Wnt-independent activation of beta-catenin/TCF signaling, Blood 113 (2009) 4319-4330.

[91] F.X. Dieudonne, N. Sévère, M. Biosse-Duplan, J.J. Weng, Y. Su, P.J. Marie, Promotion of osteoblast differentiation in mesenchymal cells through Cbl-mediated control of STAT5 activity, Stem Cells 31 (2013) 1340-1349.

[92] I. Onoyama, R. Tsunematsu, A. Matsumoto, T. Kimura, I.M. de Alborán, K. Nakayama, K.I. Nakayama, Conditional inactivation of Fbxw7 impairs cell-cycle exit during $\mathrm{T}$ cell differentiation and results in lymphomatogenesis, J. Exp. Med. 204 (2007) 2875-2888.

[93] R. Tsunematsu, K. Nakayama, Y. Oike, M. Nishiyama, N. Ishida, S. Hatakeyama, Y Bessho, R. Kageyama, T. Suda, K.I. Nakayama, Mouse Fbw7/Sel-10/Cdc4 is required for notch degradation during vascular development, J. Biol. Chem. 279 (2004) 9417-9423.

[94] N. Gupta-Rossi, O. Le Bail, H. Gonen, C. Brou, F. Logeat, E. Six, A. Ciechanover, A Israël, Functional interaction between SEL-10, an F-box protein, and the nuclear form of activated Notch1 receptor, J. Biol. Chem. 276 (2001) 34371-34378.

[95] C. Oberg, J. Li, A. Pauley, E. Wolf, M. Gurney, U. Lendahl, The Notch intracellular domain is ubiquitinated and negatively regulated by the mammalian Sel-10 homolog, J. Biol. Chem. 276 (2001) 35847-35853.

[96] A. Jandke, C. Da Costa, R. Sancho, E. Nye, B. Spencer-Dene, A. Behrens, The F-box protein Fbw7 is required for cerebellar development, Dev. Biol. 358 (2011) 201-212.

[97] A.S. Nateri, L. Riera-Sans, C. Da Costa, A. Behrens, The ubiquitin ligase SCFFbw7 antagonizes apoptotic JNK signaling, Science 303 (2004) 1374-1378.

[98] M. Welcker, A. Orian, J.E. Grim, R.N. Eisenman, B.E. Clurman, A nucleolar isoform of the Fbw7 ubiquitin ligase regulates c-Myc and cell size, Curr. Biol. 14 (2004) 1852-1857.

[99] M. Yada, S. Hatakeyama, T. Kamura, M. Nishiyama, R. Tsunematsu, H. Imaki, N Ishida, F. Okumura, K. Nakayama, K.I. Nakayama, Phosphorylation-dependent degradation of c-Myc is mediated by the F-box protein Fbw7, EMBO J. 23 (2004) $2116-2125$.

[100] B. King, T. Trimarchi, L. Reavie, L. Xu, J. Mullenders, P. Ntziachristos, B. ArandaOrgilles, A. Perez-Garcia, J. Shi, C. Vakoc, P. Sandy, S.S. Shen, A. Ferrando, I. Aifantis, The ubiquitin ligase FBXW7 modulates leukemia-initiating cell activity by regulating MYC stability, Cell 153 (2013) 1552-1566.

[101] M.T. Bengoechea-Alonso, J. Ericsson, The ubiquitin ligase Fbxw7 controls adipocyte differentiation by targeting C/EBPalpha for degradation, Proc. Natl. Acad. Sci. U. S. A 107 (2010) 11817-11822.

[102] K. Yumimoto, M. Matsumoto, I. Onoyama, K. Imaizumi, K.I. Nakayama, F-box and WD repeat domain-containing-7 (Fbxw7) protein targets endoplasmic reticulumanchored osteogenic and chondrogenic transcriptional factors for degradation, J. Biol. Chem. 288 (2013) 28488-28502.

[103] S. Kumadaki, T. Karasawa, T. Matsuzaka, M. Ema, Y. Nakagawa, M. Nakakuki, R. Saito, N. Yahagi, H. Iwasaki, H. Sone, K. Takekoshi, S. Yatoh, K. Kobayashi, A. Takahashi, H. Suzuki, S. Takahashi, N. Yamada, H. Shimano, Inhibition of ubiquitin ligase F-box and WD repeat domain-containing 7 (Fbw7) causes hepatosteatosis through Krüppel-like factor 5 (KLF5)/peroxisome proliferator-activated receptor 2 (PPAR2) pathway but not SREBP-1c protein in mice, J. Biol. Chem. 286 (2011) 40835-40846.

[104] L. Zhao, J. Huang, H. Zhang, Y. Wang, L.E. Matesic, M. Takahata, H. Awad, D. Chen, L. Xing, Tumor necrosis factor inhibits mesenchymal stem cell differentiation into osteoblasts via the ubiquitin E3 ligase Wwp1, Stem Cells 29 (2011) 1601-1610.

[105] D.C. Jones, M.N. Wein, L.H. Glimcher, Schnurri3: a key regulator of postnatal skeletal remodeling, Adv. Exp. Med. Biol. 602 (2007) 1-13.

[106] K. Subik, L. Shu, C. Wu, Q. Liang, D. Hicks, B. Boyce, L. Schiffhauer, D. Chen, C Chen, L. Xing Tang, The ubiquitin E3 ligase WWP1 decreases CXCL12-mediated MDA231 breast cancer cell migration and bone metastasis, Bone 50 (2012) 813-823.

[107] A. Moren, T. Imamura, K. Miyazono, A. Heldin, C.H. Moustakas, Degradation of the tumor suppressor Smad4 by WW and HECT domain ubiquitin ligases, J. Biol. Chem. 280 (2005) 22115-22123.

[108] G. Pirozzi, S.J. McConnell, A.J. Uveges, J.M. Carter, A.B. Sparks, B.K. Kay, D.M. Fowlkes, Identification of novel human WW domain-containing proteins by cloning of ligand targets, J. Biol. Chem. 272 (1997) 14611-14616.

[109] H.M. Xu, B. Liao, Q.J. Zhang, Wwp2, an E3 ubiquitin ligase that targets transcription factor Oct-4 for ubiquitination, J. Biol. Chem. 279 (2004) 23495-23503.

[110] H. Xu, W. Wang, C. Li, H. Yu, A. Yang, B. Wang, Y. Jin, WWP2 promotes degradation of transcription factor OCT4 in human embryonic stem cells, Cell Res. 19 (2009) 561-573.

[111] B. Liao, Y. Jin, Wwp2 mediates Oct4 ubiquitination and its own auto-ubiquitination in a dosage-dependent manner, Cell Res. 20 (2010) 332-344.

[112] N. Cai, M. Li, J. Qu, G.H. Liu, J.C. Izpisua-Belmonte, Post-translational modulation of pluripotency, J. Mol. Cell Biol. 4 (2012) 262-265.

[113] J. Chang, F. Liu, M. Lee, B. Wu, K. Ting, J.N. Zara, C. Soo, K. Al Hezaimi, W. Zou, X. Chen, D.J. Mooney, C.Y. Wang, NF- $\kappa B$ inhibits osteogenic differentiation of mesenchymal stem cells by promoting $\beta$-catenin degradation, Proc. Natl. Acad. Sci. 110 (2013) 9469-9474.

[114] L. Zhao, J. Huang, R. Guo, Y. Wang, D. Chen, L. Xing, Smurf1 inhibits mesenchymal stem cell proliferation and differentiation into osteoblasts through JunB degradation, J. Bone Miner. Res. 25 (2010) 1246-1256. 
[115] H. Zhu, P. Kavsak, S. Abdollah, J.L. Wrana, G.H. Thomsen, A. SMAD, ubiquitin ligase targets the BMP pathway and affects embryonic pattern formation, Nature 400 (1999) 687-693.

[116] S.X. Ying, Z.J. Hussain, Y.E. Zhang, Smurf1 facilitates myogenic differentiation and antagonizes the bone morphogenetic protein-2-induced osteoblast conversion by targeting Smad5 for degradation, J. Biol. Chem. 278 (2003) 39029-39036.

[117] P. Kavsak, R.K. Rasmussen, C.G. Causing, S. Bonni, H. Zhu, G.H. Thomsen, J.L. Wrana, Smad7 binds to Smurf2 to form an E3 ubiquitin ligase that targets the TGF-b receptor for degradation, Mol. Cell 6 (2000) 1365-1375.

[118] A. Marchese, C. Raiborg, F. Santini, J.H. Keen, H. Stenmark, J.L. Benovic, The E3 ubiquitin ligase AIP4 mediates ubiquitination and sorting of the $G$ protein coupled receptor CXCR4, Dev. Cell 5 (2003) 709-722.

[119] C. Rathinam, L.E. Matesic, R.A. Flavell, The E3 ligase Itch is a negative regulator of the homeostasis and function of hematopoietic stem cells, Nat. Immunol. 12 (2011) 399-407.

[120] L. Qiu, C. Joazeiro, N. Fang, H.Y. Wang, C. Elly, Y. Altman, D. Fang, T. Hunter, Y.C. Liu, Recognition and ubiquitination of Notch by Itch, a hecttype E3 ubiquitin ligase, J. Biol. Chem. 275 (2000) 35734-35737.

[121] X. Zhao, J.I. Heng, D. Guardavaccaro, R. Jiang, M. Pagano, F. Guillemot, A. lavarone A. Lasorella, The HECT-domain ubiquitin ligase Huwe1 controls neural differentiation and proliferation by destabilizing the N-Myc oncoprotein, Nat. Cell Biol. 10 (2008) 643-653.

[122] T.F. Westbrook, G. Hu, X.L. Ang, P. Mulligan, N.N. Pavlova, A. Liang, Y. Leng, R. Maehr, Y. Shi, J.W. Harper, S.J. Elledge, SCFbeta-TRCP controls oncogenic transformation and neural differentiation through REST degradation, Nature 452 (2008) 370-374.

[123] B.K. Koo, H.S. Lim, R. Song, M.J. Yoon, K.J. Yoon, J.S. Moon, Y.W. Kim, M.C. Kwon, K.W. Yoo, M.P. Kong, J. Lee, A.B. Chitnis, C.H. Kim, Y.Y. Kong, Mind, bomb 1 is essential for generating functional Notch ligands to activate Notch, Development 132 (2005) 3459-3470.

[124] X. Li, M. Huang, H. Zheng, Y. Wang, F. Ren, Y. Shang, Y. Zhai, D.M. Irwin, Y. Shi, D. Chen, Z. Chang, CHIP promotes Runx2 degradation and negatively regulates osteoblast differentiation, J. Cell Biol. 181 (2008) 959-972.

[125] P. Pal, S. Lochab, J.K. Kanaujiya, I. Kapoor, S. Sanyal, G. Behre, A.K. Trivedi, E3 ubiquitin ligase E6AP negatively regulates adipogenesis by downregulating proadipogenic factor C/EBPalpha, PLoS ONE 8 (2013) e65330.

[126] W.H.D. Townley-Tilson, Y. Wu, J.E. Ferguson III, C. Patterson, The ubiquitin ligase ASB4 promotes trophoblast differentiation through the degradation of ID2, PLoS ONE 9 (2014) e89451.

[127] S. Gao, C. Alarcon, G. Sapkota, S. Rahman, P.Y. Chen, N. Goerner, M.J. Macias, H. Erdjument-Bromage, P. Tempst, J. Massagué, Ubiquitin ligase Nedd4L targets activated Smad2/3 to limit TGF-beta signaling, Mol. Cell 36 (2009) 457-468.

[128] S. Ramakrishna, B. Suresh, K.H. Lim, B.H. Cha, S.H. Lee, K.S. Kim, K.H. Baek, PEST motif sequence regulating human NANOG for proteasomal degradation, Stem Cells Dev. 20 (2011) 1511-1519.

[129] M. Moretto-Zita, H. Jin, Z. Shen, T. Zhao, S.P. Briggs, Y. Xu, Phosphorylation stabilizes Nanog by promoting its interaction with Pin1, Proc. Natl. Acad. Sci. U. S. A. 107 (2010) 13312-13317.

[130] Y. Peng, K. Shi, L. Wang, J. Lu, H. Li, S. Pan, C. Ma, Characterization of Osterix protein stability and physiological role in osteoblast differentiation, PLoS ONE 8 (2013) e56451.

[131] M. Endoh, T.A. Endo, T. Endoh, K. Isono, J. Sharif, O. Ohara, T. Toyoda, T. Ito, R. Eskeland, W.A. Bickmore, M. Vidal, B.E. Bernstein, H. Koseki, Histone H2A monoubiquitination is a crucial step to mediate PRC1-dependent repression of developmental genes to maintain ES cell identity, PLoS Genet. 8 (2012) e1002774.

[132] W. Yang, Y.H. Lee, A.E. Jones, J.L. Woolnough, D. Zhou, Q. Dai, O. Wu, K.E. Giles, T.M. Townes, $\mathrm{H}$. Wang, The histone H2A deubiquitinase Usp16 regulates embryonic stem cell gene expression and lineage commitment, Nat. Commun. 5 (2014) 3818-3833.

[133] G. Fuchs, E. Shema, R. Vesterman, E. Kotler, Z. Wolchinsky, S. Wilder, L. Golomb, A Pribluda, F. Zhang, M. Haj-Yahya, E. Feldmesser, A. Brik, X. Yu, J. Hanna, D. Aberdam, E. Domany, M. Oren, RNF20 and USP44 regulate stem cell differentiation by modulating H2B monoubiquitylation, Mol. Cell 46 (2012) 662-673.

[134] O. Karpiuk, Z. Najafova, F. Kramer, M. Hennion, C. Galonska, A. König, N. Snaidero, T. Vogel, A. Shchebet, Y. Begus-Nahrmann, M. Kassem, M. Simons, H. Shcherbata, T. Beissbarth, S.A. Johnsen, The histone H2B monoubiquitination regulatory pathway is required for differentiation of multipotent stem cells, Mol. Cell 46 (2012) 705-713.

[135] G. Tell, F. Quadrifoglio, C. Tiribelli, M.R. Kelley, The many functions of APE1/Ref-1: not only a DNA repair enzyme, Antioxid. Redox Signal. 11 (2009) 601-619.

[136] C.S. Busso, T. Iwakuma, T. Izumi, Ubiquitination of mammalian AP endonuclease (APE1) regulated by the p53-MDM2 signaling pathway, Oncogene 28 (2009) $1616-1625$

[137] C.S. Busso, C.M. Wedgeworth, T. Izumi, Ubiquitination of human AP-endonuclease 1 (APE1) enhanced by T233E substitution and by CDK5, Nucleic Acids Res. 39 (2011) 8017-8028.

138] C. Meisenberg P.S. Tait, L. Dianova, K. Wright, MJ. Edelmann, N. Ternette, T. Tasaki, B.M. Kessler, J.L. Parsons, Y.T. Kwon, G.L. Dianov, Ubiquitin ligase UBR3 regulates cellular levels of the essential DNA repair protein APE1 and is required for genome stability, Nucleic Acids Res. 40 (2012) 701-711.

[139] G. Tell, G. Damante, D. Caldwell, M.R. Kelley, The intracellular localization of APE1/ Ref-1: more than a passive phenomenon? Antioxid. Redox Signal. 7 (2005) 367-384.

[140] G.M. Zou, M.H. Luo, A. Reed, M.R. Kelley, M.C. Yoder, Ape1 regulates hematopoietic differentiation of embryonic stem cells through its redox functional domain, Blood 109 (2007) 1917-1922.
[141] R. Domenis, N. Bergamin, G. Gianfranceschi, C. Vascotto, M. Romanello, S. Rigo, G. Vagnarelli, M. Faggiani, P. Parodi, M.R. Kelley, C.A. Beltrami, D. Cesselli, G. Tell, A.P. Beltrami, The redox function of APE1 is involved in the differentiation process of stem cells toward a neuronal cell fate, PLoS ONE 9 (2014) e89232.

[142] G.L. Semenza, Hypoxia-inducible factor 1 (HIF-1) pathway, Sci. STKE (2007) 2007, $\mathrm{cm} 8$.

[143] T. Simsek, F. Kocabas, J. Zheng, R.J. DeBerardinis, A.I. Mahmoud, E.N. Olson, J.W. Schneider, C.C. Zhang, H.A. Sadek, The distinct metabolic profile of hematopoietic stem cells reflects their location in a hypoxic niche, Cell Stem Cell 7 (2010) 380-390.

[144] K. Takubo, N. Goda, W. Yamada, H. Iriuchishima, E. Ikeda, Y. Kubota, H. Shima, R.S. Johnson, A. Hirao, M. Suematsu, T. Suda, Regulation of the HIF- $1 \alpha$ level is essential for hematopoietic stem cells, Cell Stem Cell 7 (2010) 391-402.

[145] S. Palomäki, M. Pietilä, S. Laitinen, J. Pesälä, R. Sormunen, P. Lehenkari, P. Koivunen, HIF- $1 \alpha$ is upregulated in human mesenchymal stem cells, Stem Cells 31 (2013) 1902-1909.

[146] K.L. Covello, J. Kehler, H. Yu, J.D. Gordan, A.M. Arsham, C.J. Hu, P.A. Labosky, M.C. Simon, B. Keith, HIF-2alpha regulates Oct-4: effects of hypoxia on stem cell function, embryonic development, and tumor growth, Genes Dev. 20 (2006) 557-570.

[147] C.V. Dang, J.W. Kim, P. Gao, J. Yustein, The interplay between MYC and HIF in cancer, Nat. Rev. Cancer 8 (2008) 51-56

[148] T.L. Medley, M. Furtado, N.T. Lam, R. Idrizi, D. Williams, P.J. Verma, M. Costa, D.M. Kaye, Effect of oxygen on cardiac differentiation in mouse iPS cells: role of hypoxia inducible factor-1 and Wnt/Beta-catenin signaling, PLoS ONE 8 (2013) e80280.

[149] S. Salceda, J. Caro, Hypoxia-inducible factor 1alpha (HIF-1alpha) protein is rapidly degraded by the ubiquitin-proteasome system under normoxic conditions. Its stabilization by hypoxia depends on redox-induced changes, J. Biol. Chem. 272 (1997) 22642-22647.

[150] M.Y. Koh, B.G. Darnay, G. Powis, Hypoxia-associated factor, a novel E3-ubiquitin ligase, binds and ubiquitinates hypoxia-inducible factor $1 \alpha$, leading to its oxygenindependent degradation, Mol. Cell. Biol. 28 (2008) 7081-7095.

[151] C.F. Bento, R. Fernandes, J. Ramalho, C. Marques, F. Shang, A. Taylor, P. Pereira, The chaperone-dependent ubiquitin ligase CHIP targets HIF-1 $\alpha$ for degradation in the presence of methylglyoxal, PLoS ONE 5 (2010) e15062.

[152] J. Jang, Y. Wang, H.S. Kim, M.A. Lalli, K.S. Kosik, Nrf2, a regulator of the proteasome, controls self-renewal and pluripotency in human embryonic stem cells, Stem Cells 32 (2014) 2616-2625.

[153] M. McMahon, K. Itoh, M. Yamamoto, J.D. Hayes, Keap1-dependent proteasomal degradation of transcription factor Nrf2 contributes to the negative regulation of antioxidant response element-driven gene expression, J. Biol. Chem. 278 (2003) 21592-21600.

[154] M. Furukawa, Y. Xiong, BTB protein Keap1 targets antioxidant transcription factor Nrf2 for ubiquitination by the Cullin 3-Roc1 ligase, Mol. Cell. Biol. 25 (2005) $162-171$.

[155] A.L. Eggler, E. Small, M. Hannink, A.D. Mesecar, Cul3-mediated Nrf2 ubiquitination and antioxidant response element (ARE) activation are dependent on the partial molar volume at position 151 of Keap1, Biochem. J. 422 (2009) 171-180.

[156] F. Zhao, T. Wu, A. Lau, T. Jiang, Z. Huang, X.J. Wang, W. Chen, P.K. Wong, D.D. Zhang, Nrf2 promotes neuronal cell differentiation, Free Radic. Biol. Med. 47 (2009) 867-879.

[157] S. Hyeon, H. Lee, Y. Yang, W. Jeong, Nrf2 deficiency induces oxidative stress and promotes RANKL-induced osteoclast differentiation, Free Radic. Biol. Med. 65 (2013) 789-799.

[158] H. Kanzaki, F. Shinohara, M. Kajiya, T. Kodama, The Keap1/Nrf2 protein axis plays a role in osteoclast differentiation by regulating intracellular reactive oxygen species signaling, J. Biol. Chem. 288 (2013) 23009-23020.

[159] S. Murakami, R. Shimizu, P.H. Romeo, M. Yamamoto, H. Motohashi, Keap1-Nrf2 system regulates cell fate determination of hematopoietic stem cells, Genes Cells 19 (2014) 239-253.

[160] B. Meusser, C. Hirsch, E. Jarosch, T. Sommer, ERAD: the long road to destruction, Nat Cell Biol. 7 (2005) 766-772.

[161] P. Walter, D. Ron, The unfolded protein response: from stress pathway to homeostatic regulation, Science 334 (2011) 1081-1086.

[162] M.W. Pellegrino, A.M. Nargund, C.M. Haynes, Signaling the mitochondrial unfolded protein response, Biochim. Biophys. Acta 1833 (2013) 410-416.

[163] J.P. DeLany, Z.E. Floyd, S. Zvonic, A. Smith, A. Gravois, E. Reiners, X. Wu, G. Kilroy, M. Lefevre, J.M. Gimble, Proteomic analysis of primary cultures of human adiposederived stem cells: modulation by adipogenesis, Mol. Cell. Proteomics 4 (2005) 731-740.

[164] M. Hernebring, G. Brolén, H. Aguilaniu, H. Semb, T. Nyström, Elimination of damaged proteins during differentiation of embryonic stem cells, Proc. Natl. Acad. Sci. U. S. A. 103 (2006) 7700-7705.

[165] M. Hernebring, Å. Fredriksson, M. Liljevald, M. Cvijovic, K. Norrman, J. Wiseman, H. Semb, T. Nyström, Removal of damaged proteins during ES cell fate specification requires the proteasome activator PA28, Sci. Rep. 3 (2013) 1381-1386.

[166] Z. Cui, S.M. Hwang, A.V. Gomes, Identification of the immunoproteasome as a novel regulator of skeletal muscle differentiation, Mol. Cell. Biol. 34 (2014) 96-109.

[167] C.H. Ramaekers, B.G. Wouters, Regulatory functions of ubiquitin in diverse DNA damage responses, Curr. Mol. Med. 11 (2011) 152-169.

[168] A.B. Robertson, A. Klungland, T. Rognes, I. Leiros, DNA repair in mammalian cells: base excision repair: the long and short of it, Cell. Mol. Life Sci. 66 (2009) 981-993.

[169] N. Gurusamy, S. Mukherjee, I. Lekli, C. Bearzi, S. Bardelli, D.K. Das, Inhibition of ref-1 stimulates the production of reactive oxygen species and induces differentiation in adult cardiac stem cells, Antioxid. Redox Signal. 11 (2009) 589-600.

[170] K. Asagoshi, K. Tano, P.D. Chastain II, N. Adachi, E. Sonoda, K. Kikuchi, H. Koyama, K. Nagata, D.G. Kaufman, S. Takeda, S.H. Wilson, M. Watanabe, J.A. Swenberg, J. 
Nakamura, FEN1 functions in long patch base excision repair under conditions of oxidative stress in vertebrate cells, Mol. Cancer Res. 8 (2010) 204-215.

[171] Z. Guo, J. Kanjanapangka, N. Liu, S. Liu, C. Liu, Z. Wu, Y. Wang, T. Loh, C. Kowolik, J. Jamsen, M. Zhou, K. Truong, Y. Chen, L. Zheng, B. Shen, Sequential posttranslational modifications program FEN1 degradation during cell-cycle progression, Mol. Cell 47 (2012) 444-456.

[172] J. White, S. Dalton, Cell cycle control of embryonic stem cells, Stem Cell Rev. 1 (2005) 131-138.

[173] T. Yao, L. Song, J. Jin, Y. Cai, H. Takahashi, S.K. Swanson, M.P. Washburn, L. Florens, R.C. Conaway, R.E. Cohen, J.W. Conaway, Distinct modes of regulation of the Uch37 deubiquitinating enzyme in the proteasome and in the Ino80 chromatinremodeling complex, Mol. Cell 31 (2008) 909-917.

[174] L. Wang, Y. Du, J.M. Ward, T. Shimbo, B. Lackford, X. Zheng, Y.L. Miao, B. Zhou, L. Han, D.C. Fargo, R. Jothi, C.J. Williams, P.A. Wade, G. Hu, INO80 facilitates pluripotency gene activation in embryonic stem cell self-renewal, reprogramming, and blastocyst development, Cell Stem Cell 14 (2014) 575-591.
[175] D.A. Liebermann, B. Gregory, B. Hoffman, AP-1 (Fos/Jun) transcription factors in hematopoietic differentiation and apoptosis, Int. J. Oncol. 12 (1998) 685-700.

[176] S. Dalton, Signaling networks in human pluripotent stem cells, Curr. Opin. Cell Biol. 25 (2013) 241-246.

[177] J.W. Cheng, Z. Sadeghi, A.D. Levine, M.S. Penn, H.A. von Recum, A.I. Caplan, A. Hijaz, The role of CXCL12 and CCL7 chemokines in immune regulation, embryonic development, and tissue regeneration, Cytokine 69 (2014) 277-283.

[178] S.K. Law, C.S. Leung, K.L. Yau, C.L. Tse, C.K. Wong, F.P. Leung, L. Mascheck, Y. Huang, H. Sauer, S.Y. Tsang, Regulation of multiple transcription factors by reactive oxygen species and effects of pro-inflammatory cytokines released during myocardial infarction on cardiac differentiation of embryonic stem cells, Int. J. Cardiol. 168 (2013) 3458-3472.

[179] H.Y. Yang, D.K. Jeong, S.H. Kim, K.J. Chung, E.J. Cho, U. Yang, S.R. Lee, T.H. Lee, The role of peroxiredoxin III on late stage of proerythrocyte differentiation, Biochem. Biophys. Res. Commun. 359 (2007) 1030-1036. 